\title{
Challenges in the surgical pathological diagnosis of breast cancer
}

\author{
Ph. D. Thesis \\ TAMÁS ZOMBORI, M.D.
}

Szeged, Hungary

2018 


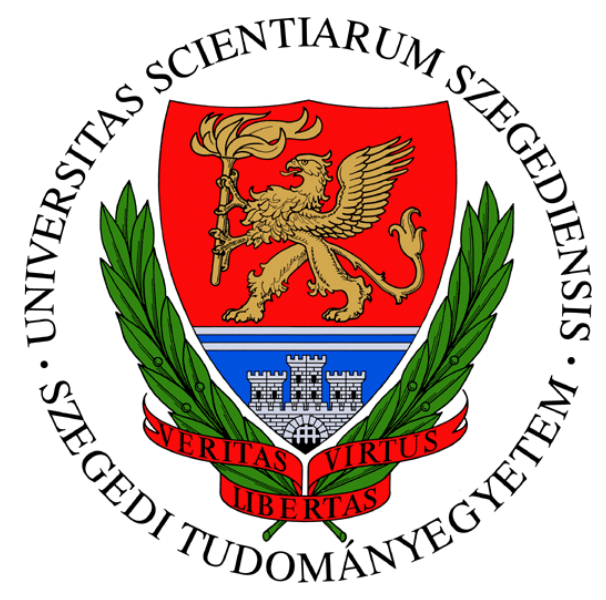

\title{
Challenges in the surgical pathological diagnosis of breast cancer
}

\author{
Ph. D. Thesis
}

\section{TAMÁS ZOMBORI, M.D.}

\author{
Supervisor: \\ Gábor Cserni, M.D. D.Sc. \\ Department of Pathology \\ Doctoral School of Multidisciplinary Medical Scienses \\ University of Szeged \\ Szeged, Hungary
}




\section{LIST OF FULL PAPERS THAT SERVED AS THE BASIS OF THE PH.D. THESIS}

I. Zombori T, Cserni G. Immunohistochemical analysis of the expression of breast markers in basal-like breast carcinomas defined as triple negative cancers expressing keratin 5. Pathol Oncol Res. 2018;24:259-267. doi: 10.1007/s12253-017-0246-y.

IF: 1.93

II. Cserni G, Zombori T, Andreu X, Bianchi S, Regitnig P, Amendoeira I, Balmativola D, Kovács A, Cordoba A, Reiner A, Kulka J, Kaya H, Liepniece-Karele I, Quinn C, Kővári B. Is regression after neoadjuvant chemotherapy for locally advanced breast cancer different in sentinel and non-sentinel nodes? Pathol Oncol Res. 2018;24:167-170. doi: 10.1007/s12253017-0229-z.

IF: 1.93

III. Zombori T, Cserni G. Elastic stains in the evaluation of DCIS with comedo necrosis in breast cancers. Virchows Arch. 2018;472:1007-1014. doi: 10.1007/s00428-017-2259-z.

IF: 2.93

IV. Zombori T, Cserni G. Patterns of regression in breast cancer after primary systemic treatment. Pathol Oncol Res. [under consideration]

\section{OTHER PUBLICATIONS}

V. Janovszky Á, Szabó A, Varga R, Garab D, Boros M, Mester C, Beretka N, Zombori T, Wiesmann HP, Bernhardt R, Ocsovszki I, Balázs P, Piffkó J. Periosteal microcirculatory reactions in a zoledronate-induced osteonecrosis model of the jaw in rats. Clin Oral Investig. 2015;19:1279-88. doi: 10.1007/s00784-014-1347-6.

IF: 2.38

VI. Zombori T, Furák J, Nyári T, Cserni G, Tiszlavicz L. Evaluation of grading systems in stage I lung adenocarcinomas: a retrospective cohort study. J Clin Pathol. 2018;71:135-140. doi: 10.1136/jclinpath-2016-204302.

IF: 2.89 
VII. Zombori T, Lehóczky L, Cserni B, Nyári T, Cserni G. [Evaluation of anatomic and prognostic stages of breast cancer according to the 8th edition of the TNM staging system Retrospective analysis based on data from deceased patients once diagnosed with breast cancer]. Orv Hetil. 2017;158:1373-1381. doi: 10.1556/650.2017.30849. [Hungarian]

IF: 0.32

VIII. Maráz R, Zombori T, Ambrózay É, Cserni G. The role of preoperative axillary ultrasound and fine-needle aspiration cytology in identifying patients with extensive axillary lymph node involvement. Eur J Surg Oncol. 2017;43:2021-2028. doi:

10.1016/j.ejso.2017.08.007.

IF: 3.68

IX. Vöröslakos M, Takeuchi Y, Brinyiczki K, Zombori T, Oliva A, Fernández-Ruiz A, Kozák G, Kincses ZT, Iványi B, Buzsáki G, Berényi A. Direct effects of transcranial electric stimulation on brain circuits in rats and humans. Nat Commun. 2018;9:483. doi:

10.1038/s41467-018-02928-3.

IF: 12.32

X. Zombori T, Nyári T, Tiszlavicz L, Pálföldi R, Csada E, Géczi T, Ottlakán A, Pécsy B, Cserni G, Furák J. The more the micropapillary pattern in stage I lung adenocarcinoma, the worse the prognosis-a retrospective study on digitalized slides. Virchows Arch.

2018;472:949-958. doi: 10.1007/s00428-018-2337-x.

IF: 2.93

XI. Diossy M, Reiniger L, Sztupinszki Z, Krzystanek M, Timms KM, Neff C, Solimeno C, Pruss D, Eklund AC, Tóth E, Kiss O, Rusz O, Cserni G, Zombori T, Székely B, Tímár J, Csabai I, Szallasi Z. Breast cancer brain metastases show increased levels of genomic aberration-based homologous recombination deficiency scores relative to their corresponding primary tumors. Ann Oncol. 2018;29:1948-1954. doi: 10.1093/annonc/mdy216.

IF: 13.92

XII. Zombori T, Tóth N, Furák J, Berényi Z, Tiszlavicz L. [Tumor of posterior mediastinum - rare case of extramedullary myelolipoma]. Magy Seb. 2017;70:74-77. doi:

10.1556/1046.70.2017.1.11. [Hungarian.] 
TABLE OF CONTENTS

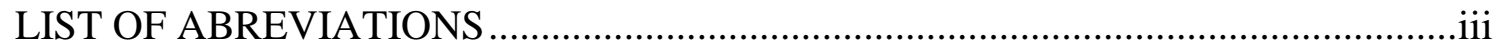

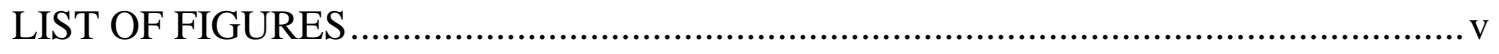

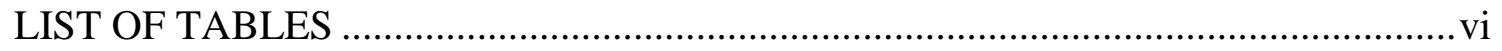

1. INTRODUCTION

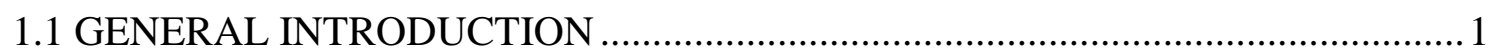

1.2. TRIPLE NEGATIVE BREAST CANCERS AS A DIAGNOSTIC CHALLENGE.3

1.3. TUMOR REGRESSION AFTER PRIMARY SYSTEMIC THERAPY IN BREAST CANCER .5

1.4. TUMOR REGRESSION AFTER PRIMARY SYSTEMIC THERAPY IN AXILLARY LYMPH NODES. . .7

1.5. BREAST WITH DIFFUSE DCIS WITH COMEDO-LIKE NECROSIS AND AMORPHOUS CALCIFICATION -THEORY OF NEODUCTGENESIS .................... 8

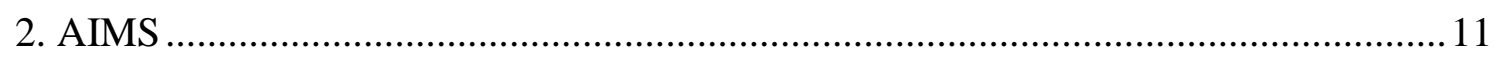

3. MATERIALS AND METHODS

3.1. IMMUNOHISTOCHEMICAL ANALYSIS OF BASAL-LIKE TNBCS. 11

3.2. EVALUATION OF REGRESSION PATTERNS IN BREAST CANCER AFTER PST

3.3. EVALUATION OF REGRESSION HETEROGENEITY IN AXILLARY LYMPH NODES AFTER PST .15

3.4. ANALYSIS OF LUMEN FORMING UNITS IN CASES OF DIFFUSE DCIS WITH COMEDO-LIKE NECROSIS AND CASTING TYPE CALCIFICATION 15

4. RESULTS

4.1. IMMUNOHISTOCHEMICAL ANALYSIS OF BASAL-LIKE TNBCS. 18

4.2. EVALUATION OF REGRESSION PATTERNS IN BREAST CANCER AFTER PST

4.3. EVALUATION OF REGRESSION HETEROGENEITY IN AXILLARY LYMPH NODES AFTER PST 26

4.4. ANALYSIS OF LUMEN FORMING UNITS IN CASES OF DIFFUSE DCIS WITH COMEDO-LIKE NECROSIS AND CASTING TYPE CALCIFICATION 


\section{DISCUSSION}

5.1. IMMUNOHISTOCHEMICAL ANALYSIS OF BASAL-LIKE TNBCS .32

5.2. EVALUATION OF REGRESSION PATTERNS IN BREAST CANCER AFTER PST 35

5.3. EVALUATION OF REGRESSION HETEROGENEITY IN AXILLARY LYMPH NODES AFTER PST 37

5.4. ANALYSIS OF LUMEN FORMING UNITS IN CASES OF DIFFUSE DCIS WITH COMEDO-LIKE NECROSIS AND CASTING TYPE CALCIFICATION 38

6. CONCLUSIONS .40

7. ACKNOWLEDGEMENTS 41

8. REFERENCES 43

9. APPENDIX

9.1. MAJOR NEW FINDINGS 62

9.2. SUPPLEMENTARY TABLES .63

9.3. MAGYAR NYELVÜ ÖSSZEFOGLALÓ 67 


\section{LIST OF ABBREVIATIONS}

AJCC:

ALND:

CK:

CS:

DCIS:

EGFR:

ER:

Erb-B2/HER-2:

FOXA:

GCDFP-15:

HE:

IHC:

MG:

MRI:

NR:

NST:

ORC:

pCR:

PHT:

PR:

PST:

RCB:

RTU:

SLN:

TDLU:

TMA:
American Joint Committee on Cancer

axillary lymph node dissection

cytokeratin

concentric shrinkage

ductal carcinoma in situ

epidermal growth factor receptor

estrogen receptor

human epidermal growth factor receptor 2

forkhead-box A1

gross cystic disease fluid protein-15

hematoxylin and eosin staining

immunohistochemical

mammaglobin A

magnetic resonance imaging

nodal regression

breast cancer of no special type

orcein staining

pathological complete regression

primary hormone therapy

progesterone receptor

primary systemic therapy

Residual Cancer Burden

ready to use

sentinel lymph node

terminal ductulolobular unit

tissue microarray 
TNBC:

triple negative breast cancer

TRL:

tumor-reactive lymphadenopathy

UICC:

Union for International Cancer Control

US:

ultrasonography

WHO:

World Health Organization 


\section{LIST OF FIGURES}

FIGURE 1. ELASTIC FIBERS AROUND NORMAL AND DILATED ANATOMIC STRUCTURES.

FIGURE 2 PATTERNS OF REGRESSION AND PECULIAR CELLULAR CHANGES (MONSTER CELLS) IN POST-TREATMENT SPECIMENS.

FIGURE 3. ANNOTATED STRUCTURES: STRUCTURES THAT COULD BE IDENTIFIED ON BOTH HEMATOXYLIN AND ORCEIN SLIDES WERE NUMBERED AND CLASSIFIED AS DUCTS (A), LIKELY DUCTS (B), UNCLASSIFIABLE STRUCTURES (C), LIKELY ACINI (D) OR ACINI (E)

FIGURE 4. ELASTIC FIBRES AROUND NORMAL AND DILATED ANATOMIC STRUCTURES .17

FIGURE 5. EXAMPLES OF NOTICEABLE (AT LEAST 5\%) GATA-3, MAMMAGLOBIN-A, GCDFP-15, NY-BR-1 AND BCA-225 STAINING ON THE LEFT (A, C, E, G, I, RESPECTIVELY) AS OPPOSED TO FOCAL AND WEAK STAINING WITH THESE MARKERS (B, D, F, H, J, RESPECTIVELY) ON THE RIGHT. ARROWS IN B INDICATE THE FEW WEAKLY STAINED NUCLEI

FIGURE 6. HIERARCHICAL LABELING OF THE TUMORS WITH 4 "BREAST SPECIFIC" MARKERS

FIGURE 7. ELASTIC FIBRES AROUND DUCTS INVOLVED BY DCIS, AND THEIR LACK AROUND SIMILAR STRUCTURES, THAT COULD REPRESENT NEODUCTS, BUT DO NOT REACH AN INDIVIDUAL SCORE FOR THE QUALIFICATION AS NEODUCT.IN A CASE NEGATIVE FOR NEODUCTGENESIS ON THE BASIS OF THE OVERALL SCORE (ORCEIN, 4X) 
LIST OF TABLES

TABLE 1. DETAILS OF THE ANTIBODIES USED FOR IMMUNOHISTOCHEMISTRY 12

TABLE 2. NEODUCTGENESIS-SCORE 18

TABLE 3. BREAST MARKER EXPRESSIONS IN THE TUMORS INVESTIGATED 19

TABLE 4. MUTUAL BREAST MARKER EXPRESSIONS IN THE TUMORS INVESTIGATED 21

TABLE 5. MORPHOLOGICAL FEATURES OF CASES EVALUATED, DISPLAYED ACCORDING TO THE MOLECULAR SUBTYPES OF BREAST CANCER 24

TABLE 6. MORPHOLOGICAL CHARACTERISTICS OF REGRESSION PATTERNS 25

TABLE 7. RELATION BETWEEN ALTERATIONS OF GRADE, THERAPY RECEIVED AND "MONSTER" CELLS, RESPECTIVELY

TABLE 8. CATEGORIZATION OF THE RESULTS ON THE BASIS OF POSSIBLE VARIATIONS IN THE DISTRIBUTION OF METASTASES AND REGRESSION AND THEIR RELATION TO SUPPORT THE THEORY OF A POSSIBLE SELECTIVE REGRESSION PATTERN IN SLNS 28

TABLE 9. THE PROPORTIONS OF ELASTIC FIBERS AROUND THE EVALUATED STRUCTURES 30

TABLE 10. THE MORPHOLOGICAL CHARACTERISTICS OF POTENTIAL NEODUCTS $(\mathrm{N}=218)$ 31

IN THE APPENDIX:

SUPPLEMENTARY TABLE 1. BASIC PATHOLOGIC FEATURES OF THE TUMORS SELECTED FOR TMA 63

SUPPLEMENTARY TABLE 2. CLINICAL CHARACTERISTICS OF PATIENTS 64 SUPPLEMENTARY TABLE 3. BASIC CLINICOPATHOLOGICAL CHARACTERISTICS OF CASES 65

SUPPLEMENTARY TABLE 4. SUMMARY OF RESULTS FROM OTHER SERIES EXPLORING THE LABELING OF TNBCS 66 


\section{INTRODUCTION}

\subsection{GENERAL INTRODUCTION}

Breast cancer remains the most frequent malignant tumor among women in Europe $[1,2]$. Organized breast cancer screening programs, the mass media, the large number of conferences on breast cancer reveal the high level of epidemiological, sociological and psychological significance of this disease.

A PubMed search revealed 369900 different papers related to breast cancer overall at the time of writing this thesis [3]. This huge number of publications reflects the degree of interest in the research on breast neoplasms.

Although breast cancer is often mentioned as a single disease in statistics, it is obvious that the term refers to several different diseases. The variegation can also be seen in the classification systems of breast neoplasms. Breast cancers can be classified based on histology, on degree of differentiation (grade), on extent and spread of tumor (stage) and on molecular profile, to mention only the most common categorizations from daily pathology practice. A common feature of these approaches is the effort to subdivide breast cancer by risk and outcome.

In the histological classification of breast neoplasms introduced by the World Health Organization (WHO) in 2012 [4], plenty of specific subtypes are defined (lobular, tubular, cribriform, mucinous, medullary carcinoma, etc.) followed by the most frequent carcinoma of no special type (NST), which does not fulfill the features of any special type. (This approach to histological typing will remain in the next edition of the WHO blue book [G. Cserni, personal communication]) Special type carcinomas are identified if a specific growth pattern takes place in more than $90 \%$ of their tumor area. Among special types, lobular carcinoma has to be underlined, as it is the second most frequently encountered one following NST, while other special types are rare [5].

As concerns the level of differentiation reflected by the histological grade, it is one of the first attempts in breast cancer pathology to predict outcome on the basis of the biology of the tumor. The Nottingham score system is widely known and used: tubule forming tendency, nuclear atypia and the mitotic rate in 10 high power fields are taken into consideration during the evaluation [5]. 
The staging system is applied for the description of the extent and spread of malignant tumors and is essential for the standardization of therapy in oncology. The two bodies maintaining most staging systems are the Union for International Cancer Control (UICC) and the American Joint Committee on Cancer (AJCC). The staging system introduced by the AJCC and the UICC has respect for the size and some specific features of the tumor (T), presence of lymph node (regional) metastasis (N) and distant metastasis (M). The stage is defined by the combinations of these categories and can be determined by physical, radiological and pathological examinations. The latter is considered to be the most specific and sensitive method to establish the stage [6;7].

Perou and coworkers evaluated gene expression in breast cancer samples and suggested a molecular classification of the disease [8]. In their original classification, basal-like, Erb-B2 (human epidermal growth factor receptor 2, HER2) overexpressing (HER2+), normal-breastlike and luminal (estrogen receptor positive, ER+) breast cancers had been identified. Gene expression profiling is the gold standard for the identification of these molecular breast cancer subtypes, but this method is not widely available. To make the classification more affordable to most pathology laboratories, immunohistochemical (IHC) profiles have been correlated to the molecular profiles. According to the IHC surrogate classification, breast carcinomas can be classified into luminal A-like (ER+ and/or progesterone receptor (PR)+ and HER2- with low proliferation), luminal B-like (ER+ and/or PR+ and either HER2+ or highly proliferating on the basis of Ki-67 labeling), HER2+ non-luminal-like (ER-, PR- and HER2+) and triplenegative breast cancers (TNBC; ER-, PR- and HER2-). The latter group can be subclassified into basal-like TNBC (keratin (CK) 5/6+ and/or epidermal growth factor receptor, EGFR+) and non-basal-like TNBC (CK 5/6- and EGFR-) [9]. This molecular classification provides so valuable additional information about prognosis and appropriate treatment selection, that beside the anatomical stages based on TNM, novel prognostic stages were introduced in the $8^{\text {th }}$ edition of the AJCC staging system [6;10]. The latter include the traditional TNM categories and biomarkers referring to molecular subtypes.

The modalities of systemic therapy are different according to molecular subtypes. There are targeted pharmaceutics against the ER-pathway and the HER-2 mediated pathway in cases of hormone receptor positive breast cancers and HER-2-enriched neoplasms. The TNBCs are unsuitable for these therapeutic regimes, in their cases systemic chemotherapy (e.g. anthracycline and taxane, taxane and/or platinum derivates) is required. In cases of advanced 
cancer, primary systemic therapy (PST) or primary hormone therapy (PHT) is utilized in order to reduce the tumor mass and increase the possibility of operability.

In our work, we focused on immunophenotyping of TNBCs, on effects of primary systemic therapy (PST) in the tumor bed and in the axillary lymph nodes, and on cases having diffuse ductal carcinoma in situ (DCIS) with comedo-like necrosis and amorphous calcification, which are potential cases of neoductgenesis.

\subsection{TRIPLE NEGATIVE BREAST CANCER AS A DIAGNOSTIC CHALLENGE}

Metastases of breast cancer develop through either the lymphatic or the blood vessels, and affect regional lymph nodes and distant organs, including the lungs, the liver, bones, and the brain. Since the lifetime risk of developing cancer is about one out of three women [11], second primaries are not rare, and must be separated from metastases of a known breast cancer. Sometimes, metastasis is the first clinical sign of an unknown primary breast cancer. In case of metastatic carcinoma, it is essential to prove its metastatic nature and origin.

Despite their less than perfect specificity, ER, PR and HER2 are among the most useful IHC markers for suggesting breast origin. These antibodies can be helpful in cases of luminal Alike, luminal B-like and HER2+ subtypes, but not in cases of TNBC which represent approximately $15 \%$ of all breast cancers [12]. Without the information of a previous primary breast carcinoma, and because of its phenotypic overlap with other potential primaries, a triple negative case can easily confuse the pathologist. Several immunomarkers as GATA-3, mammaglobin A (MG), gross cystic disease fluid protein-15 (GCDFP-15) and NY-BR-1 have been studied recently to verify the breast origin in metastatic cancer.

GATA-3 is a transcription factor with role in cell proliferation and differentiation of breast luminal epithelial cells. GATA3 is involved in T-cell-specific cell regulation, in the development of the skin and its adnexal structures and in carcinomas [13, 14]. Previously, GATA-3 was thought to be a specific marker of breast and urothelial origin, but recent studies have shown its presence in squamous carcinoma of the skin, lung, uterine cervix, vulva, larynx and anus, salivary gland tumors, basal cell carcinoma, apocrine carcinoma, skin adnexal tumors, Brenner tumor, mesothelioma, chromophobe renal cell carcinoma, pancreatic adenocarcinoma, germ cell tumors and paraganglioma [15-18]. GATA3 and ER are closely associated and involved in a positive cross-regulatory loop. This explains the positive correlation between GATA3 and ER expression in breast cancers [19; 20]. Although some studies have suggested a prognostic or predictive role for GATA3 expression [21-24], it can 
also be viewed as a marker to prove the mammary origin of metastatic cancer. According to reports, the expression frequency of GATA-3 ranges from $47 \%$ to $100 \%$ among all breast adenocarcinomas $[16 ; 17 ; 19 ; 25-28]$.

MG was described by Watson et al. in 1997 as a $10.5 \mathrm{kD}$ secretory protein that shares homology with the uteroglobin family [29]. The gene of MG is located at 11q13, which is frequently amplified in breast carcinoma [30]. MG is generally positive in normal breast epithelium. Besides breast carcinomas, several tumors express MG, like endometrial carcinoma, sweat gland tumors, gastric, pulmonary, colonic and ovarian tumors and some melanomas [31-36]. The overall expression rate among all breast carcinomas is approximately $80 \%[29 ; 31 ; 32 ; 34 ; 37-39]$.

GCDFP-15 (or BRST-2) was detected in breast gross cystic disease fluid by Haagensen et al. in 1977. The monomer of GCDFP-15 has a molecular weight of $15 \mathrm{kD}$ [40]. Its gene region was found on chromosome 7. GCDFP-15 is normally present in apocrine metaplasia of the breast and its presence has been described in salivary and sweat gland tumors and prostatic carcinomas [41]. The reported expression frequency of GCDFP-15 ranges from 25\% to 85\% among all breast adenocarcinomas [31; 32; 38; 39; 41; 42].

NY-BR-1, a differentiation antigen of mammary tissue was first described by Jäger et al in 2001 [43]. Bioinformatic analysis has revealed that NY-BR1 has a DNA-binding site followed by a leucine zipper motif, therefore it could be a transcription factor. Due to its five ankyrin tandem repeats, it may have a role in protein-protein interactions, as well [43]. It has been detected in the epithelial cells of mammary ducts and lobules and in normal testis. One third of sweat gland tumors [44] showed positivity with NY-BR1. Although NY-BR-1 positivity was demonstrated in a case of vulvar phyllodes tumor [45], there is no other normal or tumor tissue which has been reported to express this protein, therefore NY-BR-1 appears to be a breast-specific protein. In invasive breast carcinomas, the range of NY-BR-1 expression has been reported between $46.6 \%$ and $70 \%$, showing a strong association with ER and lowergrade carcinomas [44; 46-51].

BCA-225 is a glycoprotein with a molecular weight between $225.000-250.000 \mathrm{kD}$. It was first identified by Mesa-Tejada and coworkers in 1988 [52]. Although it was previously described as a specific immunomarker of breast carcinoma, a later study by Loy and associates concluded that BCA-225 is commonly expressed in human adenocarcinomas of different origins, and is therefore not specific for the breast [53]. BCA-225 expression was often 
present in adenocarcinomas of the breast (98\%), kidney (94\%), ovary (80\%), lung (74\%) and intermediate expression rates (36\%-68\%) were found in adenocarcinomas of the prostate, bile ducts, thyroid, endometrium, endocervix and pancreas [53].

Although the mentioned "breast markers" have been tested in several series of breast carcinomas, only a few cases of TNBC have been assessed for them. TNBC also constitute a heterogeneous group of breast carcinomas, and basal-like carcinomas have not been specifically investigated for the expression of the above markers.

\subsection{TUMOR REGRESSION AFTER PRIMARY SYSTEMIC THERAPY IN BREAST}

\section{CANCER}

PST of breast cancer has become more frequent recently. This approach to systemic treatment is currently applied in bulky ( $>2 \mathrm{~cm}$ ) tumors or locally advanced cancers [54]. The radiologic and pathologic interpretation of regression is sometimes controversial due to some mismatch between the entities used for assessment. There is no internationally agreed consensus on how different imaging modalities should be prioritized and specimen handling is also rather heterogeneous.

The presence or absence of regression is evaluated by radiologic modalities, namely ultrasonography (US), mammography and magnetic resonance imaging (MRI). This examination influences the continuation, shift or termination of PST and the multidisciplinary decision about surgical treatment. After the operation, the pathological examination reveals the degree of regression: pathological complete regression (pCR) on one end, and the complete lack of regression on the other end of the spectrum. The scale of regression affects further treatment decisions. Therefore, a standard approach to the evaluation of the breast specimen is crucial. To reach this aim, national guidelines have been developed in individual countries like Australia [55], Belgium [56], Germany [57], the United Kingdom [58], the Netherlands [59], the United States [60] and Hungary [61].

Despite these guidelines or reviews $[62 ; 63]$ aiming at some uniformity in breast cancer reporting, there are several inconsistencies, namely in specimen work-up, definition of pCR, patterns and grades of regression.

After PST, the identification of the tumor bed may be difficult because the tumor may have become less firm, and less well circumscribed. Therefore, gross examination must be correlated with the clinical and especially radiological localization to ensure that the correct 
area is sampled. Systematic sampling should include the grossly visible tumor bed or the location of clip markers and neighboring areas to incorporate the area involved by carcinoma before treatment [63]. Digital photos, specimen mammography images or drawings should be taken for helping the comparison between clinical and morphological findings. Histopathological evaluation is based on sampling: representative areas are chosen for tissue blocks during grossing, and a tissue section represents about one thousandth of the whole thickness of the tissue block. It is obvious, that the more thorough the sampling, the more details one can discover under the microscope, especially in non-homogeneous lesions.

In case of inhomogeneous, scattered focal regression, the assessment of tumor size may be problematic, as well. The dimension of the largest invasive focus may deviate from the largest dimension of the residual tumor affected area in the tumor bed (i.e. the extent) [64].

According to the United States' Food and Drug Administration (FDA), 'Pathological complete response is defined as the absence of residual invasive cancer (ypT0ypN0 or ypTisypN0) on evaluation of the complete resected breast specimen and all sampled regional lymph nodes following completion of neoadjuvant systemic therapy' [65].The AJCC has endorsed the same definition [6]. This recommendation is based on the findings of the Collaborative Trials in Neoadjuvant Breast Cancer project. In this study, there was no difference in event-free and overall survival of patients having ypT0ypN0 or ypTisypN0 breast cancer [66]. On the contrary, the German and Austrian Breast Groups demonstrated significant worsening in event-free survival of ypTisypN0 versus ypT0ypN0 breast cancer cases [67]. Therefore, an alternative definition of complete response was proposed by this group, which excludes both residual DCIS and invasive carcinoma in the breast (ypT0ypN0 only).

Regression and its scale can be characterized by different parameters, like the size of residual invasive carcinoma, lymph node status, tumor cellularity, tumor grade, proportion of tumor remaining in breast (\%) and finally the size of tumor bed in two dimensions. Several regression grading systems based on these parameters have been introduced and validated, including those described by Miller and Payne [68], Pinder [69], Denkert and Sinn [70] and Sataloff [71].

Another feature of response to neoadjuvant therapy is homogeneity or heterogeneity of the regression. According to Provenzano and coworkers, the patterns of residual disease are 
the following: homogenous regression (cellularity decreased, size unchanged), inhomogeneous regression (cellularity decreased, size variable, small areas without residual disease), scatter pattern (cellularity decreased, size variable, tumor bed slides without residual disease) and concentric shrinkage (CS) (size decreased, cellularity similar) [63]. Especially the "scatter pattern" may lead to diagnostic pitfalls if not systematically sampled.

Not only the size and cellularity change following PST, but grade may also be altered. After PST, bizarre and/or macronucleated neoplastic giant cells may sometimes be found in the tumor bed. These cells are generally attributed to the effects of chemotherapy. The presence of these bizarre cells may increase the post-treatment grade, whereas a reduction in the proliferating cells may decrease it.

\subsection{TUMOR REGRESSION AFTER PRIMARY SYSTEMIC THERAPY IN AXILLARY LYMPH NODES}

Lymph nodes are not identical. The sentinel lymph nodes (SLN) are the first lymph nodes draining the lymph from an anatomical site and therefore, in case of a cancer in the given area, the SLNs are the first involved during the lymphatic spread of cancer. The non-SLNs of the same anatomic region develop metastases only subsequently. Development of metastasis is not the only change known to occur in tumor draining lymph nodes. Tumor-reactive lymphadenopathy (TRL) is a complex reaction of lymph nodes, which develops before the arrival of the metastatic tumor cells and comprises morphological and functional changes. Enlargement of the tumor draining lymph nodes (also induced by needle biopsy of the primary cancer) has helped axillary four-node sampling [72], and may explain the possible overlap of axillary node samples and sentinel nodes [73]. As concerns the morphological alterations, previous publications found increased total number of functional blood vessels and lymphatic vessels/sinuses in tumor draining lymph nodes. Furthermore, some authors have described dilation of functional blood vessels with structural remodeling and endothelial cell proliferation of high endothelial venules [74]. Functional changes, such as increased blood perfusion and immunological differences, like the alterations in CD28 and CD3 $\zeta$ expression of CD4+ and CD8+ T-lymphocytes [75; 76] or the reduction in density and dendritic complexity of antigen presenting paracortical dendritic cells [77] were also observed in tumor draining lymph nodes. Tumor-induced immune modulation of the SLNs versus the non-SLNs seems to act in favor of a reduced anti-tumoral immune reaction [78]. 
The above-mentioned factors may hypothetically alter the neoadjuvant therapy induced reactions in tumor-draining SLNs compared to lymph nodes without direct connection with the primary carcinoma, i.e. non-SLNs. Enhanced blood flow and enriched vasculature may increase the load of chemotherapeutics or targeted cancer therapy agents (e.g. hormone receptor modulators or trastuzumab) in lymph nodes developing TRL. A preferential regression in SLNs might influence the false negative rate of SLN biopsy after PST, by resulting in complete regression in SLNs with remaining tumor burden in non-SLNs. Alternatively, an immunosuppressed status of the SLNs as compared to non-SLNs could lead to less effect from cytotoxic therapeutics. A selective regression or non-regression may also alter the staging effect of the removal of radioactive seed localized nodes that proved to be positive before the initiation of primary systemic treatment [78].

\subsection{BREAST WITH DIFFUSE DCIS WITH COMEDO-LIKE NECROSIS AND}

\section{AMORPHOUS CALCIFICATION -THEORY OF NEODUCTGENESIS}

Breast parenchyma is organized into anatomic units corresponding to mammary lobes. A lobe can be defined as the complex of a lactiferous duct branching into smaller and smaller ducts with terminal ductules and the lobule forming acini belonging to these ductules at the end; i.e. each lactiferous duct defines a different lobe, of which 15 to 25 make up the breast parenchyma [79]. An easy to imagine visual analogy of the lobar organization would be that of a tree, where the lactiferous duct would correspond to the trunk, the ducts to branches, and the lobules to compound leaves. The outer myoepithelial layer and the basement membrane around the ducts would represent the bark of the tree. Acini of the lobules and ducts are easy to distinguish from each other. However, when their lumen enlarges and the diameter becomes larger, ectatic ducts and cystically dilated acini are not always easy to separate. The maintained lobular architecture, multiplicity of the lumens and the common presence of apocrine epithelium helps to identify dilated lumina as cysts. In contrast to cysts, ectatic ducts are generally single or separated from each other by normal breast adipose or fibrous tissue more in keeping with interlobular stroma than with intralobular stroma. Although both the ducts and lobules feature an outer myoepithelial cell layer and a basement membrane, there is usually also an elastic layer around the ducts, which is missing around the acini (Fig 1). This phenomenon can also help in the distinction between ectatic ducts or cystic acini, although the amount of elastic fibers around dilated ducts is dependent on the amount initially present and any damage by inflammatory processes (Fig 1) [80]. 
When DCIS develops in the ductal tree or its end, the terminal ductulolobular unit (TDLU), there is often a dilatation of the normal anatomic structures. When the anatomy of the breast is maintained, DCIS can easily be identified as involving the ducts and sometimes the lobules. The latter phenomenon has been called cancerisation of lobules or lobular cancerisation [81; 82] (Fig 1B). The analogy of the tree also applies to this presentation.

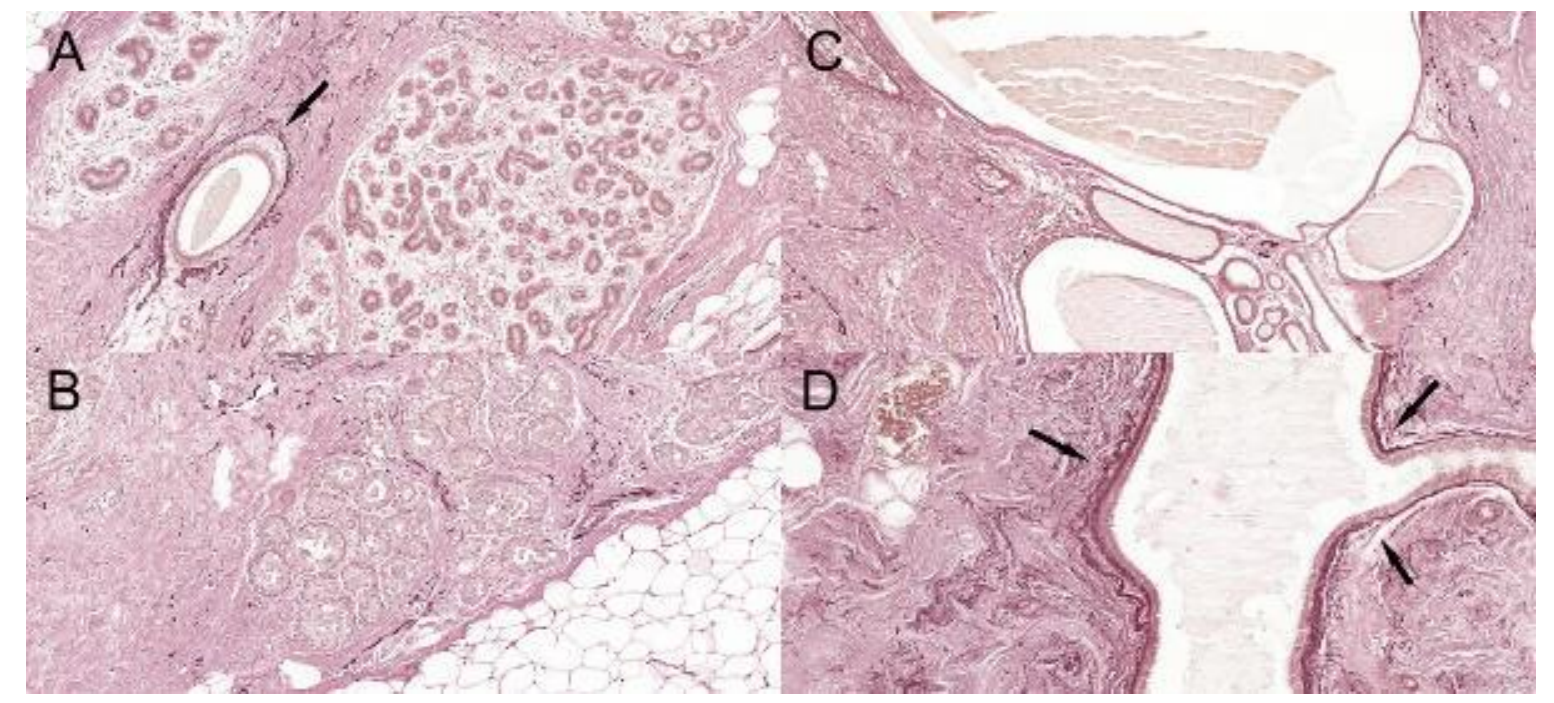

Figure 1. Elastic fibers around normal and dilated anatomic structures A: A duct with elastic coating (arrow) and acini arranged into lobules without an outer elastic layer. B: Lobular cancerisation. DCIS extending into a lobule without altering the lack of elastic fibers around lobule forming acini. C: Closely packed cysts devoid of elastic fibers. D: Ectatic duct with maintained elastic coating (arrows). (Orcein, 10x, 10x, 8x, 15x)

Some forms of DCIS do not follow this regular growth and intraluminal spread. Instead, there are plenty of more or less dilated lumens dispersed with a relatively uniform and higher than normal density. Although some believe that this pattern is also due to abnormal extent of dilatation of pre-existing structures (i.e. ducts and lobules) like overinflated balloons touching each other, there is apparently no obviously discernible lobular architecture maintained. The concept of neoductgenesis has been introduced to explain the morphology of these cancers $[83 ; 84]$. This concept suggests that new ducts are formed from the pre-existing ones and grow into the stroma. Keeping the analogy of the tree, this would correspond to new lateral branches starting to grow from the trunk or other larger branches, keeping the characteristic feature of branches, i.e. having their bark. Indeed, the structures identified under the microscope in such cases have a myoepithelial layer and a basement membrane, and are easy to interpret as DCIS, although myoepithelial phenotype and myoepithelial marker expression may be altered $[85 ; 86]$. Newly formed ducts "invade" the 
stroma in a pushing manner without losing their myoepithelial and basement membrane layers which are the diagnostic hallmark of in situ carcinomas and the clue used to exclude the presence of invasion in breast pathology. This controversy is certainly the cause why the concept of neoductgenesis is not widely accepted, despite having more and more advocates. Neoductgenesis could explain the aggressive behavior of tumors with this phenomenon having minor areas of classical invasive carcinoma of no special type (interpreted as ductal carcinomas with extensive intraductal component). Such tumors have a larger whole tumor size (including the DCIS morphology) than invasive tumor size (including only the smaller classical invasive carcinoma), and when stratified according to other prognosticators, their survival curves match those of no special type invasive carcinomas of which the size corresponds to the whole tumor size of tumors with neoductgenesis rather than their classical invasive tumor size $[83 ; 84]$. The phenomenon could also be an explanation for the anecdotal cases where no classical invasive tumor is identified near DCIS with features of neoductgenesis, but the patient dies of breast cancer [84]. Local recurrence rates in cases diagnosed as representing pure DCIS are also higher in neoplasms with proposed neoductgenesis, and this is also related to their greater extension and diffuse growth pattern [87; 88], but also reflects a worse overall prognosis.

Neoductgenesis is not easy to define. It has been associated with casting (linear branching) type calcifications on the mammogram, and tumors with this manifestation have been reported to have poor outcome in several series [83; 89-92] with some contradicting results in others [93-95]. Tenascin expression has been demonstrated around the newly formed ducts [83; 84]. Morphologic criteria have also been proposed on the basis of duct concentration, periductal fibrosis and lymphocytic infiltration [96] and may help to identify cases with this phenomenon even on histological slides. 


\section{AIMS}

The aims of the present thesis are listed as follows:

To look at the IHC staining of GATA-3, MG, GCDFP-15, NY-BR-1 and BCA-225 in a series of TNBCs showing CK5 expression and therefore being consistent with a basal-like phenotype on the basis of the IHC-based surrogate molecular classification.

To evaluate the response patterns in breast cancers after PST, focusing on correlations of radiological and pathological tumor sizes, regression heterogeneity in the tumor bed and in the axilla in different molecular subtypes of breast cancer, cellularity changes between biopsy and resection specimen, correlation between cellularity and size alterations and the incidence of macronucleated, bizarre neoplastic cells related to therapy.

To evaluate the differences in the degree of regression induced by neoadjuvant therapy in the SLNs (tumor draining lymph nodes) and in non-SLNs (non-tumor draining lymph nodes) in a series of patients who underwent SLN biopsy and axillary lymph node dissection (ALND) following neoadjuvant systemic therapy for breast cancer.

To analyze lumen forming structures of the DCIS component of a few tumors (some of which were believed to represent DCIS with neoductgenesis) with orcein staining to see how ducts and acini maintain their staining when involved by DCIS, and to see how ducts believed to be newly formed behave with this stain.

\section{MATERIALS AND METHODS}

\subsection{IMMUNOHISTOLOGICAL EVALUATION OF BASAL-LIKE TNBCS}

Invasive breast carcinomas operated on at the Bács-Kiskun County Teaching Hospital, Kecskemét between August 2005 and August 2015 and fulfilling the criteria of TNBC and CK5 positivity by IHC were selected for tissue microarray (TMA) construction. All of the specimens were fixed in $10 \%$ neutral buffered formalin for at least 24 hours. Only cases with more than 3 paraffin blocks available were used; otherwise the cases represent a consecutive series of such tumors. ER, PR, HER-2 and CK5 IHC results were obtained from the histopathology reports. 
The TMAs were constructed from archived paraffin-embedded blocks using a TMA builder device (Histopathology Ltd, Pécs, Hungary). Each TMA contained 20 tumor tissue cores, 2 $\mathrm{mm}$ in diameter. These were arranged in 5 rows and 4 columns and an additional row contained 2 non-mammary control tissues for orientation and identification purposes. Each carcinoma was represented in duplicate in 2 different TMAs, and the areas sampled were preferentially from the edge of the tumors. Care was taken to include minor amounts of normal paratumoral breast tissue in each TMA to serve as internal controls for the IHC reactions.

IHC for GATA-3, MG, GCDFP-15, NY-BR-1 and BCA-225 was performed using the antibodies and details listed in Table 1. All antibodies were used on both sets of TMAs, (i.e. two 2-mm-diameter cores of each tumor), except for BCA-225, where only one set of cores (and TMAs) was immunostained. The stains were assessed by the two authors by evaluating the proportion of nuclear (GATA-3) and cytoplasmic (MG, GCDFP-15 and BCA-225) or both nuclear and cytoplasmic (NY-BR-1) labeling of tumor cells. A staining of 5\% or more cells was considered a positive result.

\begin{tabular}{|l|l|l|l|}
\hline Antibody & Source & Clone / Catalog number & Dilution \\
\hline GATA-3 & Santa Cruz, Dallas, TX & HG3-31 / sc-268 & $1: 50$ \\
\hline MG & Biocare, Concord, CA & 1A5 / PM 269 AA, H & RTU \\
\hline GCDFP-15 & Cell Marque, Rocklin, CA & 23A3 / CMC791 & $1: 200$ \\
\hline NY-BR-1 & Thermo-Fisher, Rockford, IL & NY-BR1\#2 / MS-1932-P0 & $1: 300$ \\
\hline BCA-225 & Biogenex, Fremont, CA & CU18 / AM135-5M & RTU* \\
\hline
\end{tabular}

Table 1. Details of the antibodyies used for IHC; *RTU: ready to use

The institutional ethical committee of the Bács-Kiskun County Teaching Hospital was consulted and approved this non-interventional retrospective study. The institutional data safety manager also gave approval for this study not requiring patients' identity related data.

\subsection{EVALUATION OF REGRESSION PATTERNS IN BREAST CANCER AFTER PST}

Consecutive invasive breast carcinomas treated with PST and operated on at the BácsKiskun County Teaching Hospital, Kecskemét or at the Department of Surgery, University of Szeged from 2015 through February 2018 and from 2013 through May 2018, respectively were included. Additionally some earlier cases (from between 2010-2014) collected for a previous study on PST $(n=8)$ were also included. Exclusion criteria were unavailability of slides of either the biopsy or the excision specimen and primary endocrine therapy. 
Clinical data, namely age, gender, laterality, type of surgery, pre- and posttreatment size determined by US, mammography and MRI (as available), primary systemic therapy were collected from medical charts. Pathological data including ER, progesterone receptor (PR) and HER-2 status, ypT and ypN categories [6], TR and NR tumor and node regression categories [97], pre- and posttreatment histological grade, pathological size (both the largest invasive focus and extent of the area involved by tumor, either invasive or in situ) were obtained from the histopathology reports. The immunohistochemical surrogate classification of molecular subtypes of breast carcinomas was utilized according to the 2013 St. Gallen Consensus Conference [98]. The recommendations of the American Society of Clinical Oncology were applied for the evaluation of HER-2 immunohistochemical staining [99].

Both departments have used a similar work-up methodology recommended by the 3rd Hungarian Consensus Conference on Breast Cancer [61] including radiological localization, systematic sampling and clinical-pathological correlation on multidisciplinary meetings. All hematoxylin-eosin stained tumor (bed) containing slides of biopsy and excision specimens were analyzed. The cellularity was estimated by two pathologists (TZ \& GC) both on biopsy and excision specimens. Consensus was always reached.

The tumor bed areas showing complete regression or the absence of any regression pattern were evaluated on low (4x) and medium (10x) power fields (field areas: $0.24 \mathrm{~mm}^{2}$ and $0.005 \mathrm{~mm}^{2}$, respectively). The presence of whole slides, any low power field or any medium power field showing complete response or the lack of any response were noted. Homogenous regression was defined as pCR (Fig.2A), absence of regression on all slides (Fig.2B) and uniform degree of regression on all slides (Fig.2C). Any other pattern was perceived as inhomogeneous response (Fig.2E-G). The latter included the so called "scatter pattern", the CS [69], which was identified in case of reduction of tumor size with similar cellularity (Fig.2D). The cells having enlarged cytoplasm, multiple and/or enlarged bizarre hyperchromatic nuclei with different size and shape were labeled as "monster cells" for the purpose of this study (Fig.2H-I).

The slides of axillary sentinel lymph node excisions and/or axillary lymph node dissections were reevaluated and the presence or absence of metastasis and regression were documented. If metastatic nodes were seen with and without regression, inhomogeneous axillary response was identified. 
The alteration of pre- and posttreatment cellularity and size; and the correlation between radiological (exclusively uniformly available US data) and pathological size were analyzed by the Spearman rank model. All statistical tests were one-sided, and $p<0.05$ values were considered statistically significant. We utilized the SPSS Statistics software (IBM, SSPS 22.0, Armonk, NY USA).

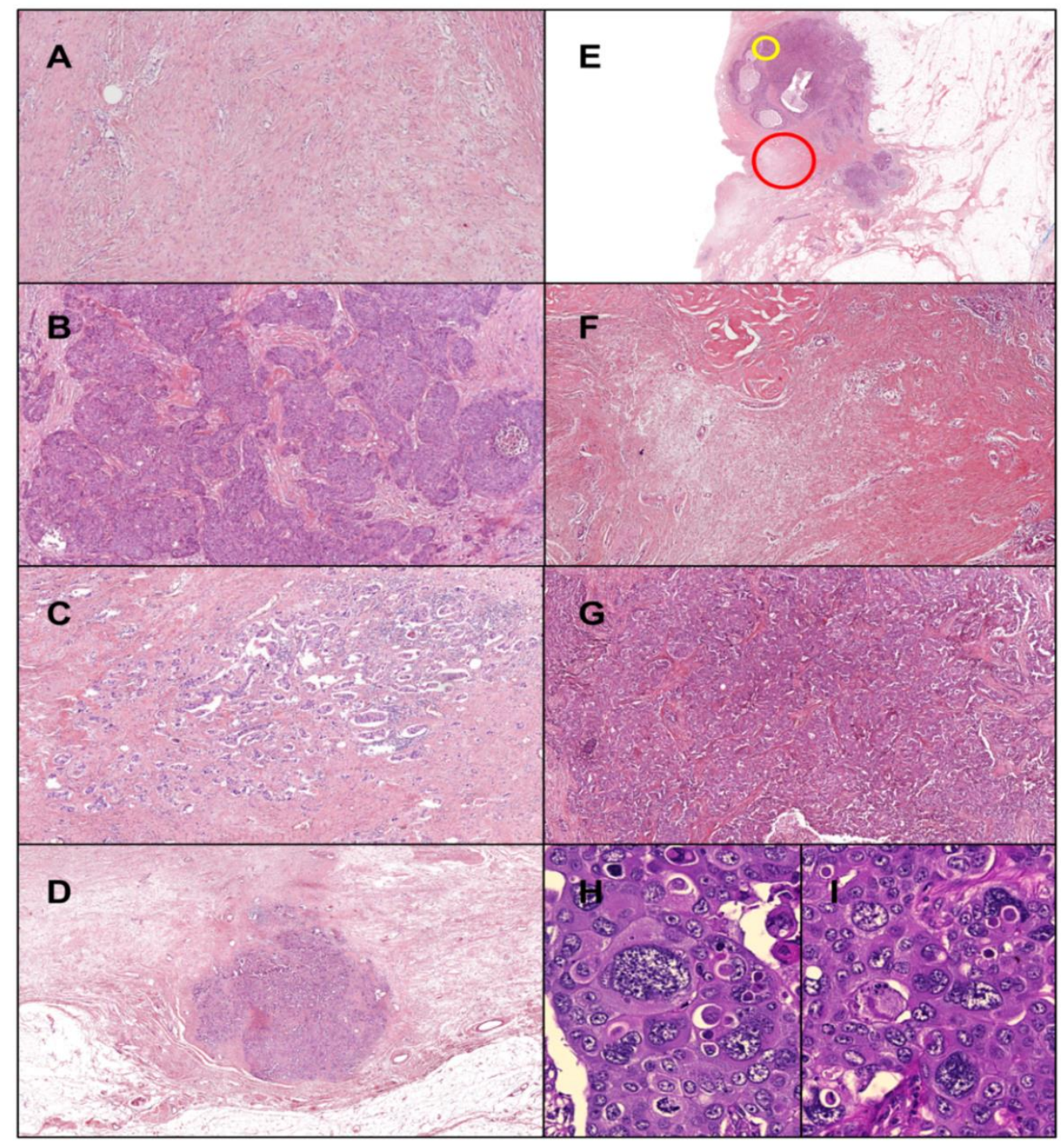

Figure 2. Patterns of regression and peculiar cellular changes (monster cells) in post-treatment specimens. A: Complete pathological regression (HE, 4x); B: Absence of any regression in the tumor bed (HE, 4x); C: Homogenous regression (HE, 4x); D: Concentric shrinkage pattern (HE, 4x); E: Inhomogeneous regression in a tumor bed. Big red circle and small yellow circle display $4 \mathrm{x}$ and 10x field area, respectively. (HE, 1x); F: 4x field area of tumor bed on "E" slide shows complete response (HE, 4x); G: 10x field area of tumor bed on "E" slide lacks any regression (HE, 10x); H and I: bizarre macronucleated "monster" cells (HE, 40x) 


\subsection{EVALUATION OF REGRESSION HETEROGENEITY IN AXILLARY LYMPH} NODES AFTER PST

In this retrospective study, lymph node tissue sections of 142 female breast cancer patients staged with SLN biopsy and ALND after receiving neoadjuvant therapy were used from the archives of the authors' institutions. Inclusion criteria for enrollment were any type of histologically verified invasive primary breast cancer treated with neoadjuvant systemic therapy, the successful identification of at least one SLN and ALND following SLN biopsy. SLNs were identified according to the routine procedure of the given institutions, and involved intra- or peritumoral or subareolar injection of a $99 \mathrm{mTc}$ labeled colloidal albumin and/or Patent blue dye in vivo. ALND was performed either routinely as part of a validation of SLN biopsy after neoadjuvant treatment or because of metastatic disease identified in the SLNs.

Tissues were fixed in buffered formalin and embedded in paraffin. Three to fourmicrometer-thick whole tissue sections were used for the standard hematoxylin-eosin staining. The presence and degree of regression were evaluated in all metastatic and non-metastatic lymph nodes, SLNs and non-SLNs separately, using the nodal regression (NR) grading recommended by the European guidelines [97]. These results were used to categorize the cases, based on whether they supported the theory that regression in SLNs may be greater than in non-SLNs or not.

No patient identity related data were required or used, disease outcome was indifferent for the study purposes, and this retrospective non-interventional setting had no influence on treatment. Such a protocol does not imply an ethical approval in most of the participating institutions, but the Ethical Committee and Data Safety Manager of Bács-Kiskun County Teaching Hospital, where the study was initiated, were consulted and no ethical concerns were raised (Reference Number: 4/170125)

\subsection{ANALYSIS OF LUMEN FORMING UNITS IN CASES OF DIFFUSE DCIS WITH COMEDO-LIKE NECROSIS AND CASTING TYPE CALCIFICATION}

Selected histological slides of patients with areas of DCIS (mostly associated with areas of invasive cancer) demonstrating comedo necrosis and central, amorphous microcalcification on histology slides were retrospectively analyzed. The study cases were from the Pathology Departments of the University of Szeged (collected from a consecutive series of patients with radiologic evidence of casting (linear branching) type calcification) and 
the Bács-Kiskun County Teaching Hospital (randomly selected cases with comedo necrosis and central amorphous calcification in the slides; these were from a previous pilot study looking at the elastic stains). The clinicopathological information needed was obtained from the radiological and histopathological reports.

Inclusion criteria were the following: casting (linear branching) type calcification described by the radiological report or the histopathology report, high or intermediate grade DCIS [100] with or without invasive breast carcinoma, resected tumor specimens and availability of slides and paraffin blocks. For control, two slides with normal breast tissue and architecture derived from random quadrant samples of tumorous cases were included in the study.

Hematoxylin and eosin (HE) staining was employed for the identification of anatomic structures involved by the in situ neoplastic cells as ducts or acini, whereas orcein staining alone or combined with hematoxylin or HE (ORC) was used for the evaluation of elastic fibers around the units previously classified on the basis of the HE stain. One or two slides per case were selected and digitized with a 3DHistec Pannoramic 250 scanner (3D Histech, Budapest, Hungary).

In the first step, with the aid of the freely downloadable Pannoramic Viewer software (3DHistec, Budapest, Hungary), the structures were numbered in parallel on both the HE and the ORC digital slides (Fig 3).

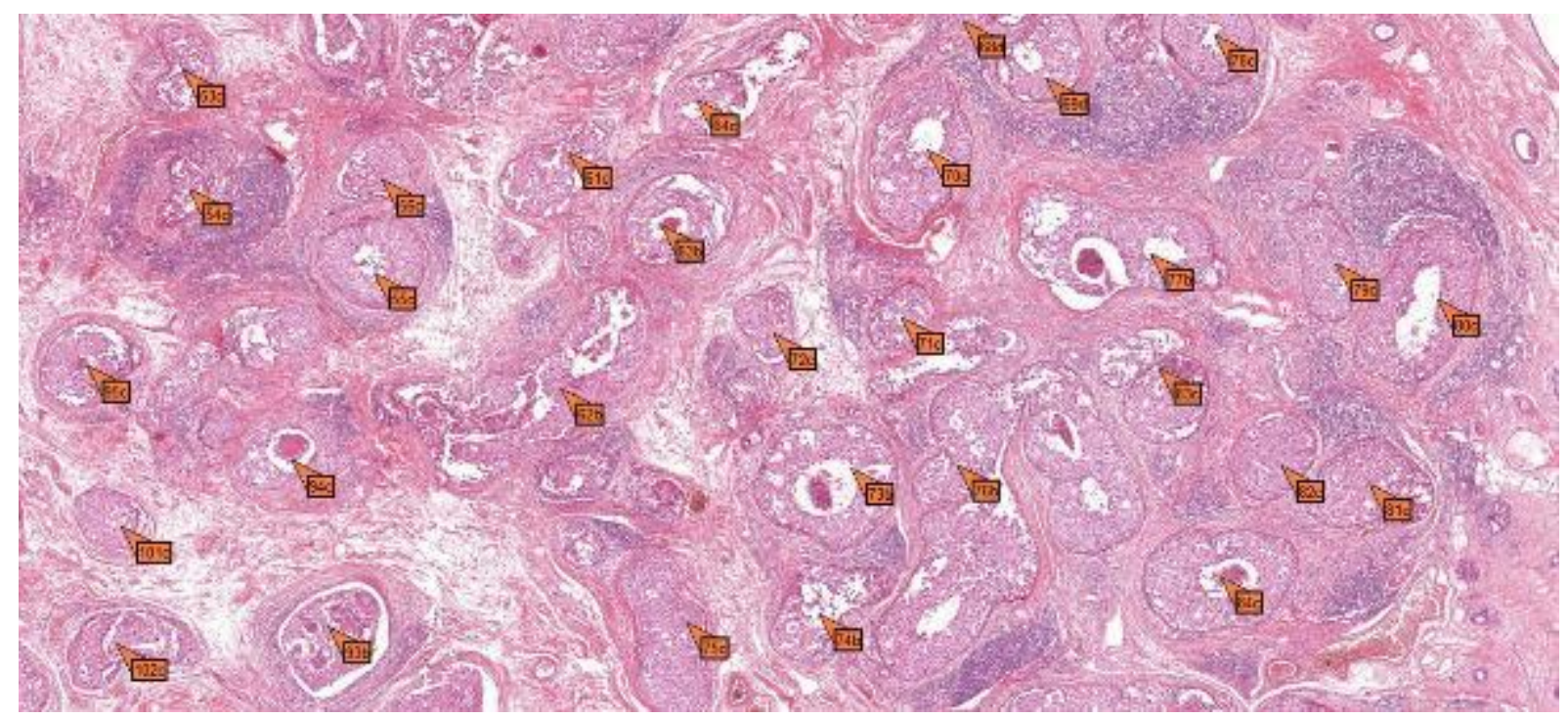

Figure 3. Annotated structures on the HE slide. (Structures that could be identified on both HE and ORC slides were numbered on both and then classified on the HE slide as ducts (a), likely ducts (b), unclassifiable structures (c), likely acini (d) or acini (e).) 
Each numbered structure that could be identified on both HE and ORC stained slides was then classified into one of the following categories: definitely representing a duct, likely to be a duct, unclassifiable, likely to be an acinus, definitely representing an acinus (Fig 3). For this classification, the resemblance to the normal microanatomical structures were considered; i.e. clustered arrangement into or resemblance to lobular structures pointing to acinar structures, and single structures pointing to a ductal nature.

The elastic fibers around the numbered and classified structures were graded as concentric presence (score 3), dominant presence (continuous or discontinuous elastic fibers around more than half of the perimeter of the structure; score 2), dominant absence (focal, elastic fibers around less than half of the perimeter of the structure; score 1) and absence of elastic fibers around the structure (score 0) (Fig 4).

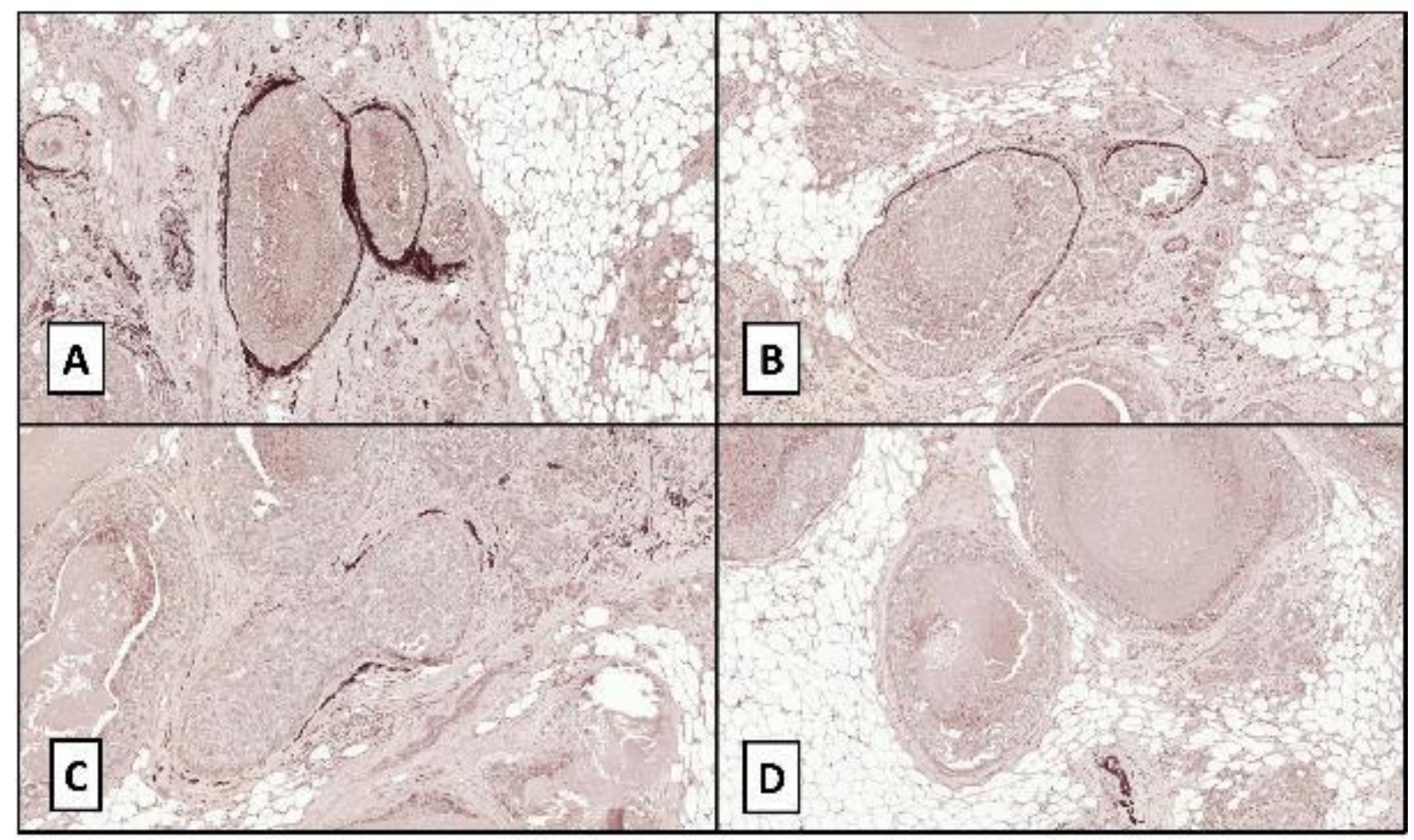

Figure 4. Elastic fibers around lumen forming units on orcein staining. A: complete circular staining; B: more than half elastic coating (rather positive), C: less than half elastic coating (rather negative); D: absence of elastic fibers

The neoductgenesis-score described by Zhou et al [96] was applied for the identification of tumors demonstrating neoductgenesis. (The cases were selected before this 
description was read). This scoring system takes into account the concentration of duct like structures and loss of normal ductal-lobular architecture, the lymphocytic infiltration and periductal fibrosis (Table 2.). The original description of the score also includes a visual scale for each score component, and this was used to label the cases. However, we also applied the score to individual structures. For this, we used the first component of the combined score from the entire slide, but the two remaining score components were derived from the lymphocytic infiltration and fibrosis around the given structure.

\begin{tabular}{|c|c|}
\hline Variable & \\
\hline \multicolumn{2}{|l|}{$\begin{array}{l}\text { Concentration of duct like structures } \\
\text { and loss of normal ductal-lobular architecture }\end{array}$} \\
\hline absent & $\mathbf{0}$ \\
\hline focal & 1 \\
\hline general & 2 \\
\hline \multicolumn{2}{|l|}{ Periductal lymphocytic infiltration } \\
\hline absent & $\mathbf{0}$ \\
\hline mild & 1 \\
\hline pronounced & 2 \\
\hline \multicolumn{2}{|l|}{ Periductal fibrosis } \\
\hline absent & $\mathbf{0}$ \\
\hline mild & 1 \\
\hline pronounced & 2 \\
\hline
\end{tabular}

Table 2. Neoductgenesis-score. Neoductgenesis identified if the sum of points is $>4$ points [96]

The statistics included the Mann-Whitney and the chi-square tests. All statistical tests were two-sided, and $p<0.05$ values were considered statistically significant. The institutional ethical committee of the Bács-Kiskun County Teaching Hospital was consulted and raised no concerns about this non-interventional retrospective study.

\section{RESULTS}

\subsection{IMMUNOHISTOCHEMICAL EVALUATION OF BASAL-LIKE TNBCS}

All markers could be evaluated in only 115 of the 118 tumors sampled, therefore the result are reported for these 115 cases. In 3 cases, the tissue cores were not evaluable due to necrosis or lack of tumor cells. The series included 4 recurrent tumors (including 1 with intramammary nodal recurrence only) and 10 cases treated with neoadjuvant systemic therapy 
with no or minimal (0-10\%) regression. The basic characteristics of these tumors are summarized in Supplementary table 1.

GATA-3 labeling was characterized by nuclear staining in the tumor cells. In a few specimens, weak nuclear staining was noted in a very small minority of lymphocytes, but this could not be confounded with either tumor cell positivity or the staining of normal mammary epithelium. MG, GCDFP-15, NY-BR-1 and BCA-225 positivity was identified as obvious cytoplasmic staining. Although the data sheet of NY-BR-1 suggests that occasional nuclear staining may occur with this antibody, this was not noted in tumor cells, but was present in a few normal breast epithelial cells. Examples of diffuse and focal IHC staining are presented in Figure 5, to demonstrate the range of positive reactions seen in the tumor samples.

The IHC results are displayed in Tables 3 and 4, which show both the proportion of tumors demonstrating any degree of staining with a given marker and the proportion considered positive according to the 5\% cut-off used in this study.

\begin{tabular}{|l|l|l|}
\hline Marker & $\begin{array}{l}\text { Any positive staining } \\
(\% ; 95 \% \text { CI }) \\
n=115\end{array}$ & $\begin{array}{l}>5 \% \text { positive staining } \\
(\% ; 95 \% \text { CI }) \\
n=115\end{array}$ \\
\hline GATA3 & $82(71.3 ; 62.4-78.7)$ & $23(20 ; 13.7-28.2)$ \\
\hline MG & $30(26.0 ; 18.9-34.8)$ & $12(10.4 ; 6.0-17.3)$ \\
\hline GCDFP-15 & $23(20.0 ; 13.7-28.2)$ & $9(7.8 ; 4.1-14.2)$ \\
\hline NY-BR-1 & $7(6.0 ; 2.9-12.0)$ & $3(2.6,0.8-7.3)$ \\
\hline BCA-225 & $74(64.3 ; 55.2-72.5)$ & $40(34.7 ; 26.6-43.8)$ \\
\hline GATA3 and MG & $21(18.2 ; 12.2-26.3)$ & $2(1.7,0.4-6.1)$ \\
\hline MG and GCDFP-15 & $12(10.4 ; 6.0-17.3)$ & $2(1.7,0.4-6.1)$ \\
\hline GATA-3, MG and GCDFP-15 & $9(7.8 ; 4.1-14.2)$ & $1(0.87 ; 0.1-4.7)$ \\
\hline NY-BR-1 and GATA-3 & $3(2.6,0.8-7.3)$ & $0(0 ; 0.0-3.1)$ \\
\hline Ny-BR-1 and GCDFP-15 & $2(1.7,0.4-6.1)$ & $2(1.7,0.4-6.1)$ \\
\hline Any markers (without BCA-225) & $97(84.3 ; 76.6-89.8)$ & $40(34.7 ; 26.6-43.8)$ \\
\hline
\end{tabular}

Table 3. Breast marker expressions in the tumors investigated 


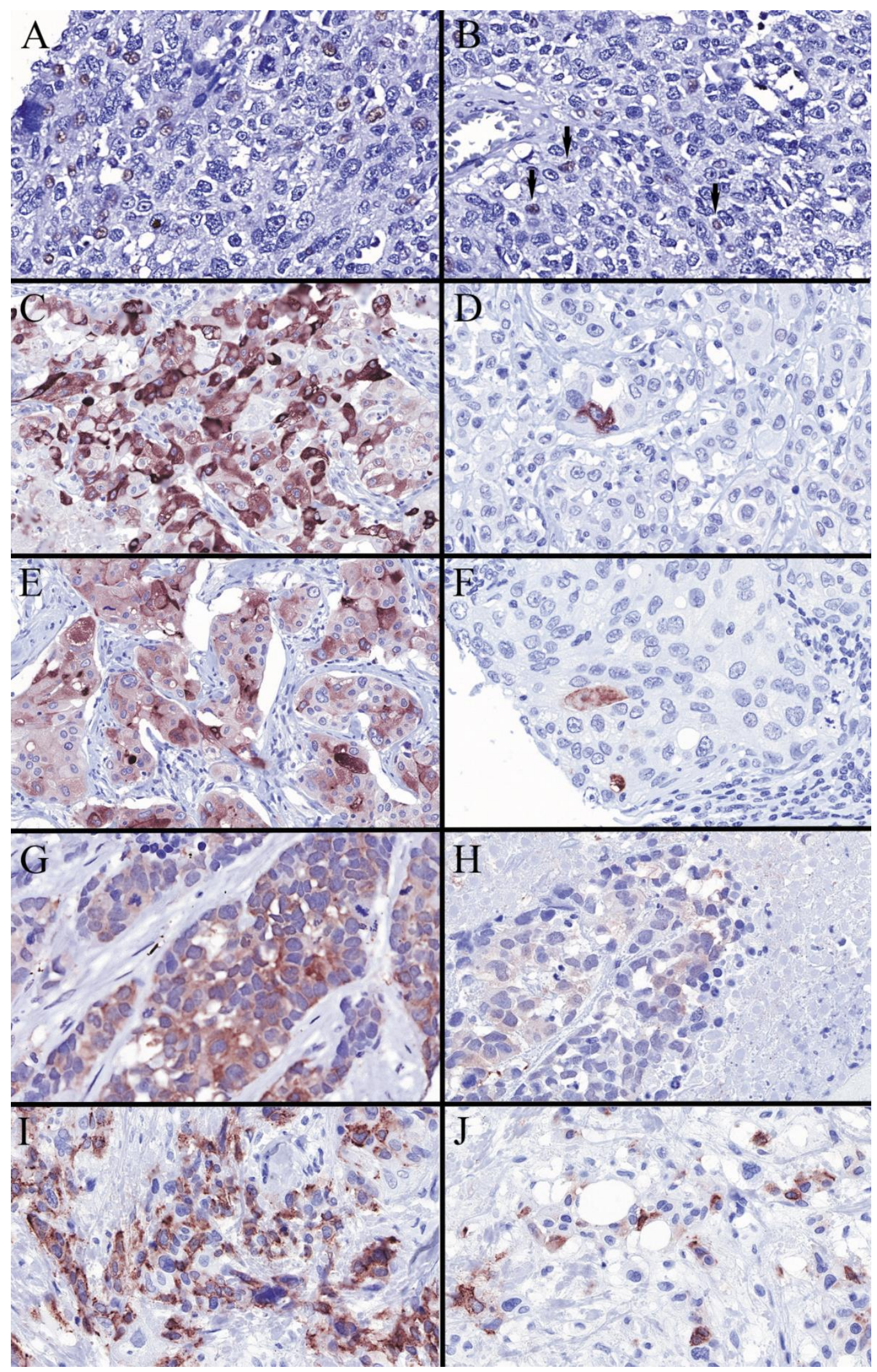

Figure 5. Examples of noticeable (at least 5\%) GATA-3, Mammaglobin-A, GCDFP-15, NY-BR-1 and BCA-225 staining on the left (A, C, E, G, I, respectively) as opposed to focal and weak staining with these markers (B, D, F, H, J, respectively) on the right. Arrows in B indicate the few weakly stained nuclei. 


\begin{tabular}{|c|c|c|c|c|c|c|c|c|}
\hline Any staining & GATA3+ & GATA3- & MG+ & MG- & GCDFP-15+ & GCDFP-15- & NY-BR-1+ & NY-BR-1- \\
\hline \multicolumn{9}{|c|}{\begin{tabular}{l|l|l} 
GATA3+ & & \\
\end{tabular}} \\
\hline GATA3- & na & & & & & & & \\
\hline MG+ & 21 & 8 & & & & & & \\
\hline MG- & 61 & 25 & na & & & & & \\
\hline GCDFP-15+ & 16 & 6 & 11 & 11 & & & & \\
\hline GCDFP-15- & 66 & 27 & 18 & 75 & na & & & \\
\hline NY-BR-1+ & 2 & 3 & 0 & 5 & 1 & 4 & & \\
\hline NY-BR-1- & 80 & 30 & 29 & 81 & 21 & 89 & na & \\
\hline BCA225+ & 57 & 16 & 23 & 50 & 16 & 57 & 3 & 70 \\
\hline BCA225- & 25 & 17 & 6 & 36 & 6 & 36 & 2 & 40 \\
\hline $5 \%$ cut-off & GATA3+ & GATA3- & MG+ & MG- & GCDFP-15+ & GCDFP-15- & NY-BR-1+ & NY-BR-1- \\
\hline \multicolumn{9}{|l|}{ GATA3+ } \\
\hline GATA3- & na & & & & & & & \\
\hline MG+ & 2 & 10 & & & & & & \\
\hline MG- & 21 & 82 & na & & & & & \\
\hline GCDFP-15+ & 2 & 6 & 2 & 6 & & & & \\
\hline GCDFP-15- & 21 & 86 & 10 & 97 & na & & & \\
\hline NY-BR-1+ & 0 & 1 & 0 & 1 & 0 & 1 & & \\
\hline NY-BR-1- & 23 & 91 & 12 & 102 & 8 & 106 & na & \\
\hline BCA225+ & 8 & 31 & 4 & 35 & 4 & 35 & 0 & 39 \\
\hline BCA225- & 15 & 61 & 8 & 68 & 4 & 72 & 1 & 75 \\
\hline
\end{tabular}

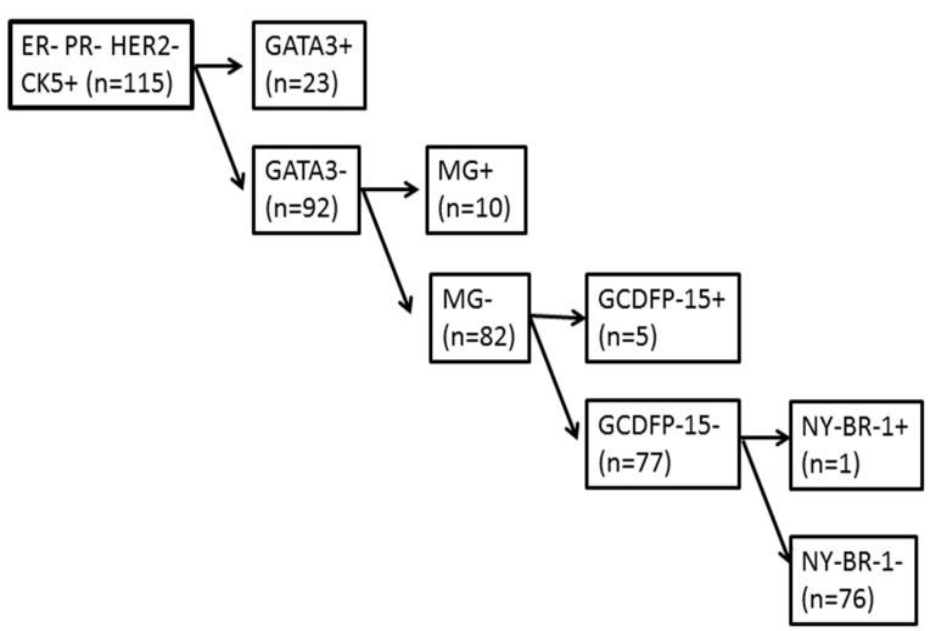

Table 4. Mutual breast marker expressions in the tumors investigated

Figure 6. Hierarchical labeling of the tumors with 4 "breast specific" markers. 
Taking any staining into account, GATA3 and BCA-225 labeling was seen in the majority of the cases, followed by MG and GCDFP-15, whereas NY-BR-1 immunoreactivity was seen in only a few tumor samples. Using the 5\% cut-off, there was a marked drop in the proportion of cases showing GATA3 positivity, but reductions were seen with all markers. Only one third of the cases showed notable (at least 5\%) staining with any of the 4 markers considered to be more specific for a breast origin if a few caveats are kept in mind. Using the frequency of labeling in this series, Figure 6 shows the hierarchical help that each of the markers can give in the assessment of a mammary origin of CK5 positive TNBCs. It is clear from the figure as from overall data that NY-BR-1 is not of great help in this context. BCA225 which is breast specific only in its name and data-sheet, stained only 25/76 of the tumors negative for all 4 other markers.

\subsection{EVALUATION OF REGRESSION PATTERNS IN BREAST CANCER AFTER PST}

In this series, 106 cases were included: 56 and 50 patients from the University of Szeged and the Bács-Kiskun County Teaching Hospital, respectively. The basic clinical characteristics of these cases, namely age, type of surgery, histological type of tumor, ypT, ypN categories, pretreatment grade and therapy received are summarized in Supplementary table 2. Seven patients having stage IV disease defined by distant metastasis received palliative chemotherapy before surgery.

The morphological parameters evaluated are displayed in Table 5. In all IHC approached molecular subtypes defined by the St. Gallen Consensus Conference in 2013, diminution was the most frequent size alteration after PST. The Spearman rank correlation revealed that the concordance between post-treatment pathological size and radiological size (defined by US examination) was high $(\mathrm{p}=0.002)$.

Regarding the homogeneity of regression, the luminal A, HER-2 and TNBCs showed more homogeneity, whereas luminal B cases demonstrated more inhomogeneity. Unfortunately, statistical analysis could not been applied due to the low case number in the groups. Lack of any regression, uniform degree of regression and pCR were observed in $7.5 \%, 18.8 \%$ and $28.3 \%$ of all cases, respectively. The vast majority of inhomogeneous regression was minor inhomogeneity (36.7\% of all cases). The scatter pattern was identified in only 7 cases $(6.6 \%)$, while CS was the rarest $(n=2 ; 1.8 \%)$. The regression inhomogeneity is demonstrated in Table 6 displaying the distribution of complete regression and the lack of any regression patterns at the different magnifications evaluated. In the lymph node specimens, 
homogeneity was more frequent (homogeneity: $45.3 \%$ versus inhomogeneity: $23.5 \%$ of all cases). In cases having neither metastasis nor regression in the lymph nodes, homogeneity of regression or its lack could not be evaluated $(31.2 \%)$.

Cellularity changes reflected decrease in most cases (two thirds of all patients) but an increase was recorded in a significant minority (15.1\%). The correlation between changes in cellularity and the alterations of post-treatment pathological and radiological tumor sizes compared to the pretreatment US size were significant ( $\mathrm{p}=0.04$ and $\mathrm{p}=0.03$, respectively). After exclusion of cases showing pCR following PST (where grade alteration was not interpretable) the grade of tumors was unchanged in $72.4 \%$. Upgrading and downgrading were detected in 10 and 10 cases (13.8\% and 13.8\%), respectively. The latter was not seen among patients having TNBC. 


\begin{tabular}{|c|c|c|c|c|}
\hline & Luminal A-like & Luminal B-like & HER-2 & TNBC \\
\hline \multirow[t]{2}{*}{ Morphological variable } & $\mathrm{n}(\%)$ & $\mathrm{n}(\%)$ & $\mathrm{n}(\%)$ & $\mathrm{n}(\%)$ \\
\hline & $20(100)$ & $29(100)$ & $26(100)$ & $31(100)$ \\
\hline \multicolumn{5}{|l|}{ Radiological size alteration } \\
\hline shrinkage & $15(75)$ & $26(89)$ & $24(92.4)$ & $25(80.6)$ \\
\hline growth & $2(10)$ & $0(0)$ & $2(7.6)$ & $4(12.9)$ \\
\hline unchanged & $2(10)$ & $3(11)$ & $0(0)$ & $2(6.5)$ \\
\hline no data & $1(5)$ & $0(0)$ & $0(0)$ & $0(0)$ \\
\hline \multicolumn{5}{|l|}{ Regression pattern in the resection specimen } \\
\hline pCR & $0(0)$ & $6(20.7)$ & $12(46.2)$ & $12(38.7)$ \\
\hline uniform degree of regression & $11(55)$ & $3(10.3)$ & $2(7.6)$ & $4(12.9)$ \\
\hline lack of any regression & $3(15)$ & $1(3.4)$ & $1(3.8)$ & $3(9.6)$ \\
\hline Inhomogeneous & $6(30)$ & $19(65.6)$ & $11(42.3)$ & $12(38.7)$ \\
\hline minor inhomogeneity & $5(25)$ & $17(58.8)$ & $9(34.7)$ & $8(25.9)$ \\
\hline "scatter pattern" & $1(5)$ & $2(6.8)$ & $1(3.8)$ & $3(9.6)$ \\
\hline $\begin{array}{lr} & \text { concentric shrinkage } \\
\end{array}$ & $0(0)$ & $0(0)$ & $1(3.8)$ & $1(3.2)$ \\
\hline \multicolumn{5}{|l|}{ Regression pattern in the lymph node specimen } \\
\hline inhomogeneous & $7(35)$ & $10(34.5)$ & $4(15.4)$ & $4(12.9)$ \\
\hline not applicable & $4(20)$ & $7(24.2)$ & $9(34.6)$ & $13(41.9)$ \\
\hline \multicolumn{5}{|l|}{ Change in cellularity } \\
\hline decreased & $15(75)$ & $23(79.5)$ & $21(80.8)$ & $22(70.9)$ \\
\hline increased & $2(10)$ & $3(10.3)$ & $4(15.4)$ & $7(22.6)$ \\
\hline unchanged & $3(15)$ & $1(3.4)$ & $1(3.8)$ & $2(6.5)$ \\
\hline no data & $0(0)$ & $2(6.8)$ & $0(0)$ & $0(0)$ \\
\hline \multicolumn{5}{|l|}{ Change in grade } \\
\hline decreased & $4(20)$ & $3(10.3)$ & $3(11.5)$ & $0(0)$ \\
\hline increased & $2(10)$ & $5(17.3)$ & $0(0)$ & $3(9.6)$ \\
\hline unchanged & $14(70)$ & $12(41.4)$ & $11(42.3)$ & $15(48.3)$ \\
\hline no data & $0(0)$ & $9(31.0)$ & $12(46.2)$ & $13(41.9)$ \\
\hline \multicolumn{5}{|l|}{ Presence of "monster" cells } \\
\hline present & $5(25)$ & $6(20.6)$ & $3(11.5)$ & $5(16.1)$ \\
\hline absent & $15(75)$ & $23(79.4)$ & $23(88.4)$ & $26(83.9)$ \\
\hline
\end{tabular}

Table 5. Morphological features of cases evaluated, displayed according to the molecular subtypes of breast cancer (HER-2: human epidermal growth factor receptor-2; TNBC: triple negative breast cancer, pCR: pathological complete regression) 


\begin{tabular}{|l|c|c|c|c|c|c|c|c|c|}
\hline \multirow{2}{*}{$\begin{array}{l}\text { Patterns of } \\
\text { inhomogeneity }\end{array}$} & & \multicolumn{3}{|c|}{ complete regression pattern at magnification of/on } & \multicolumn{3}{|c|}{ lack of any regression pattern at magnification of/on } \\
\cline { 2 - 10 } & $\mathbf{n}$ & whole slide & $\mathbf{4 x}$ & $\mathbf{1 0 x}$ & $\mathbf{a b s e n t}$ & whole slide & $\mathbf{4 x}$ & $\mathbf{1 0 x}$ & absent \\
\hline $\begin{array}{l}\text { minor } \\
\text { inhomogeneity }\end{array}$ & $\mathbf{3 9}$ & 0 & $19(48.7)$ & $14(35.8)$ & $6(15.5)$ & $3(7.8)$ & $15(35.5)$ & $9(23)$ & $12(30.7)$ \\
\hline scatter pattern & $\mathbf{7}$ & $7(100)$ & 0 & 0 & 0 & 0 & $2(28.5)$ & $3(43)$ & $2(28.5)$ \\
\hline $\begin{array}{l}\text { concentric } \\
\text { shrinkage }\end{array}$ & $\mathbf{2}$ & 0 & $2(100)$ & 0 & 0 & 0 & 0 & $1(50)$ & $1(50)$ \\
\hline
\end{tabular}

Table 6. Morphological characteristics of regression patterns

Note: When a pattern was present on the whole slide, it was also present in a medium power (10x) and low power (4x) field, too; but the numbers in the table reflect only the largest of the three areas assessed. 
"Monster" cells were seen in $17.9 \%(\mathrm{n}=19)$ of all cases. They were present in pre- and posttreatment grade 2 and 3 tumors exclusively. Their possible influence on grade alteration and association with PST are demonstrated in Table 7. Among these findings, the following are underlined: in 5 cases, upgrading (grade 2 to posttreatment y-grade 3) was detected in presence of "monster" cells, and the monster cells were present only (all but one case) in patients who received PST including a taxane.

No correlation was found between the molecular subtypes and treatment related alteration in (pathological) size, cellularity, grade, the homogeneity of regression in lymph node specimens and presence of "monster" cells.

\begin{tabular}{|r|c|c|}
\hline & \multicolumn{2}{|c|}{ monster cells } \\
\hline Alteration of grade & present & absent \\
\hline increased & 5 & 5 \\
\hline decreased & 1 & 9 \\
\hline unchanged & 11 & 41 \\
\hline no data & 2 & 32 \\
\hline anthracycline +/- targeted therapy & 1 & 8 \\
\hline taxane +/- platinum derivatives & 4 & 23 \\
\hline anthracycline + taxane & 15 & 55 \\
\hline
\end{tabular}

Table 7. Relation between alterations of grade, therapy received and "monster" cells, respectively.

\subsection{EVALUATION OF REGRESSION HETEROGENEITY IN AXILLARY LYMPH NODES AFTER PST}

The mean $( \pm$ S.D.) age of the patients was $50.2( \pm 11.0)$ years. The neoadjuvant treatment involved hormonal therapy with aromatase inhibitors in 10 cases, whereas the remaining patients received chemotherapies. There were 110 ER positive tumors (including 25 HER2 positive cases), and of the 32 ER negative tumors, 12 were HER2 positive by immunohistochemistry or in situ hybridization. Complete primary tumor regression with or without residual in situ carcinoma was seen in 24 cases, and no signs of regression were reported in 16 primary cancers. No nodal regression at all was evidenced in 19 node-positive cases, whereas the number of cases having at least 
one metastatic lymph node without evidence of regression (NR4) was 55. A median of 2 SLNs (range: 1-8) and 14 non-SLNs (range: 2-42) were removed from the patients. The metastasis and regression status of the analyzed cases are summarized in Table 8.

The practice of SLN biopsy in locally advanced breast cancer patients receiving neoadjuvant systemic treatment is still somewhat controversial. Often the SLN biopsy was performed before primary systemic therapy or was not performed because of previously evidenced metastatic lymph nodes. The required cases were relatively rare in our archives, and the present study should be regarded as an exploration of the theory of a potential selective regression (or non-regression) in SLNs. Categories B, C0, F, H, I, J and N represented 87/142 cases including 40 nodepositive cases without evidence of regression in the lymph nodes (Table 8), and were indifferent towards the tested hypothesis. Of the 89 cases with signs of nodal regression, 22 cases were in categories A, C2, E and G, where the regression was of greater degree in non-SLNs (22/89 cases, 25\%). Only 18/89 cases (20\%) fell into category $\mathrm{C} 1, \mathrm{D}$ or $\mathrm{K}$, and were in support of a selective and more pronounced regression in the SLNs. 


\begin{tabular}{|c|c|c|c|c|c|c|}
\hline SN metastasis & SN regression & NSN metastasis & $\mathrm{NSN}$ regression & Category & Support the theory? & No. of cases \\
\hline \multirow{10}{*}{ Yes } & \multirow{6}{*}{ Yes } & \multirow{2}{*}{ No } & Yes & A & No & 9 \\
\hline & & & No & B & Indifferent & 15 \\
\hline & & \multirow{4}{*}{ Yes } & Yes $(=\mathrm{SN})$ & $\mathrm{CO}$ & No & 11 \\
\hline & & & Yes $(<\mathrm{SN})$ & $\mathrm{C} 1$ & Yes & 5 \\
\hline & & & Yes $(>\mathrm{SN})$ & $\mathrm{C} 2$ & No & 8 \\
\hline & & & No & $\mathrm{D}$ & Yes & 6 \\
\hline & \multirow{4}{*}{ No } & \multirow{2}{*}{ No } & Yes & $\mathrm{E}$ & No & 3 \\
\hline & & & No & $\mathrm{F}$ & Indifferent & 24 \\
\hline & & \multirow{2}{*}{ Yes } & Yes & $\mathrm{G}$ & No & 5 \\
\hline & & & No & $\mathrm{H}$ & Indifferent & 18 \\
\hline \multirow{8}{*}{ No } & \multirow{4}{*}{ Yes } & \multirow{2}{*}{ No } & Yes & $\bar{I}$ & Indifferent & 11 \\
\hline & & & No & $\mathrm{J}$ & Indifferent & 2 \\
\hline & & \multirow{2}{*}{ Yes } & Yes & K & Yes & 1 \\
\hline & & & No & $\mathrm{L}$ & Yes & 0 \\
\hline & \multirow{4}{*}{ No } & \multirow{2}{*}{ No } & Yes & $\mathrm{M}$ & False negative SLN & 7 \\
\hline & & & No & $\mathrm{N}$ & Indifferent & 9 \\
\hline & & \multirow{2}{*}{ Yes } & Yes & $\mathrm{O}$ & False negative SLN & 6 \\
\hline & & & No & $\mathrm{P}$ & False negative SLN & 2 \\
\hline
\end{tabular}

Table 8. Categorization of the results on the basis of possible variations in the distribution of metastases and regression and their relation to support the theory of a possible selective regression pattern in SLNs 


\subsection{ANALYSIS OF LUMEN FORMING UNITS IN CASES OF DIFFUSE DCIS WITH COMEDO-LIKE NECROSIS AND CASTING TYPE CALCIFICATION}

Twenty seven slides from 21 female patients were investigated in this retrospective study (median 1 slide/case). The mean age of the patients was 63.7 (range 46-86). The basic clinicopathological parameters are displayed in Supplementary table 3. Two thirds of the patients had high grade DCIS with invasive carcinoma of no special type. The mean \pm S.D. invasive tumor size and tumor extension (including DCIS as well) were $13.9 \pm 17.7 \mathrm{~mm}$ [range: 0-65 $\mathrm{mm}$ ] and $44.4 \pm 30.7 \mathrm{~mm}$ [range: 12-65 $\mathrm{mm}$ ], respectively. The invasive component showed almost exclusively high nuclear grade. The in situ component was of high grade in all but one case. Estrogen receptor and progesterone receptor positivity were observed in 13 cases and 11 cases, respectively. Intense, concentric membranous positivity of HER-2 was seen in 13 cases (61.9\%). Centrally calcified comedo type necrosis was present in all cases, and casting (linear branching) type calcification on the mammogram was documented in 18 cases; two cases had mammography elsewhere and no data on the type of calcifications were available, and two cases had granular rather than casting type calcification described in the radiological report.

Altogether 1220 structures were classified as ducts or acini with different levels of certitude, as described in the methods. The majority (nearly two thirds) were unclassifiable, and between 7.4 and 13.6 per cent belonged to one of the 4 remaining categories each. The relation of these classified structures to peristructural elastic fibers is shown in table 9. The concentric presence of elastic fibers is more frequent around structures identified as ducts or likely ducts, but was also seen around a minority of unclassifiable structures. At the opposite end of the spectrum, acini lack elastic fibers around, similarly to likely acini. Most unclassifiable structures are also completely or partially (dominant absence pattern) devoid of peristructural elastic fibers (Fig 7). 


\begin{tabular}{|c|c|c|c|c|c|c|c|c|c|c|}
\hline \multirow{3}{*}{ Duct vs. Acinus } & \multicolumn{8}{|c|}{ Elastic fibers } & \multirow{3}{*}{ All (n) } & \multirow{3}{*}{ All $(\%)$} \\
\hline & \multicolumn{2}{|c|}{ Absence } & \multicolumn{2}{|c|}{$\begin{array}{c}\text { Dominant } \\
\text { absence }\end{array}$} & \multicolumn{2}{|c|}{$\begin{array}{c}\text { Dominant } \\
\text { presence }\end{array}$} & \multicolumn{2}{|c|}{$\begin{array}{c}\text { Concentric } \\
\text { presence }\end{array}$} & & \\
\hline & $\mathbf{n}$ & $\%$ & $\mathbf{n}$ & $\%$ & $\mathbf{n}$ & $\%$ & $\mathbf{n}$ & $\%$ & & \\
\hline Duct & 5 & 0.4 & 9 & 0.7 & 24 & 1.9 & 53 & 4.4 & 91 & 7.4 \\
\hline Likely duct & 21 & 1.3 & 34 & 2.9 & 25 & 2 & 33 & 2.7 & 113 & 8.9 \\
\hline Unclassifiable & 559 & 45.9 & 142 & 11.7 & 36 & 3.1 & 25 & 2 & 762 & 62.7 \\
\hline Likely acinus & 88 & 7.3 & 1 & 0.07 & 1 & 0.07 & 0 & 0 & 90 & 7.44 \\
\hline Acinus & 162 & 13,4 & 2 & 0.16 & 0 & 0 & 0 & 0 & 164 & 13.56 \\
\hline All & 835 & 68.3 & 188 & 15.53 & 86 & 7.07 & 111 & 9.1 & 1220 & 100 \\
\hline
\end{tabular}

Table 9. The proportions of elastic fibers around the evaluated structures

Ducts $(n=33)$ and acini $(n=150)$ of control breast slides were also analyzed for the presence of elastic coating around these normal structures. The Mann-Whitney test revealed significant difference between ducts and acini: a concentric elastic fiber layer surrounds almost all normal ducts, but the acini do not have such an elastic coating $(\mathrm{p}<0.001)$.

Neoductgenesis was identified in six $(25.5 \%)$ cases by using the neoductgenesis score suggested by Zhou and coworkers. After the application of this scoring system to all numbered structures, we found that in neoductgenesis positive tumors, $27.3 \%$ of the numbered units were suggested as neoducts and there was hardly any potential neoducts $(0.75 \%)$ in neoductgenesis negative tumors.

We examined the means of the scores of numbered individual structures per case, as well. In neoductgenesis positive tumors $(n=6)$, the average of the neoductgenesis related scores was higher (mean \pm S.D.: $3.87 \pm 0.35$, range: 3.49-4.39) than in neoductgenesis negative cases (mean \pm S.D.: 1.97 \pm 1.11 , range: 0-3.1). 


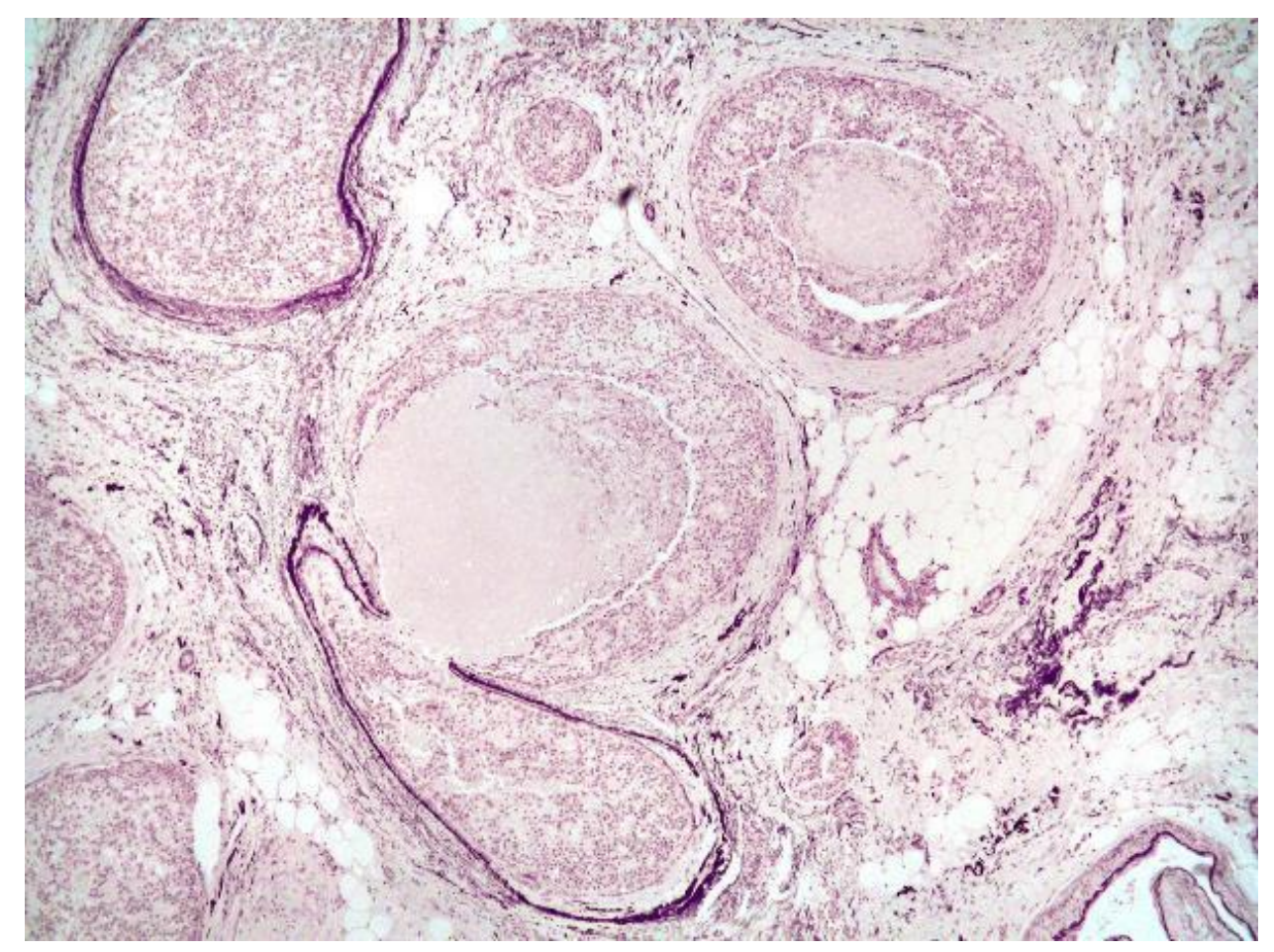

Figure 7: Elastic fibers around ducts involved by DCIS, and their lack around similar structures, that could represent neoducts, but do not reach an individual score for the qualification as neoduct in a neoductgenesis negative case on the basis of the overall score (Orcein, 4x). Note the branching of the elastic fiber-negative structure from the elastic fiberpositive duct.

Two thirds of these neoducts identified by the per structure scoring system are irregular and uncertainly classifiable structures (table 10) and almost $80 \%$ of them are not or dominantly not surrounded by elastic fibers. The chi-square test revealed a significant difference between the normal structures and the individual score based neoducts: the latter generally do not have an elastic layer around $(\mathrm{p}<0.001)$.

\begin{tabular}{|c|c|c|c|c|c|c|c|c|c|c|}
\hline \multirow{3}{*}{ Neoduct } & \multicolumn{8}{|c|}{ Elastic fibers } & \multirow{3}{*}{ All (n) } & \multirow{3}{*}{ All (\%) } \\
\hline & \multicolumn{2}{|c|}{ Negative } & \multicolumn{2}{|c|}{$\begin{array}{c}\text { Rather } \\
\text { negative }\end{array}$} & \multicolumn{2}{|c|}{$\begin{array}{l}\text { Rather } \\
\text { positive }\end{array}$} & \multicolumn{2}{|c|}{$\begin{array}{c}\text { Concentric } \\
\text { positivity }\end{array}$} & & \\
\hline & $\mathbf{n}$ & $\%$ & $\mathbf{n}$ & $\%$ & $\mathbf{n}$ & $\%$ & $\mathbf{n}$ & $\%$ & & \\
\hline Duct & 3 & 1.4 & 5 & 2.4 & 5 & 2.4 & 15 & 6.9 & 28 & 13.1 \\
\hline Likely duct & 5 & 2.4 & 13 & 6.2 & 9 & 4.2 & 5 & 2.4 & 32 & 15.2 \\
\hline Unclassified & 109 & 50 & 20 & 9.3 & 5 & 2.4 & 5 & 2.4 & 139 & 64.1 \\
\hline Likely acinus & 8 & 3.7 & 1 & 0.6 & 0 & 0 & 0 & 0 & 9 & 4.3 \\
\hline Acinus & 7 & 3.3 & 0 & 0 & 0 & 0 & 0 & 0 & 7 & 3.3 \\
\hline All & 132 & 60.8 & 39 & 18.5 & 19 & 9 & 28 & 11.7 & 218 & 100 \\
\hline
\end{tabular}

Table 10. The morphological characteristics of potential neoducts $(n=218)$ 
In neoductgenesis positive and negative tumors, the presence of elastic fibers was evaluated by scoring of each structure on orcein stained slides as described in the methods. Lower scores were found in the neoductgenesis positive tumors (mean \pm S.D.: $0.57 \pm 0.32$, range: $0.28-0.91$ ) than in neoductgenesis negative neoplasms (mean \pm S.D.: $0.89 \pm 0.54$, range: $0.1-2.1)$.

\section{DISCUSSION}

\subsection{IMMUNOHISTOCHEMICAL EVALUATION OF BASAL-LIKE TNBCS}

TNBCs are defined by their negativity for ER, PR and HER2. Despite this defining phenotypic character, they still represent a heterogeneous group of breast carcinomas [101]. Some subsets of TNBCs can be relatively well identified using IHC, for example androgen receptor and diffuse GCDFP-15 positivity can identify apocrine carcinomas [102], and it has been suggested that tumors expressing CK5 and/or EGFR are those that best match the molecular subtype of basal-like carcinomas [103]. Basal-like TNBCs are often circumscribed (a feature shared by many metastases), predominantly solid, without much lumen-forming tendency, and they often feature necrosis, squamous metaplasia, all rendering their identification as breast carcinoma more difficult. They are aggressive tumors with a tendency to give distant metastases on the short term. Metastases to the breast are rare, but metastases from TNBCs are relatively common. Identification of a tumor as primary TNBC or a metastasis from TNBC is relevant diagnostically, therapeutically, but can be important from tissue archival and tumor banking aspects too.

Proving the mammary origin of TNBCs may be problematic, as ER, one of the most commonly used, but not specific markers of breast origin is by definition absent in these tumors. In the present study we investigated the expression of 5 markers developed or used to support the mammary origin of cancers according to the descriptions in the data sheets, (namely GATA-3, MG, GCDFP-15, NY-BR-1 and BCA-225) by IHC in a series of TNBCs deemed to be of the basal-like type on the basis of their CK5 expression.

Using the 5\% cut-off, which is readily detectable, BCA-225 showed the highest expression rate with about one third of the cases staining, but this was well below the $98 \%$ staining rate found for breast cancers in general. Therefore, despite not being specific for 
breast cancer, the marker is also not sensitive enough. Owing to these features, it was dropped from further considerations.

Overall, more than $90 \%$ of breast cancers are GATA3 positive [51], whereas only about 50\%, 20 to 30\% and 46-70\% show positivity for MG [36], GCDFP-15 and NY-BR1 [50; 51], respectively. Most of the reported series suggest that positivity for both GATA3 and NY-BR-1 is more common in ER-positive tumors. GATA3 somatic mutations and microarray data have linked GATA3 to the estrogen signaling pathway, and therefore it is not surprising that the expression of this protein is lower in TNBCs, than in ER+ tumors or breast cancers in general, in keeping with previous results (Supplementary table 4).

Data on the staining frequency of GATA3, MG, GCDFP-15 and NY-BR-1 in TNBC are limited. Studies reporting on the expression of these markers on a relatively large number of primary or secondary TNBCs are summarized in Supplementary table 4. On the basis of these data, the sensitivity of GATA-3, Mammaglobin-A, GCDFP-15 and NY-BR-1 to suggest a mammary origin are $43.5 \%$ (95\%CI $0.396-0.476), 16.4 \%$ (95\%CI: $0.136-0.196), 15.1 \%$ (95\%CI: 0.127-0.179) and 5.4\% (95\%CI: 0.027-0.103), respectively.

Despite the fact that GATA-3 expression has been linked with ER expression, this was the marker to show the highest frequency of staining in CK5 expressing TNBCs. When 5\% and more staining was chosen as a cut-off for positivity, the frequency of each marker decreased (Tables 3 and 4). Lower percentages of staining must be interpreted with caution as the specificity of such a low labeling is uncertain.

When our results are compared with those of others (Supplementary table 4), the positivity rates for GATA-3 and GCDFP-15 are lower in our TMA based series. A potential weakness of the present study could be the use of TMAs, because MG and GCDFP-15 often stain breast carcinomas in a patchy pattern [38], and the sensitivity of detecting these markers can be lower in TMAs than on whole slide sections. This could be one possible cause of the discrepancy between our results and those of others listed in Supplementary table 4, although two 2-mm-diameter cores are a relatively good representation of a tumor in TMA based studies. Another issue behind the difference in results might stem from the fact, that we studied a distinct subset of TNBCs.

TNBCs are heterogeneous [101], and some of them, belonging to the luminal androgen receptor positive group, are characterized by forkhead-box A1 (FOXA1) protein 
overexpression [104]. FOXA1 and GATA-3 are both involved in the downstream of the ER pathway. Diffuse GCDPF-15 is also a marker of apocrine differentiation in IHC studies [102; 105]. Such tumors were excluded by selecting basal-like matching carcinomas on the basis of their CK5 expression. Such differences in the subgroups analyzed may also contribute to the lower rates of positivity of GATA-3 and GCDFP-15 in this series; it is believed that this is the main reason for the discrepancy.

Possible differences may also be attributable to the use of different antibodies/clones. But this is unlikely to be a major source of differences as 4 studies used the same antibody clones as we used for GATA3 $[12 ; 13 ; 106 ; 107]$. The fact that we studied primary tumors rather than metastases is also unlikely to explain lower expression rates in the present series. The evaluation of primary tumors may be a limitation of the present study due to possible changes of phenotype between a primary tumor and its metastases, but if primary basal-like TNBCs show such a low expression of the studied markers, expecting much wider immunoreaction in metastases would seem unrealistic.

To our knowledge, this is the largest series of TNBC analyzed for the expression of 4 markers of mammary origin, moreover the series includes exclusively TNBC of a distinct subtype, namely tumors expressing CK5 and therefore most likely to coincide with basal-like breast carcinomas [103]. If we consider the documented lack of specificity of BCA-225 [53], the remaining 4 breast markers fail to show any staining in about 15\% of CK5 expressing TNBCs. A more detectable (at least 5\%) expression of any of the 4 markers was seen in around one third of the cases, leaving the remaining two thirds unidentified as of mammary origin. Of the 4 markers, NY-BR-1 is rarely expressed in the tumor subset studied, and therefore its use adds practically nothing to the use of the other three.

The expression of GATA3, MG, GCDFP-15 and NY-BR-1 is lower in TNBCs than in breast carcinomas in general. Although these markers may be positive in different other tumors, by using them, a subset of basal-like TNBC-s can be identified as of mammary origin. Though the positive staining supports a breast origin, negativity for all markers does not exclude this. Therefore we suggest using GATA-3, MG and GCDFP-15 as an IHC panel to establish breast origin when ER and PR are negative. Obviously, at the primary site, histological features such as the presence of in situ carcinoma of similar grade may also suggest the primary nature of the tumor, but this help is missing in the metastatic setting. One 
should be prepared to find a relatively high number of basal-like TNBCs to be negative for all the studied breast markers.

\subsection{EVALUATION OF REGRESSION PATTERNS IN BREAST CANCER AFTER PST}

The concepts of PST were developed in the last years and offer an alternative option for patients having primary breast cancer. The aims of PST are combination of systemic treatment and surgical treatment in order to eliminate all tumor cells, downstaging breast cancers to make them operable by breast conserving options, and enabling the assessment of regression by pathological means [108-110]. In PST studies, the pathological diagnosis is the most important parameter for the generation of study endpoints [111]. The histopathological changes after PST are complex, therefore careful systematic analysis of the specimen is required for accurate diagnosis and treatment. The standardization of specimen handling and histological interpretation is essential for approaching pCR as an indicator in PST studies, or for measuring residual disease [63].

Although one of the most cardinal features of residual disease is the tumor size, it is often difficult to determine after PST. Besides the hardships of systematic sampling of the tumor bed, residual tumor may be present as multiple, small scattered foci. In the latter case, the size of the largest invasive focus determines the ypT category according to the $8^{\text {th }}$ edition of the AJCC staging system [6], while the extent defined by the largest dimension inclusive of all independent invasive foci may be better for comparison with radiologic size [65]. Our findings have demonstrated, that pathological tumor size correlates with radiological (US) size, and the alteration of pathological size is in keeping with radiological findings $[112 ; 113]$.

Primary chemotherapy selectively eliminates the proliferating cells, therefore the mitotic activity and the cellularity may decrease. Though the change in cellularity is one of the most representative features of PST [114], it is not recorded routinely in the histopathological reports because it is not easy to assess, lacks standardization and is an important parameter in only some tumor-response systems [68; 115] while it is not one in others [116-118]. Cellularity is utilized in two regression grading systems: in the Miller-Payne and in the Residual Cancer Burden system (RCB). Regarding the five-tiered Miller-Payne system, the pre- and post PST cellularity are compared, and the presence of invasive carcinoma is considered [68]. The four-tiered RCB is based on the size of the tumor bed in 
two dimensions, tumor cellularity in the post-treatment specimen, the proportion of DCIS in residual cancer, the number of lymph nodes with residual metastasis and the size of the largest lymph node metastasis [115]. In the present series, biopsies taken before PST and resection specimens were evaluated for cellularity changes. In the vast majority of the cases, cellularity has declined and a significant correlation was detected between alterations of cellularity and (pathological) size.

Our findings suggest that homogeneity and inhomogeneity of regression are not associated with any molecular subtypes, and both are present approximately in half of the cases. The majority of inhomogeneous regression represented minor inhomogeneity seen in differences between one and the other medium or low power field, while the scatter pattern and CS were exceptionally rare. Although, the most remarkable pattern is the scatter pattern regarding the problems of tumor bed sampling, where complete slides may be present without residual cancer, minor heterogeneity may also cause diagnostic controversy if only core biopsy is taken after PST.

Several ongoing or completed studies on PST feature post-PST biopsies as parts of their design [119-123]. By taking interim or final biopsies, pathological response and the effects of treatment can be characterized. Tumor and response heterogeneity, especially the scatter pattern of regression may have an impact on these studies. Limited sampling by biopsies may be the source of misinterpretations, if the biopsy is taken from the part of tumor bed showing complete response, or another part lacking any response. To avoid these diagnostic pitfalls, generous sampling by multiple biopsies is recommended for cases showing the extremes on the scale of regression, if the assessment of the complete tumor bed is not feasible.

Histological grade of breast cancer is one of the most established traditional prognostic factors. Honkoop and coworkers have found significant decline in mitotic activity following PST [124], while Sharkey et al have identified significant increase of nuclear pleomorphism [125]. While the decline of mitotic count can lead to "downgrading", more severe nuclear atypia could result in "upgrading". The result of these contradirectional changes may alter the posttreatment histological grade. We have demonstrated that up- and downgrading are rare, especially because the majority of PST case belong to grade 3. In half of the cases with upgrading, monster cells were present. 
The monster cells (Figure 2H-I) are giant tumor cells often having hyperchromatic macronuclei or multilobated or multiple nuclei and they are associated with effects of PST [125]. The presence of these cells was associated with taxane treatment. The principal effect of taxane is the disruption of microtubule function, including the blockage of the mitotic spindle. Microtubules are essential to cell division, and taxanes stabilize GDP-bound tubulin in the microtubule, thereby inhibiting the process of cell division as depolymerization is prevented. The tumor cells are not able to divide after the duplication of their chromatin content, and the result may be the formation of macronucleated "monster" cells. Our findings suggest that the presence of these monster cells may increase nuclear atypia and therefore it may lead to upgrading following PST. Due to polyploidization, such cells are also expected to show an increased copy number of many genes, including HER2, leading to a post-treatment positive status of questionable therapeutic significance in these cells [126].

Limitations of the present study could be the low number of cases and the exclusion of patients receiving PHT. Fukada and coworkers have reported that CS is significantly more frequent in luminal breast cancers following PHT, and these patients had significantly better outcome than patients having other patterns [127]. In contrast, there was no significant correlation between regression patterns and molecular subtypes in the present work. This discrepancy may be explained by the exclusion of cases with PHT.

To our knowledge, this is the first study describing the distribution of regression heterogeneity according to molecular subtypes. Our findings suggest that regression may be inhomogeneous in half of the cases, and it does not seem to be related to any molecular subtype, therefore the evaluation of the whole tumor bed is recommended for the best assessment of regression. The "monster" cells are related to PST including taxane derivate, and may cause upgrading in tumors with non-high grade nuclei at the start of PST.

\subsection{REGRESSION HETEROGENEITY OF AXILLARY LYMPH NODES}

There are some reservations regarding the possible conclusions of the study. The methods of SLN biopsy were obviously not uniform, but were the ones applied and relied on in clinical practice at the given institution. The nature of the therapeutic agents used for primary systemic treatment could not be taken into account, as there was a wide variation in the protocols and drugs used, and the low case numbers would not have made any treatmentspecific analysis possible. Altogether the case numbers are relatively small, however, the distribution of the cases did not point in favor or against a selective regression (or non- 
regression) in SLNs. Finally, fibrotic foci in the lymph nodes were interpreted as signs of regression, but these signs are not specific, and other processes may lead to the same morphological features. However, in the setting of neoadjuvant therapy, this latter is the most likely cause for these morphological changes, and therefore these were uniformly interpreted as signs of regression.

The evidence gathered from the limited number of cases available suggests that despite the attractiveness of a preferential regression (or non-regression) in tumor draining lymph nodes (SLNs which seem to be immunosuppressed and at the same time are the sites of TRL), there is no obvious difference in the degree of regressive histological changes shown by SLNs and NSLNs. Therefore, this phenomenon may not be a major contributor to the somewhat higher false negative rate of SLN biopsy after neoadjuvant treatment [128].

\subsection{DIFFUSE DCIS WITH COMEDO-LIKE NECROSIS AND AMORPHOUS CALCIFICATION}

Our study of a large number of breast microanatomic structures suggests that most of the densely packed structures involved by morphological DCIS with comedo necrosis cannot be classified on the basis of the HE look as ducts or acini. The study of the control cases reinforced the known microanatomy of ducts and lobules, of which only the previous have an elastic coating. The study also demonstrated that DCIS involved structures that could be classified as ducts or acini with some certainty displayed the elastic coating expected on the basis of the normal anatomic structures. On the other hand, most structures that could not be reliably classified as ducts or acini, in parallel with most structures classified as representing neoducts on the basis of the proposed scoring system [96] adapted to the individual structures were devoid of an elastic coating. Although this could be used as a support to the acinar origin of these structures, it is more realistic to suggest that together with previously described stromal periductal tenascin-C accumulation [83; 84], this could be another difference between preexisting and newly formed ducts. It is not known whether the proposedly new ducts are devoid of periductal elastic fibers from the beginning, or these fibers are lost as a consequence of periductal inflammation and/or fibrosis.

Myoepithelial cells have been reported to have an altered phenotype in some DCIS cases, characterized by the loss of one or more myoepithelial markers labeling the myoepithelium around normal anatomic mammary structures. The phenomenon occurs more frequently in high-grade DCIS. None of the present cases were of low grade, and all but one 
case were of high grade. Although we did not study the expression of myoepithelial markers, we detected another abnormality of high grade DCIS cases with comedo necrosis, namely the lack of elastic fibers around the ducts. This was not only present in cases which displayed a neoductgenesis score above 4 , but also in cases with lower scores.

Neoductgenesis is a concept to explain the morphology of certain breast cancers that show neoplastic cells in densely packed anatomic structures seemingly corresponding to either normal ducts or acini on the basis of the presence of a basement membrane and a myoepithelial layer at the outer surface, but not corresponding to any of these preexisting structures when looking at the lack of the tree-like distribution of normal anatomic structures described in the introduction. The theory suggests that some breast carcinomas are characterized by the outgrowth of new branches, i.e. new ducts, neoducts from the ductal tree, representing a pushing type infiltration. Densely packed, tumor involved, myoepithelium coated structures could theoretically represent engulfed preexisting acini (and ducts), but when one looks at the phenomenon of lobular cancerisation, where this neoplastic inflation happens, or at ductectasia or cystic changes where dilation of preexisting lumina generally occurs without intraluminal epithelial proliferation, it is clear that these processes maintaining the tree-like structure are different from cancers with presumed neoductgenesis. Threedimensional analysis of such cases further reinforces the lack of normal distribution of ducts and acini in such tumors [84]. This "disturbed arborization" [87; 88] could be the result of a disturbed alveolar switch [129], a hormonally driven physiologic mechanism responsible for the development of acini from ductal epithelium. Our report indicates that the proposed neoducts are also devoid of elastic coating, resembling acini in this respect.

There were more structures that could not be reliably classified as ducts or acini than structures corresponding to neoducts on the basis of the neoduct scoring applied to the individual structures. These unclassifiable structures were generally devoid of elastic fibers. Cases that could not be classified as representing neoductgenesis on the basis of the overall score also contained such elastic fibreless unclassifiable structures. It could happen that more of these comedo necrotic structures correspond to neoducts than those identified as neoducts on the basis of the individually (per structure) applied score. Of the two other possible explanations, namely that the unclassifiable structures correspond to acini (originally lacking elastic fibers) or ducts losing their elastic coating, the first seems unlikely due to the diffuse and non-lobular distribution of these structures (this is why they could not be classified even as likely acini), whereas the second is also questionable on the basis of the distribution (there 
are too many of them clustered close to each other, not allowing their classification even as likely ducts).

Our study therefore identifies possible neoducts as structures devoid of elastic periductal fibers and most of the structures that could not be classified as (likely) ducts or (likely) acini on the basis of distribution patterns as similarly devoid of elastic fibers and possibly also as neoducts. The use of elastic stains may probably be an aid in the study of neoductgenesis.

\section{CONCLUSIONS}

Our work is the largest series of TNBC analyzed for the expression of 4 markers of mammary origin, moreover the series includes exclusively TNBC of a distinct subtype, namely tumors expressing CK5 and therefore most likely to coincide with basal-like breast carcinomas.

The expression of GATA3, MG, GCDFP-15 and NY-BR-1 is lower in TNBCs than in breast carcinomas in general. Although these markers may be positive in different other tumors, by using them, a subset of basal-like TNBC-s can be identified as of mammary origin. Though the positive staining supports a breast origin, negativity for all markers does not exclude this.

Therefore we suggest using GATA-3, MG and GCDFP-15 as an IHC panel to establish breast origin when ER and PR are negative. One should be prepared to find a relatively high number of basal-like TNBCs to be negative for all the studied breast markers.

Our paper is the first study describing the distribution of regression heterogeneity in the tumor bed according to molecular subtypes in breast cancer after PST. Our findings suggest that regression may be inhomogeneous in half of the cases, and it does not seem to be related to any molecular subtype, therefore the evaluation of the whole tumor bed is recommended for the best assessment of regression. Taking limited number of core needle biopsies from the tumor bed might not be sufficient in all cases for following the regression after PST. 
The neoplastic "monster" cells are related to PST including taxanes, and may cause upgrading in tumors with non-high grade nuclei at the start of PST. Their effect on gene amplification patterns has not been tested, but may also be of concern.

Despite the attractiveness of a preferential regression (or non-regression) in tumor draining lymph nodes (SLNs which seem to be immunosuppressed and at the same time are the sites of TRL), the evidence gathered from the limited number of cases available suggests that there is no obvious difference in the degree of regressive histological changes shown by SLNs and non-SLNs. Therefore, this phenomenon may not be a major contributor to the somewhat higher false negative rate of SLN biopsy after PST

The theory of neoductgenesis suggests that cases of diffuse DCIS with comedo like necrosis and amorphous calcification are characterized by the outgrowth of new branches, i.e. new ducts, neoducts from the ductal tree, representing a pushing type infiltration. This may explain the worse outcome of these cases compared to patients with breast cancer lacking diffuse DCIS.

Our study identifies possible neoducts as structures devoid of elastic periductal fibers and most of the structures that could not be classified as (likely) ducts or (likely) acini on the basis of distribution patterns as similarly devoid of elastic fibers and possibly also as neoducts. The use of elastic stains may probably be an aid in the study of neoductgenesis.

\section{ACKNOWLEDGEMENTS}

I greatly appreciate all the support and scientific guidance of my supervisor Professor Gábor Cserni from the Department of Pathology, University of Szeged and Head of the Department of Pathology, Bács-Kiskun County Teaching Hospital in Kecskemét.

I express special thanks to Professor Béla Iványi and László Tiszlavicz, Heads of the Department of Pathology, University of Szeged at the time of writing the articles, who provided accomplished working conditions at the department.

I also thank to Dr. Tibor Hortobágyi for his support in the last phase of this thesis.

I am grateful to my tutors László Kaizer, Sándor Hamar and András Vörös who introduced me to challenges of breast histopathology. 
I would like to express my gratitude for the staff members of the breast tumor board: Professor Zsuzsanna Kahán, Professor György Lázár, Attila Paszt, Zsolt Simonka, Katalin Ormándi, Csilla Hoffmann, Alíz Nikolényi, Orsolya Rusz, Professor Gábor Cserni, Sándor Hamar, László Kaizer, András Vörös, and Mihály Dezső (photographic technician at the Department of Pathology, University of Szeged). Their high quality work helped this dissertation to come into existence.

I am thankful to my family, my fiancée and friends for support and subservience.

The studies forming the basis of this thesis were partly funded by the National Research, Development and Innovation Office grant GINOP-2.3.2-15-2016-00020. 


\section{REFERENCES}

1. DeSantis C, Ma J, Bryan L, Jemal A. Breast cancer statistics, 2013. CA Cancer J Clin 2013; 64: 52-62. doi: 10.3322/caac.21203

2. Malvezzi M, Carioli G, Bertuccio P, Rosso T, Boffetta P, Levi F, La Vecchia C, Negri E. European cancer mortality predictions for the year 2016 with focus on leukaemias. Ann Oncol 2016; 27: 725-731. doi: 10.1093/annonc/mdw022

3. https://www.ncbi.nlm.nih.gov/pubmed/?term=breast+cancer Accessed on 30th of September 2018.

4. Lakhani SR, Ellis IO, Schnitt SJ, Tan PH, van de Vijver MJ. WHO Classification of Tumours of the Breast, 4th edition, International Agency for Research on Cancer, 2012; Lyon

5. Elston CW, Ellis IO. (editors). The Breast. Systemic Pathology. 3rd edition, Churchill Livingstone. 1998; Edinburgh, pp. 239-247.

6. Amin MB, Edge S., Greene F, Byrd DR, Brookland RK, Washington MK, Gershenwald JE, Compton CC, Hess KR, Sullivan DC, Jessup JM, Brierley JD, Gaspar LE, Schilsky RL, Balch CM, Winchester DP, Asare EA, Madera M, Gress DM, Meyer LR. (editors) AJCC Cancer staging manual. 8th edition, Springer, 2017; New York, pp. 587-628.

7. Brierley JD, Gospodarowicz M, Wittekind C. (editors) UICC TNM classification of malignant tumours. 8th edition, Wiley-Blackwell, 2017; Chichester

8. Perou CM, Sørlie T, Eisen MB, van de Rijn M, Jeffrey SS, Rees CA, Pollack JR, Ross DT, Johnsen H, Akslen LA, Fluge O, Pergamenschikov A, Williams C, Zhu SX, Lønning PE, Børresen-Dale AL, Brown PO, Botstein D. Molecular portraits of human breast tumours. Nature 2000; 406: 747-752.

9. Nielsen TO, Perou CM. CCR 20th Anniversary Commentary: The development of breast cancer molecular subtyping. Clin Cancer Res 2015; 21: 1779-1781. doi: 10.1158/1078-0432.CCR-14-2552 
10. Zombori T, Lehóczky L, Cserni B, Nyári T, Cserni G. Evaluation of anatomic and prognostic stages of breast cancer according to the 8th edition of the TNM staging system - Retrospective analysis based on data from deceased patients once diagnosed with breast cancer. Orv Hetil. 2017;158:1373-1381. doi: 10.1556/650.2017.30849. [Hungarian]

11. Hernandez BY, Green MD, Cassel KD, Pobutsky AM, Vu V, Wilkens LR. Preview of Hawaii cancer facts and figures. Hawaii Med J 2010; 69: 223-224.

12. Huo L, Gong Y, Guo M, Gilcrease MZ, Wu Y, Zhang H, Zhang J, Resetkova E, Hunt KK, Deavers MT. GATA-binding protein 3 enhances the utility of gross cystic disease fluid protein-15 and mammaglobin $\mathrm{A}$ in triple-negative breast cancer by immunohistochemistry. Histopathology 2015; 67: 245-254. doi: 10.1111/his.12645

13. Deftereos G, Sanguino Ramirez AM, Silverman JF, Krishnamurti U. GATA3 immunohistochemistry expression in histologic subtypes of primary breast carcinoma and metastatic breast carcinoma cytology. Am J Surg Pathol 2015; 39: 1282-1289. doi: 10.1097/PAS.0000000000000505

14. Chou J, Provot S, Werb Z. GATA3 in development and cancer differentiation: cells GATA have it! J Cell Physiol 2010; 222: 42-49. doi: 10.1002/jcp.21943

15. Esheba GE, Longacre TA, Atkins KA, Higgins JP. Expression of the urothelial differentiation markers GATA3 and placental S100 (S100P) in female genital tract transitional cell proliferations. Am J Surg Pathol 2009; 33: 347-353.

16. Liu H, Shi J, Wilkerson ML, Lin F. Immunohistochemical evaluation of GATA3 expression in tumors and normal tissues: a useful immunomarker for breast and urothelial carcinomas. Am J Clin Pathol 2012; 138: 57-64. doi: 10.1309/AJCP5UAFMSA9ZQBZ

17. Ordonez NG. Value of GATA3 immunostaining in tumor diagnosis: a review. Adv Anat Pathol 2013; 20: 352-360. doi: 10.1097/PAP.0b013e3182a28a68

18. Miettinen M, McCue PA, Sarlomo-Rikala M, Rys J, Czapiewski P, Wazny K, Langfort R, Waloszczyk P, Biernat W, Lasota J, Wang Z. GATA3: a multispecific 
but potentially useful marker in surgical pathology: a systematic analysis of 2500 epithelial and nonepithelial tumors. Am J Surg Pathol 2014; 38: 13-22. doi: 10.1097/PAS.0b013e3182a0218f

19. Voduc D, Cheang M, Nielsen T. GATA-3 expression in breast cancer has a strong association with estrogen receptor but lacks independent prognostic value. Cancer Epidemiol Biomarkers Prev 2008; 17: 365-373. doi: 10.1158/1055-9965.EPI-061090

20. Hoch RV, Thompson DA, Baker RJ, Weigel RJ. GATA-3 is expressed in association with estrogen receptor in breast cancer. Int J Cancer 1999; 84:122-128.

21. Tominaga N, Naoi Y, Shimazu K, Nakayama T, Maruyama N, Shimomura A, Kim SJ, Tamaki Y, Noguchi S. Clinicopathological analysis of GATA3-positive breast cancers with special reference to response to neoadjuvant chemotherapy. Ann Oncol 2012; 23:3051-3057. doi: 10.1093/annonc/mds120

22. Albergaria A, Paredes J, Sousa B, Milanezi F, Carneiro V, Bastos J, Costa S, Vieira D, Lopes N, Lam EW, Lunet N, Schmitt F. Expression of FOXA1 and GATA-3 in breast cancer: the prognostic significance in hormone receptor-negative tumours. Breast Cancer Res 2009; 11:R40. doi: 10.1186/bcr2327

23. Parikh P, Palazzo JP, Rose LJ, Daskalakis C, Weigel RJ. GATA-3 expression as a predictor of hormone response in breast cancer. J Am Coll Surg 2005; 200: 705-710.

24. Mehra R, Varambally S, Ding L, Shen R, Sabel MS, Ghosh D, Chinnaiyan AM, Kleer CG. Identification of GATA3 as a breast cancer prognostic marker by global gene expression meta-analysis. Cancer Res 2005; 65: 11259-11264.

25. Cimino-Mathews A, Subhawong AP, Illei PB, Sharma R, Halushka MK, Vang R, Fetting JH, Park BH, Argani P. GATA3 expression in breast carcinoma: utility in triple-negative, sarcomatoid, and metastatic carcinomas. Hum Pathol 2013; 44: 13411349. doi: 10.1016/j.humpath.2012.11.003 
26. Ciocca V, Daskalakis C, Ciocca RM, Ruiz-Orrico A, Palazzo JP. The significance of GATA3 expression in breast cancer: a 10-year follow-up study. Hum Pathol 2009; 40: 489-495. doi: 10.1016/j.humpath.2008.09.010

27. Jacquemier J, Charafe-Jauffret E, Monville F, Esterni B, Extra JM, Houvenaeghel G, Xerri L, Bertucci F, Birnbaum D. Association of GATA3, P53, Ki67 status and vascular peritumoral invasion are strongly prognostic in luminal breast cancer. Breast Cancer Res 2009; 11:R23. doi: 10.1186/bcr2249

28. Demir H, Turna H, Can G, Ilvan S. Clinicopathologic and prognostic evaluation of invasive breast carcinoma molecular subtypes and GATA3 expression. J Buon 2010; 15: 774-782.

29. Watson MA, Fleming TP. Mammaglobin, a mammary-specific member of the uteroglobin gene family, is overexpressed in human breast cancer. Cancer Res 1996; 56: 860-865.

30. Watson MA, Darrow C, Zimonjic DB, Popescu NC, Fleming TP. Structure and transcriptional regulation of the human mammaglobin gene, a breast cancer associated member of the uteroglobin gene family localized to chromosome 11q13. Oncogene 1998; 16: 817-824.

31. Han JH, Kang Y, Shin HC, Kim HS, Kang YM, Kim YB, Oh SY. Mammaglobin expression in lymph nodes is an important marker of metastatic breast carcinoma. Arch Pathol Lab Med 2003; 127: 1330-1334.

32. Bhargava R, Beriwal S, Dabbs DJ. Mammaglobin vs GCDFP-15: an immunohistologic validation survey for sensitivity and specificity. Am J Clin Pathol 2007; 127: 103-113.

33. Zafrakas M, Petschke B, Donner A, Fritzsche F, Kristiansen G, Knüchel R, Dahl E. Expression analysis of mammaglobin A (SCGB2A2) and lipophilin B (SCGB1D2) in more than 300 human tumors and matching normal tissues reveals their coexpression in gynecologic malignancies. BMC Cancer 2006; 6: 88. 
34. Sasaki E, Tsunoda N, Hatanaka Y, Mori N, Iwata H, Yatabe Y. Breast-specific expression of MGB1/mammaglobin: an examination of 480 tumors from various organs and clinicopathological analysis of MGB1-positive breast cancers. Mod Pathol 2007; 20: 208-214.

35. Wang Z, Spaulding B, Sienko A, Liang Y, Li H, Nielsen G, Yub Gong G, Ro JY, Jim Zhai Q. Mammaglobin, a valuable diagnostic marker for metastatic breast carcinoma. Int J Clin Exp Pathol 2009; 2: 384-389.

36. Onuma K, Dabbs DJ, Bhargava R. Mammaglobin expression in the female genital tract: immunohistochemical analysis in benign and neoplastic endocervix and endometrium. Int J Gynecol Pathol 2008; 27: 418-425. doi: 10.1097/PGP.0b013e31815d05ec

37. Al-Joudi FS, Kaid FA, Ishak I, Mohamed N, Osman K, Alias IZ. Expression of human mammaglobin and clinicopathologic correlations in breast cancer: the findings in Malaysia. Indian J Pathol Microbiol 2011 ; 54: 284-289. doi: $10.4103 / 0377-4929.81596$

38. Lewis GH, Subhawong AP, Nassar H, Vang R, Illei PB, Park BH, Argani P. Relationship between molecular subtype of invasive breast carcinoma and expression of gross cystic disease fluid protein 15 and mammaglobin. Am J Clin Pathol 2011; 135: 587-591. doi: 10.1309/AJCPMFR6OA8ICHNH

39. Fritzsche FR, Thomas A, Winzer KJ, Beyer B, Dankof A, Bellach J, Dahl E, Dietel M, Kristiansen G. Co-expression and prognostic value of gross cystic disease fluid protein 15 and mammaglobin in primary breast cancer. Histol Histopathol 2007; 22: 1221-1230.

40. Haagensen DE Jr, Mazoujian G, Holder WD Jr, Kister SJ, Wells SA Jr. Evaluation of a breast cyst fluid protein detectable in the plasma of breast carcinoma patients. Ann Surg 1977; 185: 279-285.

41. Wick MR, Lillemoe TJ, Copland GT, Swanson PE, Manivel JC, Kiang DT. Gross cystic disease fluid protein-15 as a marker for breast cancer: immunohistochemical 
analysis of 690 human neoplasms and comparison with alpha-lactalbumin. Hum Pathol 1989; 20: 281-287.

42. Park SY, Kim BH, Kim JH, Lee S, Kang GH. Panels of immunohistochemical markers help determine primary sites of metastatic adenocarcinoma. Arch Pathol Lab Med 2007; 131: 1561-1567.

43. Jäger D, Stockert E, Güre AO, Scanlan MJ, Karbach J, Jäger E, Knuth A, Old LJ, Chen YT. Identification of a tissue-specific putative transcription factor in breast tissue by serological screening of a breast cancer library. Cancer Res 2001; 61: 20552061.

44. Jäger D, Filonenko V, Gout I, Frosina D, Eastlake-Wade S, Castelli S, Varga Z, Moch H, Chen YT, Busam KJ, Seil I, Old LJ, Nissan A, Frei C, Gure AO, Knuth A, Jungbluth AA. NY-BR-1 is a differentiation antigen of the mammary gland. Appl Immunohistochem Mol Morphol 2007; 15: 77-83.

45. Giger OT, Lacoste E, Honegger C, Padberg B, Moch H, Varga Z. Expression of the breast differentiation antigen NY-BR-1 in a phyllodes tumor of the vulva. Virchows Arch 2007; 450: 471-474.

46. Varga Z, Theurillat JP, Filonenko V, Sasse B, Odermatt B, Jungbluth AA, Chen YT, Old LJ, Knuth A, Jäger D, Moch H. Preferential nuclear and cytoplasmic NY-BR-1 protein expression in primary breast cancer and lymph node metastases. Clin Cancer Res 2006; 12: 2745-2751.

47. Theurillat JP, Zürrer-Härdi U, Varga Z, Storz M, Probst-Hensch NM, Seifert B, Fehr MK, Fink D, Ferrone S, Pestalozzi B, Jungbluth AA, Chen YT, Jäger D, Knuth A, Moch H. NY-BR-1 protein expression in breast carcinoma: a mammary gland differentiation antigen as target for cancer immunotherapy. Cancer Immunol Immunother 2007; 56: 1723-1731.

48. Seil I, Frei C, Sültmann H, Knauer SK, Engels K, Jäger E, Zatloukal K, Pfreundschuh M, Knuth A, Tseng-Chen Y, Jungbluth AA, Stauber RH, Jäger D. The differentiation antigen NY-BR-1 is a potential target for antibody-based therapies in breast cancer. Int J Cancer 2007; 120: 2635-2642. 
49. Woodard AH, Yu J, Dabbs DJ, Beriwal S, Florea AV, Elishaev E, Davison JM, Krasinskas AM, Bhargava R. NY-BR-1 and PAX8 immunoreactivity in breast, gynecologic tract, and other CK7+ carcinomas: potential use for determining site of origin. Am J Clin Pathol 2011; 136: 428-435. doi: 10.1309/AJCPUFNMEZ3MK1BK

50. Balafoutas D, zur Hausen A, Mayer S, Hirschfeld M, Jaeger M, Denschlag D, Gitsch G, Jungbluth A, Stickeler E. Cancer testis antigens and NY-BR-1 expression in primary breast cancer: prognostic and therapeutic implications. BMC Cancer 2013; 13: 271. doi: 10.1186/1471-2407-13-271

51. Liu H. Application of immunohistochemistry in breast pathology: a review and update. Arch Pathol Lab Med 2014; 138: 1629-1642. doi: 10.5858/arpa.2014-0094RA

52. Mesa-Tejada R, Palakodety RB, Leon JA, Khatcherian AO, Greaton CJ. Immunocytochemical distribution of a breast carcinoma associated glycoprotein identified by monoclonal antibodies. Am J Pathol 1988; 130: 305-314.

53. Loy TS, Chapman RK, Diaz-Arias AA, Bulatao IS, Bickel JT. Distribution of BCA225 in adenocarcinomas. An immunohistochemical study of 446 cases. Am J Clin Pathol 1991; 96: 326-329.

54. Thompson AM, Moulder-Thompson SL. Neoadjuvant treatment of breast cancer. Ann Oncol 2012; 10: x231-6. https://doi.org/10.1093/annonc/mds324

55. Royal College of Pathologists of Australasia. Invasive Breast cancer structured $\begin{array}{llll}\text { reporting } & \text { (2nd 2012; }\end{array}$ https://www.rcpa.edu.au/getattachment/7b70b3e5-5dca-403f-893e638815f487b1/Protocol-invasive-breast-cancer.aspx. Accessed 26 June 2018

56. Lambein K, Van de Vijver K, Faverly D, Colpaert C. Belgian guidelines for laboratory handling and pathology reporting of breast carcinoma after neoadjuvant therapy. Belg J Clin Oncol 2011; 5: 144-153.

57. Arbeitsgemeinschaft Gynäkologische Onkologie Studiengruppe (AGO) https://www.ago-online.de/fileadmin/downloads/leitlinien/mamma/2018- 
03/EN/Gesamt_PDF_Englisch/Updated_Guidelines_2018.pdf. Accessed 26 June 2018

58. NHS Breast Screening Program. Pathology reporting of breast disease: A joint document incorporating the third edition of the NHS Breast Screening Programs Guidelines for pathology reporting in breast cancer screening and the second edition of the Royal College of Pathologists' Minimum dataset for breast cancer histopathology. NHSBSP Publication 2005; No 58. NHS Cancer Screening Programs jointly with the Royal College of Pathologists.

59. Integraal Kankercentrum Nederland. Beoordeling na neoadjuvante chemo- of endocriene therapie. 2012; http://www.oncoline.nl/breastcancer 2012. Accessed 26 June 2018

60. College of American Pathologists. Protocol for the examination of specimens from patients with invasive carcinoma of the breast. http://www.cap.org/ShowProperty?nodePath=/UCMCon/Contribution\%20Fold ers/WebContent/pdf/cp-breast-invasive-16protocol-3300.pdf Accessed 36 June 2018

61. Cserni G, Kulka J, Francz M, Járay B, Kálmán E, Kovács I, Krenács T, Udvarhelyi N, Vass L. Pathological diagnosis, work-up and reporting of breast cancer. Recommendations of the 3rd Hungarian Consensus Conference on Breast Cancer. Magy Onkol 2016; 60: 209-28. [Hungarian]

62. Park CK, Jung WH, Koo JS. Pathologic evaluation of breast cancer after neoadjuvant therapy. J Pathol Transl Med 2016; 50: 173-80. https://doi.org/10.4132/jptm.2016.02.02.

63. Provenzano E, Bossuyt V, Viale G, Cameron D, Badve S, Denkert C, MacGrogan G, Penault-Llorca F, Boughey J, Curigliano G, Dixon JM, Esserman L, Fastner G, Kuehn T, Peintinger F, von Minckwitz G, White J, Yang W, Symmans WF. Residual Disease Characterization Working Group of the Breast International Group-North American Breast Cancer Group Collaboration. Standardization of pathologic evaluation and reporting of postneoadjuvant specimens in clinical trials of breast 
cancer: recommendations from an international working group. Mod Pathol 2015; 28: 1185-201. https://doi.org/10.1038/modpathol.2015.74.

64. Tot $\mathrm{T}$. The role of large-format histopathology in assessing subgross morphological prognostic parameters: a single institution report of 1000 consecutive breast cancer cases. Int J Breast Cancer 2012; 2012: 395415. https://doi.org/10.1155/2012/395415.

65. U.S. Food and Drug Administration. Guidance for Industry: Pathological complete response in neoadjuvant treatment of high-risk early-stage breast cancer: use as an endpoint to support accelerated approval. 2014; http://www.fda.gov/downloads/Drugs/GuidanceComplianceRegulatoryInformation/ Guidances/UCM305501.pdf Accessed 26 June 2018

66. Cortazar P, Zhang L, Untch M, Mehta K, Costantino JP, Wolmark N, Bonnefoi H, Cameron D, Gianni L, Valagussa P, Swain SM, Prowell T, Loibl S, Wickerham DL, Bogaerts J, Baselga J, Perou C, Blumenthal G, Blohmer J, Mamounas EP, Bergh J, Semiglazov V, Justice R, Eidtmann H, Paik S, Piccart M, Sridhara R, Fasching PA, Slaets L, Tang S, Gerber B, Geyer CE Jr, Pazdur R, Ditsch N, Rastogi P, Eiermann W, von Minckwitz G. Pathological complete response and long-term clinical benefit in breast cancer: the CTNeoBC pooled analysis. Lancet 2014; 384: 164-72. https://doi.org/10.1016/S0140-6736(13)62422-8.

67. von Minckwitz G, Untch M, Blohmer JU, Costa SD, Eidtmann H, Fasching PA, Gerber B, Eiermann W, Hilfrich J, Huober J, Jackisch C, Kaufmann M, Konecny GE, Denkert C, Nekljudova V, Mehta K, Loibl S. Definition and impact of pathologic complete response on prognosis after neoadjuvant chemotherapy in various intrinsic breast cancer subtypes. J Clin Oncol 2012; 30: 1796-804. https://doi.org/10.1200/JCO.2011.38.8595.

68. Mamounas EP, Anderson SJ, Dignam JJ, Bear HD, Julian TB, Geyer CE Jr, Taghian A, Wickerham DL, Wolmark N. Predictors of locoregional recurrence after neoadjuvant chemotherapy: results from combined analysis of National Surgical Adjuvant Breast and Bowel Project B-18 and B-27. J Clin Oncol 2012; 30: 3960-6. https://doi.org/10.1200/JCO.2011.40.8369. 
69. Pinder SE, Provenzano E, Earl H, Ellis IO. Laboratory handling and histology reporting of breast specimens from patients who have received neoadjuvant chemotherapy. Histopathology 2007; 50: 409-17. https://doi.org/10.1111/j.13652559.2006.02419.x

70. Denkert C, Schickling O, von Minckwitz G. Preoperative chemotherapy in breast cancer and the development of new predictive markers. Verh Dtsch Ges Pathol 2006; 90: 114-23. [German]

71. Sataloff DM, Mason BA, Prestipino AJ, Seinige UL, Lieber CP, Baloch Z. Pathologic response to induction chemotherapy in locally advanced carcinoma of the breast: a determinant of outcome. J Am Coll Surg 1995; 180: 297-306.

72. Greenall MJ. Why I favour axillary node sampling in the management of breast cancer. Eur J Surg Oncol 1995; 21: 2-5

73. Cserni G. Estimating the overlap between sentinel lymph nodes and axillary node samples in breast cancer. Pathol Oncol Res 1999; 5: 129-133.

74. Qian CN, Berghuis B, Tsarfaty G, Bruch M, Kort EJ, Ditlev J, Tsarfaty I, Hudson E, Jackson DG, Petillo D, Chen J, Resau JH, Teh BT. Preparing the "soil": the primary tumor induces vasculature reorganization in the sentinel lymph node before the arrival of metastatic cancer cells. Cancer Res 2006; 66: 10365-10376.

75. Schüle JM, Bergkvist L, Håkansson L, Gustafsson B, Håkansson A. CD28 expression in sentinel node biopsies from breast cancer patients in comparison with CD3-zeta chain expression. J Transl Med 2004; 2: 45 doi:10.1186/1479-5876-2-45

76. Schüle J, Bergkvist L, Håkansson L, Gustafsson B, Håkansson A. Down-regulation of the CD3-zeta chain in sentinel node biopsies from breast cancer patients. Breast Cancer Res Treat 2002; 74: 33-40

77. Cochran AJ, Huang RR, Lee J, , Itakura E, Leong SP, Essner R. Tumour-induced immune modulation of sentinel lymph nodes. Nat Rev Immunol 2006; 6: 659-670

78. Straver ME, Loo CE, Alderliesten T, Rutgers EJ, Vrancken Peeters MT. Marking the axilla with radioactive iodine seeds (MARI procedure) may reduce the need for 
axillary dissection after neoadjuvant chemotherapy for breast cancer. Br J Surg 2010; 97: 1226-1231.

79. Tot T. Normal breast tissue or Fibrocystic change? In: Tot T, Tabár L, Dean PB (eds) Practical breast pathology, 2nd edn. 2014; Thieme, Stuttgart, pp 1-23

80. Azzopardi JG. Cystic disease: Duct ectasia: Fat Necrosis: 'Fibrous disease of the breast'. In Azzopardi JG (ed) Problems in breast pathology. 1979; Saunders, London, pp 57-91

81. Fechner RE. Ductal carcinoma involving the lobule of the breast. A source of confusion with lobular carcinoma in situ. Cancer 1971; 28: 274-281

82. Kerner H, Lichtig C. Lobular cancerization: incidence and differential diagnosis with lobular carcinoma in situ of breast. Histopathology 1986; 10: 621-629

83. Tabár L, Tony Chen HH, Amy Yen MF, Tot T, Tung TH, Chen LS, Chiu YH, Duffy SW, Smith RA. Mammographic tumor features can predict long-term outcomes reliably in women with 1-14-mm invasive breast carcinoma. Cancer 2004; 101: $1745-1759$

84. Tabár L, Tot T, Dean P. Casting type calcifications: sign of a subtype with deceptive features. 2007; Thieme, Stuttgart

85. Hilson JB, Schnitt SJ, Collins LC. Phenotypic alterations in ductal carcinoma in situassociated myoepithelial cells: biologic and diagnostic implications. Am J Surg Pathol 2009; 33: 227-232.

86. Kővári B, Szász AM, Kulka J, Marušić Z, Šarčević B, Tiszlavicz L, Cserni G. Evaluation of p40 as a myoepithelial marker in different breast lesions. Pathobiology 2015; 82:165-170. doi: 10.1159/000375127

87. Tot T, Tabár L. Mammographic-pathologic correlation of ductal carcinoma in situ of the breast using two- and three-dimensional large histologic sections. Semin Breast Dis 2005; 8: 144-151.

88. Tot T. DCIS, cytokeratins, and the theory of the sick lobe. Virchows Arch 2005; 447: $1-8$. 
89. Tabár L, Chen HH, Duffy SW, Yen MF, Chiang CF, Dean PB, Smith RA. A novel method for prediction of long-term outcome of women with T1a, T1b, and 10-14 mm invasive breast cancers: a prospective study. Lancet 2000; 355: 429-433.

90. Zunzunegui RG, Chung MA, Oruwari J, Golding D, Marchant DJ, Cady B. Castingtype calcifications with invasion and high-grade ductal carcinoma in situ: a more aggressive disease? Arch Surg 2003; 138: 537-540.

91. Pálka I, Ormándi K, Gaál S, Boda K, Kahán Z. Casting-type calcifications on the mammogram suggest a higher probability of early relapse and death among high-risk breast cancer patients. Acta Oncol 2007; 46: 1178-1183.

92. Bennett RL, Evans AJ, Kutt E, Record C, Bobrow LG, Ellis IO, Hanby A, Moss SM. Pathological and mammographic prognostic factors for screen detected cancers in a multi-centre randomised, controlled trial of mammographic screening in women from age 40 to 48 years. Breast 2011; 20: 525-528 doi: 10.1016/j.breast.2011.05.008.

83. James JJ, Evans AJ, Pinder SE, Macmillan RD, Wilson AR, Ellis IO. Is the presence of mammographic comedo calcification really a prognostic factor for small screendetected invasive breast cancers? Clin Radiol 2003; 58: 54-62.

94. Månsson E, Bergkvist L, Christenson G, Persson C, Wärnberg F. Mammographic casting-type calcifications is not a prognostic factor in unifocal small invasive breast cancer: a population-based retrospective cohort study. J Surg Oncol 2009; 100: 670674.

95. Zhou W, Sollie T, Tot T, Blomqvist C, Abdsaleh S, Liljegren G, Wärnberg F. Ductal Breast Carcinoma In Situ: Mammographic Features and Its Relation to Prognosis and Tumour Biology in a Population Based Cohort. Int J Breast Cancer 2017; 2017: 4351319. doi: $10.1155 / 2017 / 4351319$

96. Zhou W, Sollie T, Tot T, Pinder SE, Amini RM, Blomqvist C, Fjällskog ML, Christensson G, Abdsaleh S, Wärnberg F. Breast cancer with neoductgenesis: histopathological criteria and its correlation with mammographic and tumour features. Int J Breast Cancer 2014; 2014: 581706. doi: 10.1155/2014/581706. 
97. Wells CA, Amendoeira I, Bellocq JP, Bianchi S, Boecker W, Borisch B, Bruun Rasmussen B, Callagy GM, Chmielik E, Cordoba A, Cserni G, Decker T, DeGaetano J, Drijkoningen M, Ellis IO, Faverly DR, Foschini MP, Frković-Grazio S, Grabau D, Heikkilä P, Iacovou E, Jacquemier J, Kaya H, Kulka J, Lacerda M, Liepniece-Karele I, Martinez-Penuela J, Quinn CM, Rank F, Regitnig P, Reiner-Concin A, Sapino A, Tot T, Van Diest PJ, Varga Z, Wesseling J, Zolota V, Zozaya-Alvarez E. Pathology update. Quality assurance guidelines for pathology. In: Perry N, Broeders M, de Wolf C, Törnberg S, Holland R, von Karsa L. (editors) European guidelines for quality assurance in breast cancer screening and diagnosis. Supplements. 4th edition, European Commission, Office for Official Publications of the European Union, 2012; Luxembourg, pp. 73-120.

98. Goldhirsch A, Winer EP, Coates AS, Gelber RD, Piccart-Gebhart M, Thürlimann B, Senn HJ; Panel members. Personalizing the treatment of women with early breast cancer: highlights of the St Gallen International expert consensus on the primary therapy of early breast cancer 2013. Ann Oncol 2013; 24: 2206-23. https://doi.org/10.1093/annonc/mdt303.

99. Giordano SH, Temin S, Chandarlapaty S, Crews JR, Esteva FJ, Kirshner JJ, Krop IE, Levinson J, Lin NU, Modi S, Patt DA, Perlmutter J, Ramakrishna N, Winer EP, Davidson NE. Systemic therapy for patients with advanced human epidermal growth factor receptor 2-positive breast cancer: ASCO Clinical practice guideline update. J Clin Oncol 2018; 36: 2736-2740. doi: 10.1200/JCO.2018.79.2697.

100. Amendoeira I, Apostolikas N, Bellocq JP, Bianchi S, Boecker W, Borisch B, Bussolati G, Connolly CE, Cserni G, Decker T, Dervan P, Drijkoningen M, Ellis IO, Elston CW, Eusebi V, Faverly D, Heikkila P, Holland R, Kerner H, Kulka J, Jacquemier J, Lacerda M, Martinez-Penuela J, De Miguel C, Nordgren H, Peterse JL, Rank F, Regitnig P, Reiner A, Sapino A, Sigal-Zafrani B, Tanous AM, Thorstenson S, Zozaya E, Wells CA; EC Working Group on Breast Screening Pathology. (Wells CA ed). Quality assurance guidelines for pathology. In: Perry N, Broeders M, de Wolf C, Törnberg S, Holland R, von Karsa L. (editors) European guidelines for quality assurance in breast cancer screening and diagnosis, 4th edition, European Comission, 2006; Luxemburg, pp 219-311. 
101. Abramson VG, Lehmann BD, Ballinger TJ, Pietenpol JA. Subtyping of triplenegative breast cancer: implications for therapy. Cancer 2015; 121: 8-16. doi: $10.1002 /$ cncr.28914

102. Vranic S, Schmitt F, Sapino A, Costa JL, Reddy S, Castro M, Gatalica Z. Apocrine carcinoma of the breast: a comprehensive review. Histol Histopathol 2013; 28: 1393 1409. doi: 10.14670/HH-28.1393

103. Nielsen TO, Hsu FD, Jensen K, Cheang M, Karaca G, Hu Z, Hernandez-Boussard T, Livasy C, Cowan D, Dressler L, Akslen LA, Ragaz J, Gown AM, Gilks CB, van de Rijn M, Perou CM. Immunohistochemical and clinical characterization of the basallike subtype of invasive breast carcinoma. Clin Cancer Res 2004; 10: 5367-5374.

104. Sasahara M, Matsui A, Ichimura Y, Hirakata Y, Murata Y, Marui E. Overexpression of androgen receptor and forkhead-box A1 protein in apocrine breast carcinoma. Anticancer Res 2014; 34: 1261-1267.

105. Kővári B, Rusz O, Schally AV, Kahán Z, Cserni G. Differential immunostaining of various types of breast carcinomas for growth hormone-releasing hormone (GHRH) receptor - Apocrine epithelium and carcinomas emerging as uniformly positive. APMIS 2014; 122: 824-831. doi: 10.1111/apm.12224

106. Ordonez NG, Sahin AA. Diagnostic utility of immunohistochemistry in distinguishing between epithelioid pleural mesotheliomas and breast carcinomas: a comparative study. Hum Pathol 2014; 45: 1529-1540. doi: 10.1016/j.humpath.2014.03.006

107. Krings G, Nystrom M, Mehdi I, Vohra P, Chen YY. Diagnostic utility and sensitivities of GATA3 antibodies in triple-negative breast cancer. Hum Pathol 2014; 45: 2225-2232. doi: 10.1016/j.humpath.2014.06.022

108. Kaufmann M, von Minckwitz G, Smith R, Valero V, Gianni L, Eiermann W, Howell A, Costa SD, Beuzeboc P, Untch M, Blohmer JU, Sinn HP, Sittek R, Souchon R, Tulusan AH, Volm T, Senn HJ. International expert panel on the use of primary (preoperative) systemic treatment of operable breast cancer: review and recommendations. J Clin Oncol 2003; 21: 2600-8. doi:10.1200/JCO.2003.01.136 
109. Kaufmann M, Hortobagyi GN, Goldhirsch A, Scholl S, Makris A, Valagussa P, Blohmer JU, Eiermann W, Jackesz R, Jonat W, Lebeau A, Loibl S, Miller W, Seeber S, Semiglazov V, Smith R, Souchon R, Stearns V, Untch M, von Minckwitz G. Recommendations from an international expert panel on the use of neoadjuvant (primary) systemic treatment of operable breast cancer: an update. J Clin Oncol 2006; 24: 1940-9. doi:10.1200/JCO.2005.02.6187

110. von Minckwitz G, Blohmer JU, Raab G, Löhr A, Gerber B, Heinrich G, Eidtmann H, Kaufmann M, Hilfrich J, Jackisch C, Zuna I, Costa SD; German Breast Group. In vivo chemosensitivity-adapted preoperative chemotherapy in patients with earlystage breast cancer: the GEPARTRIO pilot study. Ann Oncol 2005; 16:56-63. doi:10.1093/annonc/mdi001

111. Chollet P, Amat S, Cure H, de Latour M, Le Bouedec G, Mouret-Reynier MA, Ferriere JP, Achard JL, Dauplat J, Penault-Llorca F. Prognostic significance of a complete pathological response after induction chemotherapy in operable breast cancer. Br J Cancer 2002; 86: 1041-6. doi:10.1038/sj.bjc.6600210

112. Marinovich ML, Macaskill P, Irwig L, Sardanelli F, Mamounas E, von Minckwitz G, Guarneri V, Partridge SC, Wright FC, Choi JH, Bhattacharyya M, Martincich L, Yeh E, Londero V, Houssami N. Agreement between MRI and pathologic breast tumor size after neoadjuvant chemotherapy, and comparison with alternative tests: individual patient data meta-analysis. BMC Cancer 2015; 15: 662. doi:10.1186/s12885-015-1664-4.

113. Lee SC, Grant E, Sheth P, Garcia AA, Desai B, Ji L, Groshen S, Hwang D, Yamashita M, Hovanessian-Larsen L. Accuracy of Contrast-Enhanced Ultrasound Compared With Magnetic Resonance Imaging in Assessing the Tumor Response After Neoadjuvant Chemotherapy for Breast Cancer. J Ultrasound Med 2017; 36: 901-911. doi:10.7863/ultra.16.05060.

114. Rajan R, Poniecka A, Smith TL, Yang Y, Frye D, Pusztai L, Fiterman DJ, GalGombos E, Whitman G, Rouzier R, Green M, Kuerer H, Buzdar AU, Hortobagyi GN, Symmans WF. Change in tumor cellularity of breast carcinoma after 
neoadjuvant chemotherapy as a variable in the pathologic assessment of response. Cancer 2004; 100:1365-73. doi:10.1002/cncr.20134

115. Abrial SC, Penault-Llorca F, Delva R, Bougnoux P, Leduc B, Mouret-Reynier MA, Mery-Mignard D, Bleuse JP, Dauplat J, Curé H, Chollet P. High prognostic significance of residual disease after neoadjuvant chemotherapy: a retrospective study in 710 patients with operable breast cancer. Breast Cancer Res Treat 2005; 94:255-63. doi:10.1007/s10549-005-9008-8

116. Diaz J, Stead L, Shapiro N, Newell R, Loudig O, Lo Y, Sparano J, Fineberg S. Mitotic counts in breast cancer after neoadjuvant systemic chemotherapy and development of metastatic disease. Breast Cancer Res Treat 2013; 138: 91-7. doi:10.1007/s 10549-013-2411-7

117: Boughey JC, Peintinger F, Meric-Bernstam F, Perry AC, Hunt KK, Babiera GV, Singletary SE, Bedrosian I, Lucci A, Buzdar AU, Pusztai L, Kuerer HM. Impact of preoperative versus postoperative chemotherapy on the extent and number of surgical procedures in patients treated in randomized clinical trials for breast cancer. Ann Surg 2006; 244: 464-70. doi:10.1097/01.sla.0000234897.38950.5c

118. Carey LA, Metzger R, Dees EC, Collichio F, Sartor CI, Ollila DW, Klauber-DeMore N, Halle J, Sawyer L, Moore DT, Graham ML. American Joint Committee on Cancer tumor-node-metastasis stage after neoadjuvant chemotherapy and breast cancer outcome. J Natl Cancer Inst 2005; 97: 1137-42. doi:10.1093/jnci/dji206

119. Neoadjuvant response-guided treatment of HER2 positive breast cancer (PREDIX HER2). ClinicalTrials.gov Identifier: NCT02568839 https://clinicaltrials.gov/ct2/show/NCT02568839?cond=breast+neoadjuvant+tre atment\&rank=31 Accessed 2 August 2018

120. Efficacy and safety of Cabazitaxel versus weekly Paclitaxel as neo-adjuvant treatment in patients with triple negative or luminal B/HER2 normal BC (GENEVIEVE). ClinicalTrials.gov Identifier: NCT01779479 https://clinicaltrials.gov/ct2/show/NCT01779479?cond=breast+neoadjuvant+tre atment\&rank=69 Accessed 2 August 2018 
121. Neoadjuvant Letrozole plus Metformin vs Letrozole plus Placebo for ER-positive postmenopausal breast cancer. ClinicalTrials.gov Identifier: NCT01589367 https://clinicaltrials.gov/ct2/show/NCT01589367?cond=breast+neoadjuvant+tre atment\&rank=97 Accessed 2 August 2018

122. Neoadjuvant Tamoxifen in locally advanced breast cancer in a low/middle income country. ClinicalTrials.gov Identifier: NCT02806544 https://clinicaltrials.gov/ct2/show/NCT02806544?cond=breast+neoadjuvant+tre atment\&draw=2\&rank=101 Accessed 2 August 2018

123. Leary A, Evans A, Johnston SR, A'Hern R, Bliss JM, Sahoo R, Detre S, Haynes BP, Hills M, Harper-Wynne C, Bundred N, Coombes G, Smith I, Dowsett M. Antiproliferative effect of Lapatinib in HER2-positive and HER2-negative/HER3high breast cancer: Results of the presurgical randomized MAPLE trial (CRUKE/06/039). Clin Cancer Res 2015; 21: 2932-40. doi:10.1158/10780432.CCR-14-1428.

124. Honkoop AH, Pinedo HM, De Jong JS, Verheul HM, Linn SC, Hoekman K, Wagstaff J, van Diest PJ. Effects of chemotherapy on pathologic and biologic characteristics of locally advanced breast cancer. Am J Clin Pathol 1997; 107: 211-8.

125. Sharkey FE, Addington SL, Fowler LJ, Page CP, Cruz AB. Effects of preoperative chemotherapy on the morphology of resectable breast carcinoma. Mod Pathol 1996; 9: 893-900.

126. Valent A, Penault-Llorca F, Cayre A, Kroemer G. Change in HER2 (ERBB2) gene status after taxane-based chemotherapy for breast cancer: polyploidization can lead to diagnostic pitfalls with potential impact for clinical management. Cancer Gen 2013; 206: 37-41. doi:10.1016/j.cancergen.2012.12.001

127. Fukada I, Araki K, Kobayashi K, Shibayama T, Takahashi S, Gomi N, Kokubu Y, Oikado K, Horii R, Akiyama F, Iwase T, Ohno S, Hatake K, Sata N, Ito Y. Pattern of tumor shrinkage during neoadjuvant chemotherapy is associated with prognosis in low-grade luminal early breast cancer. Radiology 2018; 286: 49-57. doi:10.1148/radiol.2017161548. 
128. Mocellin S, Goldin E, Marchet A, Nitti D. Sentinel node biopsy performance after neoadjuvant chemotherapy in locally advanced breast cancer: A systematic review and meta-analysis. Int J Cancer 2016; 138: 472-480 doi: 10.1002/ijc.29644

129. Oakes SR, Hilton HN, Ormandy CJ. The alveolar switch: coordinating the proliferative cues and cell fate decisions that drive the formation of lobuloalveoli from ductal epithelium. Breast Cancer Res 2006; 8: 207.

130. Braxton DR, Cohen C, Siddiqui MT. Utility of GATA3 Immunohistochemistry for diagnosis of metastatic breast carcinoma in cytology specimens. Diagn Cytopathol 2015; 43: 271-277. doi: 10.1002/dc.23206

131. Lew M, Pang JC, Jing X, Fields KL, Roh MH. Young Investigator Challenge: The utility of GATA3 immunohistochemistry in the evaluation of metastatic breast carcinomas in malignant effusions. Cancer Cytopathol 2015; 123:576-581. doi: 10.1002/cncy. 21574

132. Rakhshani N, Daryakar A. Are mammaglobin and GCDFP-15 sensitive markers for diagnosis of metastatic basal-like triple negative breast carcinomas? Turk Patoloji Derg 2014; 30:18-22. doi: 10.5146/tjpath.2013.01202

133. Darb-Esfahani S, von Minckwitz G, Denkert C, Ataseven B, Högel B, Mehta K, Kaltenecker G, Rüdiger T, Pfitzner B, Kittel K, Fiedler B, Baumann K, Moll R, Dietel M, Eidtmann H, Thomssen C, Loibl S. Gross cystic disease fluid protein 15 (GCDFP-15) expression in breast cancer subtypes. BMC Cancer 2014; 14: 546. doi: $10.1186 / 1471-2407-14-546$

134. Pala EE, Bayol Ü, Cumurcu S, Keskın E. Immunohistochemical characteristics of triple negative/basal-like breast cancer. Turk Patoloji Derg 2012; 28: 238-244. doi: 10.5146/tjpath.2012.01130

135. Clark BZ, Beriwal S, Dabbs DJ, Bhargava R. Semiquantitative GATA-3 immunoreactivity in breast, bladder, gynecologic tract, and other cytokeratin 7positive carcinomas. Am J Clin Pathol 2014; 142: 64-71. doi: 10.1309/AJCP8H2VBDSCIOBF

136. Gloyeske NC, Woodard AH, Elishaev E, Yu J, Clark BZ, Dabbs DJ, Bhargava R. Immunohistochemical profile of breast cancer with respect to estrogen receptor and 
HER2 status. Appl Immunohistochem Mol Morphol 2015; 23: 202-208. doi: 10.1097/PAI.0000000000000076 


\section{APPENDIX}

\subsection{MAJOR NEW FINDINGS}

To our knowledge, this is the largest series of TNBCs, more specifically CK5 expressing basal like TNBCs assessed with 5 potential IHC markers suggestive of breast origin.

The expression of GATA3, MG, GCDFP-15 and NY-BR-1 is lower in TNBCs than in breast carcinomas in general. With a 5\% staining cut-off more than half of the CK5-positive TNBCs cannot be proven to be of mammary origin.

This is the first study to assess the degree of heterogeneity in regression after PST and look for possible associations with molecular subtypes. Our findings suggest that regression may be inhomogeneous in about half of the cases, and it does not seem to be related to any molecular subtype.

It is suggested that optimally the whole tumor bed should be investigated for the best assessment of regression, and limited sampling by core biopsy might not be suitable in all cases for the evaluation of the presence and degree of regression.

The neoplastic "monster" cells are related to PST including taxanes, and may cause upgrading in tumors with non-high grade nuclei at the start of PST.

Our study of the distribution of lymph node metastases and regression on a limited number of cases do not support a selective regression in SLNs, and therefore this phenomenon cannot explain the somewhat higher false negativity rate of post-PST SLN biopsies.

The structures involved by DCIS that cannot be classified as ducts or acini on the basis of the HE stain and the normal microanatomic distribution do not show an elastic coating characteristic of normal ducts and therefore resemble to acini or are atypical ducts.Structures corresponding to neoducts on the basis of the neoduct score also show a lack of elastic coating and cannot be classified as duct or acini on the basis of microscopic features and distribution. The use of elastic stains may probably be an aid in the study of neoductgenesis. 


\subsection{SUPPLEMENTARY TABLES}

\begin{tabular}{|l|l|}
\hline Histological type & n (\%) \\
\hline No special type (ductal) & $106(92.3 \%)$ \\
\hline Medullary-like & $7(6.1 \%)$ \\
\hline Metaplastic (“matrix producing”) carcinoma & $1(0.8 \%)$ \\
\hline Mixed micropapillary carcinoma & $1(0.8 \%)$ \\
\hline Histological grade & \\
\hline Grade III & $112(97.3 \%)$ \\
\hline Grade II & $3(2.7 \%)$ \\
\hline y)(r)pT category of the tumors & \\
\hline Tx & $1(0.8 \%)$ \\
\hline T0* & $1(0.8 \%)$ \\
\hline T1b or c & $57(49.6 \%)$ \\
\hline T2 & $47(40.9 \%)$ \\
\hline T3 & $3(2.7 \%)$ \\
\hline T4 & $6(5.2 \%)$ \\
\hline Nodal status (y)(r)pN category of the tumors & $\mathbf{3}(2.7 \%)$ \\
\hline Nx & $\mathbf{6 6}(57.4 \%)$ \\
\hline No** & $9(7.8 \%)$ \\
\hline N1*** & \\
\hline N2 & \\
\hline N3 & \\
\hline & \\
\hline
\end{tabular}

Supplementary table 1. Basic pathologic features of the tumors selected for TMA. (y)(r)pT and $(\mathrm{y})(\mathrm{r}) \mathrm{pN}$ categories refer to the TNM classification based $\mathrm{pT}$ and $\mathrm{pN}$ categories of primary tumors $(\mathrm{n}=$ 101) together with those of recurrent tumors $(r, n=4)$ and tumors after primary (i.e. neoadjuvant) systemic treatment $(\mathrm{y}, \mathrm{n}=10)$. $*$ One case with intramammary nodal recurrence; ** including 4 patients with isolated tumor cells; $* * *$ including 10 cases with micrometastasis. 


\begin{tabular}{|c|c|}
\hline Clinical parameters & \\
\hline \multicolumn{2}{|l|}{ Age (year) } \\
\hline Range & $32-77$ \\
\hline mean / median & $54.5 / 55$ \\
\hline \multicolumn{2}{|l|}{ Type of surgery $(\mathrm{n} ;(\%))$} \\
\hline Mastectomy & $71(66.9)$ \\
\hline Breast conserving surgery & $35(33.1)$ \\
\hline \multicolumn{2}{|l|}{ Type of lymphadenectomy $(\mathrm{n} ;(\%))$} \\
\hline $\begin{aligned} \text { SLNB } \\
\end{aligned}$ & $35(33.1)$ \\
\hline ALND & $80(75.4)$ \\
\hline SLNB+ALND & $10(9.4)$ \\
\hline None & $1(0.9)$ \\
\hline \multicolumn{2}{|l|}{ Histological type of tumor $(\mathrm{n} ;(\%))$} \\
\hline NST & $100(94.5)$ \\
\hline Lobular & $4(3.7)$ \\
\hline Other & $2(1.8)$ \\
\hline \multicolumn{2}{|l|}{ ypT (n; (\%)) } \\
\hline урТ0 & $25(23.6)$ \\
\hline ypTis & $5(4.7)$ \\
\hline урT1a & $8(7.5)$ \\
\hline урT1b & $9(8.6)$ \\
\hline урT1с & $18(16.9)$ \\
\hline урТ2 & $30(28.3)$ \\
\hline урT3 & $9(8.6)$ \\
\hline урT4 & $2(1.8)$ \\
\hline \multicolumn{2}{|l|}{ ypN (n; (\%)) } \\
\hline ypNo & $55(51.8)$ \\
\hline ypN1 & $26(24.5)$ \\
\hline ypN2 & $12(11.3)$ \\
\hline ypN3 & $11(10.3)$ \\
\hline no data & $2(1.8)$ \\
\hline \multicolumn{2}{|l|}{ Grade on core needle biopsy (n; (\%)) } \\
\hline $\begin{array}{r}1 \\
\end{array}$ & $6(5.6)$ \\
\hline 2 & $41(38.7)$ \\
\hline 3 & $59(55.7)$ \\
\hline \multicolumn{2}{|l|}{ Treatment (n; (\%)) } \\
\hline anthracycline $+/$ - targeted therapy & $9(8.6)$ \\
\hline taxane $+/$ - platinum derivatives & $27(25.4)$ \\
\hline anthracycline + taxane & $70(66.0)$ \\
\hline
\end{tabular}

Supplementary table 2. Clinical characteristics of patients. (SLNB: sentinel lymph node biopsy, ALND: axillary lymph node dissection, NST: breast carcinoma of no special type, ypT and ypN: categories defined by the $8^{\text {th }}$ edition of the Cancer staging manual introduced by the AJCC [6:AJCC]) 


\begin{tabular}{|c|c|}
\hline \multicolumn{2}{|l|}{ Specimen } \\
\hline Mastectomy & $9(42.8 \%)$ \\
\hline Breast conserving surgery & $12(57.2 \%)$ \\
\hline \multicolumn{2}{|l|}{ Histological diagnosis } \\
\hline Pure DCIS & $9(42.8 \%)$ \\
\hline DCIS with invasive carcinoma & $12(57.2 \%)$ \\
\hline \multicolumn{2}{|l|}{ Estrogen receptor } \\
\hline positive & $13(61.9 \%)$ \\
\hline negative & $8(38.1 \%)$ \\
\hline \multicolumn{2}{|l|}{ Progesterone receptor } \\
\hline positive & $11(52.3 \%)$ \\
\hline negative & $10(47.7 \%)$ \\
\hline \multicolumn{2}{|l|}{ HER-2 } \\
\hline $3+$ & $11(52.3 \%)$ \\
\hline $2+$ & $1(4.8 \%)$ \\
\hline $1+$ & $1(4.8 \%)$ \\
\hline negative & $8(38.1 \%)$ \\
\hline \multicolumn{2}{|l|}{ Molecular subtype } \\
\hline Luminal A or B & $13(61.9 \%)$ \\
\hline HER-2 & $7(33.3 \%)$ \\
\hline TNBC & $1(4.8 \%)$ \\
\hline
\end{tabular}

Supplementary table 3. Basic clinicopathological information of the cases studied (DCIS: ductal carcinoma in situ, HER-2: human epidermal growth factor receptor-2; TNBC: triple negative breast cancer) 


\begin{tabular}{|c|c|c|c|c|c|c|}
\hline Author (year) & cut off & Tumor type & GATA-3 & MG & GCDFP-15 & NY-BR-1 \\
\hline Ordonez et al. [17] & any staining & metastatic TNBC & $12 / 40(30 \%)$ & $7 / 40(17.5 \%)$ & $6 / 40(15 \%)$ & -- \\
\hline \multirow[t]{2}{*}{ Krings et al. [108] } & any staining & primary TNBC & $72 / 109(66 \%)$ & $28 / 107(26.1 \%)$ & $17 / 109(15.5 \%)$ & -- \\
\hline & & & & & & -1 \\
\hline Braxton et al. [130] & $>10 \%$ & metastatic TNBC & $30 / 35(85.7 \%)$ & $9 / 35(25.7 \%)$ & $5 / 35(14.2 \%)$ & -- \\
\hline \multirow[t]{2}{*}{ Cimino-Matthews et al. [25] } & $>5 \%$ & primary TNBC & $19 / 44(43.1 \%)$ & -- & -- & -- \\
\hline & & metastatic TNBC & $5 / 9(55.5 \%)$ & -- & -- & -- \\
\hline Lew et al. [131] & any staining & metastatic TNBC & $11 / 13(84.6 \%)$ & $4 / 13(30.7 \%)$ & $1 / 13(7.6 \%)$ & -- \\
\hline \multirow[t]{2}{*}{ Huo et al. [12] } & $\begin{array}{l}\text { any staining } \\
>5 \%\end{array}$ & primary TNBC & \begin{tabular}{|l|}
$25 / 62(40.3 \%)$ \\
$14 / 62(22.58 \%)$
\end{tabular} & $\begin{array}{l}16 / 62(25.8 \%) \\
7 / 62(11.2 \%)\end{array}$ & \begin{tabular}{|l|}
$9 / 62(14.5 \%)$ \\
$4 / 62(6.4 \%)$
\end{tabular} & - \\
\hline & $\begin{array}{l}\text { any staining } \\
>5 \%\end{array}$ & metastatic TNBC & $\begin{array}{l}30 / 68(44.1 \%) \\
18 / 68(26.4 \%)\end{array}$ & $\begin{array}{l}22 / 68(32.3 \%) \\
10 / 68(14.7 \%)\end{array}$ & $\begin{array}{l}11 / 68(16.1 \%) \\
6 / 68(8.8 \%)\end{array}$ & -- \\
\hline Lewis et al. [38] & any staining & $\begin{array}{l}\text { primary basal- } \\
\text { like TNBC }\end{array}$ & - & $5 / 24(20.8 \%)$ & $1 / 5(20 \%)$ & - \\
\hline Rakhshani et al. [132] & $>10 \%$ & $\begin{array}{l}\text { primary basal- } \\
\text { like TNBC }\end{array}$ & -- & $6 / 66(9 \%)$ & $12 / 66(18.1 \%)$ & -- \\
\hline Darb-Esfahani et al. [133] & any staining & primary TNBC & -- & -- & $34 / 130(26.1 \%)$ & -- \\
\hline Pala et al. [134] & $>5 \%$ & primary TNBC & -- & -- & $8 / 41(19.5 \%)$ & -- \\
\hline Deftereos et al. [13] & H-score 99.4 & primary TNBC & $7 / 28(25 \%)$ & $2 / 28(7.1 \%)$ & $5 / 28(17.8 \%)$ & -- \\
\hline Clark et al. [135] & at least $4 \%$ & primary TNBC & $22 / 30(73.3 \%)$ & -- & -- & -- \\
\hline Gloyeske et al. [136] & $\begin{array}{l}\text { any staining } \\
>10 \mathrm{H} \text {-score }\end{array}$ & primary TNBC & $22 / 30(73 \%)$ & $6 / 31(19 \%)$ & $5 / 32(16 \%)$ & $5 / 30(17 \%)$ \\
\hline Our work & $\begin{array}{l}\text { any staining } \\
>5 \%\end{array}$ & $\begin{array}{l}\text { primary (or } \\
\text { recurrent) TNBC }\end{array}$ & $\begin{array}{l}82 / 115(71.3 \%) \\
23 / 115(20.0 \%)\end{array}$ & $\begin{array}{l}30 / 115(26.0 \%) \\
12 / 115(10.4 \%)\end{array}$ & $\begin{array}{l}23 / 115(20.0 \%) \\
9 / 115(7.8 \%)\end{array}$ & $\begin{array}{l}7 / 115(6.0 \%) \\
3 / 115(2.6 \%)\end{array}$ \\
\hline Sensitivity; 95\% CI* & & & $43.7 \% ; 0.397-0.477$ & $16.3 \% ; 0.135-0.195$ & $15,1 \% ; 0,127-0,179$ & $5.5 \% ; 0.028-0.105$ \\
\hline
\end{tabular}

Supplementary table 4. Summary of results from other series exploring the labeling of TNBCs.* For calculating sensitivity values, all publications with data were considered, and whenever there were data with two staining cut-offs, the $>5 \%$ data were included only 


\subsection{MAGYAR NYELVÜ ÖSSZEFOGLALÓ}

Az emlörák a leggyakoribb rosszindulatú daganat az európai nők körében. A szervezett emlörák szürések, a média reflektorfénye, a számos magas színvonalú tudományos konferencia felhívja a figyelmet a betegség epidemiológiai, szociológiai és pszichológiai fontosságára. A tézis írásakor a PubMed adatbázis a "breast cancer" szavak alapján végzett kutatás során 369900 különböző tudományos dolgozatot ajánlott fel. A tudományos publikációk óriási száma az emlőrákkutatás iránti nagy érdeklődésre világít rá. Munkánkban a tripla negatív emlőrákok (TNBC) immunfenotípizálására (1), a primer szisztémás kezelés (PST) tumor ágyra (2) és az axilláris nyirokcsomókra kifejtett hatásaira (3), valamint a potenciális neoductgenesis eseteire, azaz a comedo-szerü necrosist és amorf kalcifikációt mutató diffúz in situ ductalis carcinomára (DCIS) fókuszáltunk (4).

A TNBC-ket az ER, PR és HER2 immunhisztokémiai negativitásuk alapján definiáljuk. Habár az emlőbe adott áttétek ritkák, a TNBC egyéb szervekbe adott távoli áttéteivel gyakran találkozunk. Egy TNBC áttét emlő eredetének megerősítése diagnosztikus kihívás, mivel a gyakran használt, ám az emlő eredetére nézve korán sem specifikus ER definíció szerint negatív ezen daganatokban. Jelen vizsgálatunkban a GATA3, a MG, a GCDFP-15 és az NYBR-1 immunhisztokémiai (IHC) markerek expresszióját vizsgáltuk, melyek - legalábbis az adatlapjuk leírása szerint - emlő eredetet támogatnak. Az IHC vizsgálatainkat tissue microarray technikával CK5 expressziót mutató, tehát bazális szerü TNBC-ken végeztük. Eredményeink alapján az emlő eredetet támogató IHC markerek szenzitivitása a következő: GATA-3: 43,5\% (95\%CI 39,6-47,6\%), MG: 16,4\% (95\%CI: 13,6-19,6\%), GCDFP-15: 15,1\% (95\%CI: 12,7-17,9\%) és NY-BR-1: 5,4\% (95\%CI: 2,7-10,3\%).

Tudomásunk szerint közleményünk, a legnagyobb elemszámú olyan dolgozat, melyben e négy emlő eredetet támogató IHC marker expresszióját vizsgálták TNBC-k eseteiben, sőt a munkánkban a TNBC-k egy speciális szubtípusára, a CK5-öt expresszáló bazális szerü emlörákokra fókuszáltunk. A GATA3, a MG, a GCDFP-15 és a NY-BR-1 expressziója alacsonyabb TNBC-kben, mint általában az emlőrákokban. Habár ezen markerek más tumorokban is pozitívak lehetnek, használatukkal a bazális szerủ emlőrákok egy részénél az emlő eredet alátámasztható. Noha a pozitív festődés emlő eredetet támogat, a negativitás sem zárja ki egyértelmüen ennek ellentétét. Úgy gondoljuk, hogy metasztatikus tumorok esetén a 
GATA-3, a MG és a GCDFP-15, mint IHC panel használata segíthet az emlő eredet megerősítésében, ha az ER és PR negatív.

A PST vizsgálatok végpontjainak meghatározásában a patológiai észlelés döntő szerepet játszik. A PST-t követő szövettani eltérések összetettek, ezért a minták szisztematikus vizsgálata elengedhetetlen a pontos diagnózis és a legmegfelelőbb kezelés meghatározásához. A minták kezelésének és kórszövettani interpretációjának standardizálása kiemelten fontos a PST vizsgálatok egyik indikátorának, a komplett patológiai regressziónak (pCR) és a reziduális betegségnek a detektálásában.

Habár a cellularitás változása a PST egyik legjellemzőbb hatása, vizsgálata mégsem része a rutin szövettani leletezésnek. Jelen munkánkban a PST előtti biopsziákon és posztoperatív mintákon vizsgáltuk a cellularitás változását. Az esetek döntő többségében a cellularitás csökkent és szignifikáns korrelációt észleltünk a cellularitás- és a méretváltozás között.

Eredményeink alapján a regresszió homogenitása és inhomogenitása nem függ a molekuláris szubtípustól: megközelítőleg az esetek fele homogén, fele inhomogén regressziót mutat. Az inhomogén regresszió többsége minor inhomogenitásnak bizonyult, mely közepes vagy kis nagyítású látótérben látszott. A „scatter pattern”, illetve a „concentric shrinkage” kivételesen ritka volt. Habár a diagnosztikus diszkrepanciákat okozó „scatter pattern”, melynél egész metszeteken lehet komplett regresszió a máshol megmaradt reziduális daganat mellett, a legproblematikus mintázat, a minor heterogenitás is vezethet téves interpretációhoz, amennyiben csak „core” biopsziákkal vizsgálják a regressziót PST után.

Számos befejezett és jelenleg is folyó vizsgálat ismert, melyeknél az időközi, vagy végleges „core” biopsziás mintavétel a protokoll része. Ezen vizsgálatokra kiemelkedő hatással lehet a - különösen a „scatter pattern” esetében fellépő - tumorregressziónak vagy a regresszió hiányának a heterogenitása. Az inhomogén regressziót mutató esetekben végzett limitált, időközi és/vagy PST utáni „core” biopsziás mintavétel diszkrepanciák forrása lehet, amennyiben a mintát a tumorágy azon részéből vették, ahol komplett regresszió vagy épp a regressziós jelek teljes hiánya mutatkozik. Ezen diagnosztikus hibák elkerülése érdekében több szövethengert eredményező „core” biopsziás mintavételre van szükség, amennyiben a teljes tumorágy vizsgálata nem lehetséges. 
A “monster" sejteknek elnevezett, nagyméretü, több és/vagy nagy magvú neoplasztikus sejtek jelenlétét többnyire a PST hatásának tulajdonítják. Ezen sejtek csaknem kizárólag taxán tartalmú kezelés mellett jelentkeztek. A taxán fő hatása a mikrotubulus funkció inhibíciója, ami a mitotikus orsó kialakulását gátolja. Eredményeink alapján a “monster” sejtek jelenléte növelheti a nukleáris atípiát és ezen keresztül PST-t követően “upgrading” valósulhat meg. A poliploidizáció miatt ezen sejtekben számos gén kópiaszáma megnövekedhet, akár a HER2-é is, aminek bizonytalanok a terápiás konzekvenciái.

Tudomásunk szerint munkánk az első dolgozat, amelyben a regresszió heterogenitásának molekuláris szubtípusokkal való összefüggéseit vizsgálták. Eredményeink alapján az esetek közel felében a regresszió inhomogén, és nem mutat összefüggést a molekuláris szubtípusokkal. A teljes tumorágy vizsgálata szükséges a regresszió megítéléséhez. A PST hatásának tulajdonított "monster" sejtek a taxán kezelés hatására alakulnak ki és “upgrading”-hez vezethetnek a PST előtt alacsony vagy közepes nukleáris atípiát mutató eseteknél.

Mivel a szentinel nyirokcsomó (SLN), a tumor testhez legközelebb helyezkedik el, ezért leggyakrabban az első nyirokcsomó, amely a daganat nyirokúton történő terjedése során érintetté válhat. Általában ezt követően alakul ki a nem szentinel nyirokcsomókban (nonSNL) az áttétes betegség. A morfológiai és funkcionális eltéréseket magában foglaló tumor reaktív lymphadenopátia (TRL) egy komplex nyirokcsomó reakció, amely még a metasztatikus tumorsejtek érkezése előtt elkezdődik. A morfológiai változásokat illetően, korábbi tanulmányok a tumort drenáló nyirokcsomók megnagyobbodását, a vér- és nyirokerek számának növekedését és strukturális remodellációját, valamint a magas endotélü venulák endotélsejtes proliferációját írták le. A funkcionális eltérések közül a megnövekedett vér perfúziót, a megváltozott immunológiai státuszt, azon belül a CD4 és CD8 pozitív T-

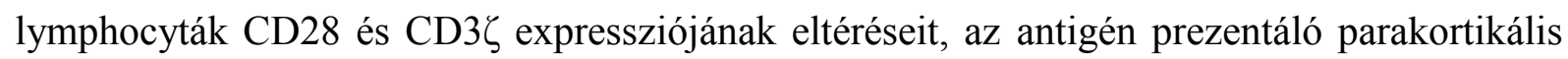
dendritikus sejtek dendritikus denzitásának, valamint komplexitásának csökkenését emelték ki.

A fent leírt tényezők a PST után teoretikusan megváltoztathatják a szentinel nyirokcsomóban észlelt reakciókat a tumorral nem közvetlenül kapcsolódó, nem szentinel nyirokcsomókhoz képest. A TRL által érintett nyirokcsomókban a megnövekedett perfúzió és a sürübb érhálózat megnövelheti a kemoterápiás szerek, valamint a célzott terápiás 
gyógyszerek (pl.: hormon receptor modulátorok vagy trastuzumab) hatását. A szentinel nyirokcsomókban megvalósuló kifejezettebb regresszió akár komplett regresszióhoz is vezethet az SLN-ben, miközben tumorosan érintett nyirokcsomók (non-SLN) maradhatnak hátra. Mindez befolyásolhatja az SLN biopszia esetén észlelt álnegatív esetek arányát is. Egy másik lehetőség szerint az SLN-ekben immunszuprimált állapot alakul ki a non-SLN-ekhez képest, ami a cytotoxikus szerek hatását csökkentheti. A szelektív regresszió, vagy épp ennek ellentéte befolyásolhatja a jelölt, a PST elött pozitívnak bizonyult nyirokcsomó eltávolításának a stádium meghatározásban betöltött szerepét.

Limitált esetszámú eredményeink alapján az esetek eloszlása nem támogatta, de nem is szólt az SLN-ekben kialakuló szelektív regresszió ellen. A nyirokcsomókban kialakuló fibrotikus gócokat általában a regresszió jelének tulajdonítottuk, noha ezen eltérések nem specifikusak és más folyamat is eredményezhette őket. PST esetén ezen gócok kialakulásának legvalószínűbb oka maga a kezelés, ezért ezeket egyöntetűen regressziós jelnek definiáltuk. Az SLN-ekben elméletileg egy időben alakul ki immunszupresszió, illetve TRL. Adataink alapján a regresszió fokát illetően nincs szignifikáns különbség az SLN-ek és a non-SLN-ek között, amely az SLN-ekben megvalósuló szelektív regressziót támogatná. Ezért ezen jelenség nem magyarázza, hogy miért magasabb az álnegatív esetek aránya a PST utáni SLN biopsziák során.

Az emlő parenchymát felépítő lobuláris szerveződés hasonló egy fához, melyben a ductus lactiferus alkotja a fa törzsét, a ductusok a fa ágait, a lobulusok pedig a fa leveleit. A lobulusok acinusait és a ductusokat egyszerü elkülöníteni egymástól. Míg mind a ductusoknak, mind a lobulusoknak közös jellemzője a külső myoepithel sejtréteg és a basalis membrán, addig az elasztikus rostréteg csak a ductusok körül észlelhető. Amikor DCIS alakul ki a ductalis fában és a végeit képző terminális ductulobularis egységben, ezen normális anatómiai struktúrák gyakran kitágulnak, de architektúrájuk megmarad, ezzel szemben a nagy ductusokat is érintő (diffúz), comedo-szerü nekrózissal kísért DCIS nem követi a fent leírt növekedési mintázatot, hanem a normálisnál sürübb eloszlású, többnyire monomorf és tágult lumenü képlet képződik. A neoductgenesis teóriája ezen utóbbi emlőrákok morfológiájára próbál magyarázatot adni, melyben a neoplasztikus sejtek egymás melletti, szorosan elhelyezkedő struktúrákat alkotnak olyan módon, hogy már meglevő ductalis struktúrákból “pushing” típusú infiltrációs széllel növekszenek ki és képeznek új ductusokat, "neoduct”- 
okat. Ez magyarázhatja ezen esetek rosszabb kimenetelét azokhoz az emlörákokhoz viszonyítva, ahol nincs diffúz DCIS.

Eredményeink alapján a comedo-szerü nekrózist mutató DCIS-sel érintett, nagy denzitású struktúrákat nem lehet a HE metszeten észlelt megjelenés alapján ductusnak vagy acinusnak nevezni. A munkánk során a változó bizonyossági fok alapján ductusnak vagy acinusnak besorolt struktúrák körül a normális anatómiai struktúrák alapján várt elasztikus rostokat tudtunk kimutatni. Másrészt a legtöbb, sem ductusnak sem acinusnak nem identifikálható struktúra, illetve a minden egyes elemre alkalmazott „,neoductgenesis score” által „neoduct”-nak tartott struktúra körül hiányoztak az elasztikus rostok. Habár ezen tények a struktúrák acinus eredete mellett is szólhatnának, valószínübb, hogy a korábban leírt periductalis tenascin-C akkumuláció mellett ez egy újabb különbség a már meglévő és az új eredetű ductusok között. Korábbi tanulmányokban már bemutatták, hogy a myoepithel sejtek myoepithel immunomarker expressziója egyes DCIS-t tartalmazó emlőrákokban megváltozik: egy vagy több myoepithel marker festődése elvész. Noha a myoepithel markereket nem vizsgáltuk jelen munkánkban, az elasztikus rostok eltűnését, mint egy további eltérést észleltük comedo-szerü necrosist mutató DCIS eseteiben.

Ezen képletek a bazális membrán és a myoepithel sejtek jelenléte alapján megfelelhetnek egyrészt már meglévő ductusoknak és acinusoknak, bár a normális emlőre jellemző fatörzs-faág architektúra egyáltalán nem észlelhető. Ezen esetek további háromdimenziós vizsgálatáról szóló tanulmányok arra utaltak, hogy a ductusok és acinusok normális eloszlása hiányos. A zavart "arborizáció" hátterében a hibás alveoláris "switch" állhat, ami egy hormonok által vezérelt, fiziológiás folyamat, melynek során acinusok fejlődnek ki a ductushámból. Saját eredményeink alapján a neoductnak vélt struktúrák esetében hiányzik az elasztikus rostköpeny, mely alapján az acinusokra hasonlítanak ebből a szempontból.

Több képletet észleltünk, melyeket egyértelműen nem tudtunk ductusnak vagy acinusnak besorolni, mint amennyi struktúra "neoduct"-nak felelt meg az egyes struktúrákra vonatkoztatott „,neoductgenesis score” alapján. Ezen osztályozhatatlan struktúrák általában nem rendelkeznek elasztikus rostokkal. Eredményeink alapján úgy gondoljuk, hogy azok a potenciális "neoduct"-ok, amelyek nem rendelkeznek elasztikus rostokkal és nem sorolhatók be egyértelműen a ductusok és az acinusok közé az architekturális mintázat alapján. Az elasztikus rostok vizsgálata segítséget nyújthat a neoductgenesis vizsgálatában. 
I. Zombori T, Cserni G. Immunohistochemical analysis of the expression of breast markers in basal-like breast carcinomas defined as triple negative cancers expressing keratin 5. Pathol Oncol Res. 2018;24:259-267. doi: 10.1007/s12253-017-0246-y.

IF: 1.93 


\title{
Immunohistochemical Analysis of the Expression of Breast Markers in Basal-like Breast Carcinomas Defined as Triple Negative Cancers Expressing Keratin 5
}

\author{
Tamás Zombori ${ }^{1}$ (D) Gábor Cserni ${ }^{1,2}$
}

Received: 7 January 2017 / Accepted: 27 April 2017 /Published online: 3 May 2017

(C) Arányi Lajos Foundation 2017

\begin{abstract}
Estrogen and progesterone receptors are possible markers for suggesting a mammary origin of metastatic carcinoma, but are useless in cases of triple negative breast cancers (TNBC). Five other potential markers of breast origin were investigated on tissue microarrays in a series of TNBCs showing keratin 5 expression, consistent with a basal-like phenotype. GATA-3 staining was observed in 82 of 115 triple negative cases $(71.3 \%)$ including 23 cases with $>5 \%$ staining. Mammaglobin staining was detected in 30 cases $(26.0 \%)$ including 12 with $>5 \%$ staining. GCDFP-15 was seen in 23 cases $(20.0 \%)$ including 9 with $>5 \%$ staining. NY-BR-1 positivity was present in 7 cases $(6.0 \%)$ including 3 patients with $>5 \%$ staining. BCA-225 staining was observed in 74 cases (64.3\%); however this latter marker lacks also specificity owing to the reported widespread staining in other malignancies. GATA-3, mammaglobin and GCDFP-15 coexpression was seen in one case $(0.9 \%)$, whereas GATA-3 and mammaglobin or mammaglobin and GCDFP-15 coexpression was present in 2 and 2 cases (1.7\%), respectively. Using at least 5\% staining as cut-off, the expression of any of the last 4 markers was $34.7 \%$. The expression of GATA-3, mammaglobin, GCDFP15 and NY-BR-1 is lower in TNBC-s than in breast carcinomas in general, and this may be even lower in basal-like carcinomas. Although these markers are not fully specific, by using them, a subset of basal-like TNBC-s can be identified
\end{abstract}

Tamás Zombori

zomtam@gmail.com

1 Department of Pathology, University of Szeged, Faculty of Medicine, Állomás u. 1, Szeged 6725, Hungary

2 Department of Pathology, Bács-Kiskun County Teaching Hospital, Kecskemét, Hungary as of mammary origin. However, a substantial proportion will not show any staining with any of these markers.

Keywords Basal-like · Triple negative breast cancer . GATA-3 · Mammaglobin · GCDFP-15 · NY-BR-1

\section{Background}

Breast cancer remains the most frequent malignant tumor among women in Europe [1,2]. Although it is often mentioned as a single disease in such statistics, it is obvious that the term refers to several different diseases.

Perou and coworkers evaluated gene expression in breast cancer samples and suggested a molecular classification of the disease [3]. In their original classification, basal-like, Erb-B2 (human epidermal growth factor receptor 2) overexpressing (HER2+), normal-breast-like and luminal (estrogen receptor positive, ER+) breast cancers had been identified. Gene expression profiling is the gold standard for the identification of these molecular breast cancer subtypes, but this method is not widely available. To make the classification more affordable to most pathology laboratories, immunohistochemical (IHC) profiles have been correlated to the molecular profiles. According to the IHC surrogate classification, breast carcinomas can be classified into luminal A-like (ER+ and/or progesterone receptor (PR) + and HER2- with low proliferation), luminal B-like (ER+ and/or PR+ and HER2+ and/or highly proliferating on the basis of $\mathrm{Ki}-67$ labeling), HER2+ nonluminal-like (ER-, PR- and HER2+) and triple-negative breast cancer (TNBC; ER-, PR- and HER2-). The latter group can be subclassified into basal-like TNBC (keratin (CK) 5/6+ and/or epidermal growth factor receptor, EGFR+) and non-basal-like TNBC (CK 5/6- and EGFR-) [4]. 
Metastases of breast cancer develop through either the lymphatic or the blood vessels, and affect regional lymph nodes and distant organs, including the lungs, the liver, bones, and the brain. Since the lifetime risk of developing cancer is about one out of three women [5], second primaries are not rare, and must be separated from metastases of a known breast cancer. Sometimes, metastasis is the first clinical sign of an unknown primary breast cancer. In case of metastatic carcinoma, it is essential to prove its metastatic nature and origin.

Despite their less than perfect specificity, ER, PR and HER2 are among the most useful IHC markers for suggesting breast origin. These antibodies can be helpful in cases of luminal A-like, luminal B-like and HER2+ subtypes, but not in cases of TNBC which represent approximately $15 \%$ of all breast cancers [6]. Without the information of a previous primary breast carcinoma, and because of its phenotypic overlap with other potential primaries, a triple negative case can easily confuse the pathologist. Several immunomarkers as GATA-3, mammaglobin, gross cystic disease fluid protein-15 (GCDFP15 ) and NY-BR-1 have been studied recently to verify the breast origin in metastatic cancer.

GATA-3 is a transcription factor with role in cell proliferation and differentiation of breast luminal epithelial cells. GATA3 is involved in T-cell-specific cell regulation, in the development of the skin and its adnexal structures and in carcinomas [7, 8]. Previously, GATA-3 was thought as specific marker of breast and urothelial origin, but recent studies have shown its presence in squamous carcinoma of the skin, lung, uterine cervix, vulva, larynx and anus, salivary gland tumors, basal cell carcinoma, apocrine carcinoma, skin adnexal tumors, Brenner tumor, mesothelioma, chromophobe renal cell carcinoma, pancreatic adenocarcinoma, germ cell tumors and paraganglioma [9-12]. GATA3 and ER are closely associated and involved in a positive cross-regulatory loop. This explains the positive correlation between GATA3 and ER expression in breast cancers [13,14]. Although some studies have suggested a prognostic or predictive role for GATA3 expression [15-18], it can also be viewed as a marker to prove the mammary origin of metastatic cancer. The expression frequency of GATA-3 ranges from $47 \%$ to $100 \%$ among all breast adenocarcinomas [10,11, 13, 19-22].

Mammaglobin A (MG) was described by Watson et al. in 1997 as a $10.5 \mathrm{kD}$ secretory protein that shares homology with the uteroglobin family [23]. The gene of MG is located at $11 \mathrm{q} 13$, which is frequently amplified in breast carcinoma [24]. MG is generally positive in normal breast epithelium. Besides breast carcinomas, several tumors express MG, like endometrial carcinoma, sweat gland tumors, gastric, pulmonary, colonic and ovarian tumors and some melanomas [25-30]. The overall expression rate among all breast carcinomas is approximately $80 \%[23,25,26,28,31-33]$.

Gross cystic disease fluid protein-15 (GCDFP-15 or BRST2) was detected in breast gross cystic disease fluid by
Haagensen et al. in 1977. The monomer of GCDFP-15 has a molecular weight of $15 \mathrm{kD}$ [34]. Its gene region was found on chromosome 7. GCDFP-15 is normally present in apocrine metaplasia of the breast and its presence has been described in salivary and sweat gland tumors and prostatic carcinomas [35]. The reported expression frequency of GCDFP-15 ranges from $25 \%$ to $85 \%$ among all breast adenocarcinomas $[25,26$, $32,33,35,36]$.

NY-BR-1, a differentiation antigen of the mammary tissue was first described by Jäger et al. in 2001 [37]. Bioinformatic analysis has revealed that NY-BR1 has a DNA-binding site followed by a leucine zipper motif, therefore it could be a transcription factor. Due to its five ankyrin tandem repeats, it may have a role in protein-protein interactions, as well [37]. It has been detected in the epithelial cells of mammary ducts and lobules and in normal testis. One third of sweat gland tumors [38] showed positivity with NY-BR1. Although NY-BR-1 positivity was demonstrated in a case of vulvar phyllodes tumor [39], there is no other normal or tumor tissue which has been reported to express this protein, therefore NY-BR-1 appears to be a breast-specific protein. In invasive breast carcinomas, the range of NY-BR-1 expression has been reported between $46.6 \%$ and $70 \%$, showing a strong association with ER and lower-grade carcinomas [38, 40-45].

BCA-225 is a glycoprotein with a molecular weight between $225.000-250.000 \mathrm{kD}$. It was first identified by MesaTejada and coworkers in 1988 [46]. Although it was previously described as a specific immunomarker of breast carcinoma, a later study by Loy and associates concluded that BCA-225 is commonly expressed in human adenocarcinomas of different origins, and is therefore not specific for the breast [47]. BCA225 expression was often present in adenocarcinomas of the breast (98\%), kidney (94\%), ovary (80\%), lung (74\%) and intermediate expression rates $(36 \%-68 \%)$ were found in adenocarcinomas of the prostate, bile ducts, thyroid, endometrium, endocervix and pancreas [47].

Although the mentioned "breast markers" have been tested in several series of breast carcinomas, only a few cases of TNBC have been assessed for them. TNBC also constitute a heterogeneous group of breast carcinomas, and basal-like carcinomas have not been specifically investigated for the expression of the above markers. The aim of the present study was to look at the IHC staining of GATA-3, MG, GCDFP-15, NY-BR-1 and BCA-225 in a series of TNBCs showing CK5 expression, and therefore being consistent with a basal-like phenotype on the basis of the IHC-based surrogate molecular classification.

\section{Materials and Methods}

Invasive breast carcinomas operated on at the Bács-Kiskun County Teaching Hospital, Kecskemét between August 
2005 and August 2015 and fulfilling the criteria of TNBC and CK5 positivity by IHC were selected for tissue microarray (TMA) construction. All of the specimens were fixed in $10 \%$ neutral buffered formalin for at least $24 \mathrm{~h}$. Only cases with more than 3 paraffin blocks available were used; otherwise the cases represent a consecutive series of such tumors. ER, PR and HER-2 IHC results were obtained from the histopathology reports.

The TMAs were constructed from archived paraffinembedded blocks using a TMA builder device (Histopathology Ltd., Pécs, Hungary). Each TMA contained 20 tumor tissue cores, $2 \mathrm{~mm}$ in diameter. These were arranged in 5 rows and 4 columns and an additional row contained 2 non-mammary control tissues for orientation and identification purposes. Each carcinoma was represented in duplicate in 2 different TMAs, and the areas sampled were preferentially from the edge of the tumors. Care was taken to include minor amounts of normal paratumoral breast tissue in each TMA to serve as internal controls for the IHC reactions.

IHC for GATA-3, MG, GCDFP-15, NY-BR-1 and BCA225 was performed using the antibodies and details listed in Table 1. All antibodies were used on both sets of TMAs, (i.e. two 2-mm-diameter cores of each tumor), except for BCA225 , where only one set of cores (and TMAs) was immunostained. The stains were assessed by the two authors by evaluating the proportion of nuclear (GATA-3) and cytoplasmic (MG, GCDFP-15 and BCA-225) or both nuclear and cytoplasmic (NY-BR-1) labeling of tumor cells. A staining of $5 \%$ or more cells was considered a positive result.

The institutional ethical committee of the Bács-Kiskun County Teaching Hospital was consulted and approved this non-interventional retrospective study. The institutional data safety manager also gave approval for this study not requiring patients' identity related data.

\section{Results}

All markers could be evaluated in only 115 of the 118 tumors sampled, therefore the result are reported for these 115 cases. In 3 cases, the tissue cores were not evaluable due to necrosis or lack of tumor cells. The series included 4 recurrent tumors (including 1 with intramammary nodal recurrence only) and
10 cases treated with neoadjuvant systemic therapy with no or minimal $(0-10 \%)$ regression. The basic characteristics of these tumors are summarized in Table 2 .

GATA-3 labelling was characterized by intense nuclear staining in the tumor cells. In a few specimens, weak nuclear staining was noted in a very small minority of lymphocytes, but this could not be confounded with either tumor cell positivity or the staining of normal mammary epithelium. MG, GCDFP-15, NY-BR-1 and BCA-225 positivity was identified as obvious cytoplasmatic staining. Although the data sheet of NY-BR-1 suggests that occasional nuclear staining may occur with this antibody, this was not noted in tumor cells, but was present in a few normal breast epithelial cells. Examples of diffuse and focal IHC staining are presented in Fig. 1, to demonstrate the range of positive reactions seen in the tumor samples.

The IHC results are displayed in Tables 3 and 4, which show both the proportion of tumors demonstrating any degree of staining with a given marker and the proportion considered positive according to the $5 \%$ cut-off used in this study. Taking any staining into account, GATA3 and BCA-225 labeling was seen in the majority of the cases, followed by MG and GCDFP-15, whereas NY-BR-1 immunoreactivity was seen in only a few tumor samples. Using the 5\% cut-off, there was a marked drop in the proportion of cases showing GATA3 positivity, but reductions were seen with all markers. Only one third of the cases showed notable (at least 5\%) staining with any of the 4 markers considered to be more specific for a breast origin if a few caveats are kept in mind. Using the frequency of labeling in this series, Fig. 2 shows the hierarchical help that each of the markers can give in the assessment of a mammary origin of CK 5 positive TNBCs. It is clear from the figure as from overall data, that NY-BR-1 is not of great help in this context. BCA-225 which is breast specific only in its name and data-sheet, stained only $25 / 76$ of the tumors negative for all 4 other markers.

\section{Discussion}

TNBCs are defined by their negativity for ER, PR and HER2. Despite this defining phenotypic character, they still represent a heterogeneous group of breast carcinomas [48]. Some
Table 1 Details of the antibody used for IHC

\begin{tabular}{llll}
\hline Antibody & Source & Clone / Catalog number & Dilution \\
\hline GATA3 & Santa Cruz, Dallas, TX & HG3-31 / sc-268 & $1: 50$ \\
MG & Biocare, Concord, CA & 1A5 / PM 269 AA, H & RTU \\
GCDFP-15 & Cell Marque, Rocklin, CA & 23A3 / CMC791 & $1: 200$ \\
NY-BR-1 & Thermo-Fisher, Rockford, IL & NY-BR1\#2 / MS-1932-P0 & $1: 300$ \\
BCA-225 & Biogenex, Fremont, CA & CU18 / AM135-5 M & RTU \\
\hline
\end{tabular}

RTU: ready to use 
Table 2 Basic pathologic features of the tumors selected for TMA

\begin{tabular}{ll}
\hline Histological type & $\mathrm{n}(\%)$ \\
\hline No special type (ductal) & $106(92.3 \%)$ \\
Medullary-like & $7(6.1 \%)$ \\
Metaplastic ("matrix producing") carcinoma & $1(0.8 \%)$ \\
Mixed micropapillary carcinoma & $1(0.8 \%)$ \\
Histological grade & \\
Grade III & $112(97.3 \%)$ \\
Grade II & $3(2.7 \%)$ \\
(y)(r)pT category of the tumors & \\
Tx & $1(0.8 \%)$ \\
T0* & $1(0.8 \%)$ \\
T1b or c & $57(49.6 \%)$ \\
T2 & $47(40.9 \%)$ \\
T3 & $3(2.7 \%)$ \\
T4 & $6(5.2 \%)$ \\
Nodal status (y)(r)pN category of the tumors & \\
Nx & $3(2.7 \%)$ \\
N0** & $66(57.4 \%)$ \\
N1*** & $33(28.7 \%)$ \\
N2 & $9(7.8 \%)$ \\
N3 & $4(3.4 \%)$ \\
\hline
\end{tabular}

(y)(r)pT and (y)(r)pN categories refer to the TNM classification based $\mathrm{pT}$ and $\mathrm{pN}$ categories of primary tumors $(n=101)$ together with those of recurrent tumors (r, $n=4)$ and tumors after primary (i.e. neoadjuvant) systemic treatment $(\mathrm{y}, n=10)$. One case with intramammary nodal recurrence; $* *$ including 4 patients with isolated tumor cells; *** including 10 cases with micrometastasis.

subsets of TNBCs can be relatively well identified using IHC, for example androgen receptor and diffuse GCDFP-15 positivity can identify apocrine carcinomas [49], and it has been suggested that tumors expressing CK5 and/or EGFR are those that best match the molecular subtype of basal-like carcinomas [50]. Basal-like TNBCs are often circumscribed (a feature shared by many metastases), predominantly solid, without much lumen-forming tendency, and they often feature necrosis, squamous metaplasia, all rendering their identification as breast carcinoma more difficult. They are aggressive tumors with a tendency to give distant metastases on the short term. Metastases to the breast are rare, but metastases from TNBCs are relatively common. Identification of a tumor as primary TNBC or a metastasis from TNBC is relevant diagnostically, therapeutically, but can also be important from tissue archival and tumor banking aspects too.

Proving the mammary origin of TNBCs may be problematic, as ER, one of the most commonly used, but not specific markers of breast origin is by definition absent in these tumors. In the present study we investigated the expression of 5 markers developed or used to support the mammary origin of cancers according to the descriptions in the data sheets, (namely GATA-3, MG, GCDFP-15, NY-BR-1 and BCA-

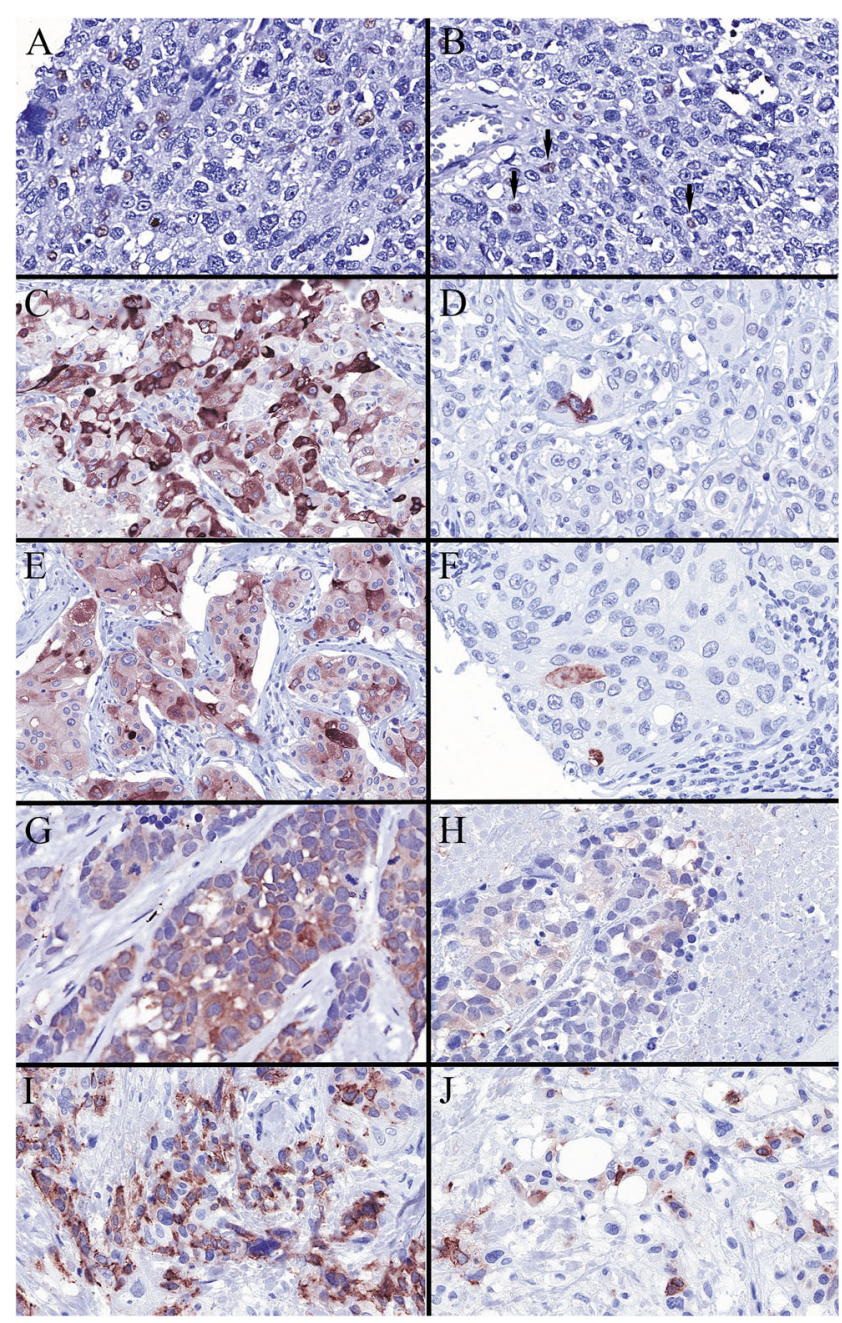

Fig. 1 Examples of noticeable (at least 5\%) GATA-3, Mammaglobin-A, GCDFP-15, NY-BR-1 and BCA-225 staining on the left (a, c, e, g, i, respectively) as opposed to focal and weak staining with these markers (b, $\mathbf{d}, \mathbf{f}, \mathbf{h}, \mathbf{j}$, respectively) on the right. Arrows in B indicate the few weakly stained nuclei

225) by IHC in a series of TNBCs deemed to be of the basal-like type on the basis of their CK5 expression.

Using the 5\% cut-off which is readily detectable, BCA-225 showed the highest expression rate with about one third of the cases staining, but this was well below the $98 \%$ staining rate found for breast cancers in general. Therefore, despite not being specific for breast cancer, the marker is also not sensitive enough. Owing to these features, it was dropped from further considerations.

Overall, more than $90 \%$ of breast cancers are GATA3 positive [45], whereas only about $50 \%, 20$ to $30 \%$ and $46-70 \%$ show positivity for MG [30], GCDFP-15 and NY-BR1 [44, 45], respectively. Most of the reported series suggest that positivity for both GATA3 and NY-BR-1 is more common in ERpositive tumors. GATA3 somatic mutations and microarray data have linked GATA3 to the estrogen signaling pathway, and therefore it is not surprising that the expression of this 
Table 3 Breast marker expressions in the tumors investigated

\begin{tabular}{lll}
\hline Marker & $\begin{array}{l}\text { Any positive staining }(\% ; 95 \% \mathrm{CI}) \\
n=115\end{array}$ & $\begin{array}{l}>5 \% \text { positive staining }(\%) \\
n=115\end{array}$ \\
\hline GATA3 & $82(71.3 ; 0.624-0.787)$ & $23(20 ; 0.137-0.282)$ \\
MG & $30(26.0 ; 0.189-0.348)$ & $12(10.4 ; 0.060-0.173)$ \\
GCDFP-15 & $23(20.0 ; 0.137-0.282)$ & $9(7.8 ; 0.041-0.142)$ \\
NY-BR-1 & $7(6.0 ; 0.029-0.120)$ & $3(2.6,0.008-0.073)$ \\
BCA-225 & $74(64.3 ; 0.552-0.725)$ & $40(34.7 ; 0.266-0.438)$ \\
GATA3 and MG & $21(18.2 ; 0.122-0.263)$ & $2(1.7,0.004-0.061)$ \\
MG and GCDFP-15 & $12(10.4 ; 0.060-0.173)$ & $2(1.7,0.004-0.061)$ \\
GATA-3, MG and GCDFP-15 & $9(7.8 ; 0.041-0.142)$ & $1(0.87 ; 0.001-0.047)$ \\
NY-BR-1 and GATA-3 & $3(2.6,0.008-0.073)$ & $0(0 ; 0.000-0.031)$ \\
Ny-BR-1 and GCDFP-15 & $2(1.7,0.004-0.061)$ & $2(1.7,0.004-0.061)$ \\
Any markers (without BCA-225) & $97(84.3 ; 0.766-0.898)$ & $40(34.7 ; 0.266-0.438)$ \\
\hline
\end{tabular}

CI: confidence interval

protein is lower in TNBCs, than in ER+ tumors or breast cancers in general, in keeping with previous results (Table 5).

Data on the staining frequency of GATA3, MG, GCDFP15 and NY-BR-1 in TNBC are limited. Studies reporting on the expression of these markers on a relatively large number of primary or secondary TNBCs are summarized in Table 5. On the basis of these data, the sensitivity of GATA-3, Mammaglobin-A, GCDFP-15 and NY-BR-1 to suggest a mammary origin are $43.5 \%$ (95\% CI $0.396-0.476), 16.4 \%$
(95\%CI: 0.136-0.196), 15.1\% (95\%CI: 0.127-0.179) and $5.4 \%$ (95\% CI: 0.027-0.103), respectively.

Despite the fact that GATA-3 expression has been linked with ER expression, this was the marker to show the highest frequency of staining in CK5 expressing TNBCs. When 5\% and more staining was chosen as a cut-off for positivity, the frequency of each marker decreased (Tables 3 and 4). Lower percentages of staining must be interpreted with caution as the specificity of such a low labeling is uncertain.

Table 4 Mutual breast marker expressions in the tumors investigated

\begin{tabular}{|c|c|c|c|c|c|c|c|c|}
\hline Any staining & GATA3+ & GATA3- & MG+ & MG- & GCDFP-15+ & GCDFP-15- & NY-BR-1+ & NY-BR-1- \\
\hline \multicolumn{9}{|l|}{ GATA3+ } \\
\hline GATA3- & na & & & & & & & \\
\hline MG+ & 21 & 8 & & & & & & \\
\hline MG- & 61 & 25 & na & & & & & \\
\hline GCDFP-15+ & 16 & 6 & 11 & 11 & & & & \\
\hline GCDFP-15- & 66 & 27 & 18 & 75 & na & & & \\
\hline NY-BR-1+ & 2 & 3 & 0 & 5 & 1 & 4 & & \\
\hline NY-BR-1- & 80 & 30 & 29 & 81 & 21 & 89 & na & \\
\hline BCA225+ & 57 & 16 & 23 & 50 & 16 & 57 & 3 & 70 \\
\hline BCA225- & 25 & 17 & 6 & 36 & 6 & 36 & 2 & 40 \\
\hline $5 \%$ cut-off & GATA3+ & GATA3- & MG+ & MG- & GCDFP-15+ & GCDFP-15- & NY-BR-1+ & NY-BR-1- \\
\hline \multicolumn{9}{|l|}{ GATA3+ } \\
\hline GATA3- & na & & & & & & & \\
\hline MG+ & 2 & 10 & & & & & & \\
\hline MG- & 21 & 82 & na & & & & & \\
\hline GCDFP-15+ & 2 & 6 & 2 & 6 & & & & \\
\hline GCDFP-15- & 21 & 86 & 10 & 97 & na & & & \\
\hline NY-BR-1+ & 0 & 1 & 0 & 1 & 0 & 1 & & \\
\hline NY-BR-1- & 23 & 91 & 12 & 102 & 8 & 106 & na & \\
\hline BCA225+ & 8 & 31 & 4 & 35 & 4 & 35 & 0 & 39 \\
\hline BCA225- & 15 & 61 & 8 & 68 & 4 & 72 & 1 & 75 \\
\hline
\end{tabular}




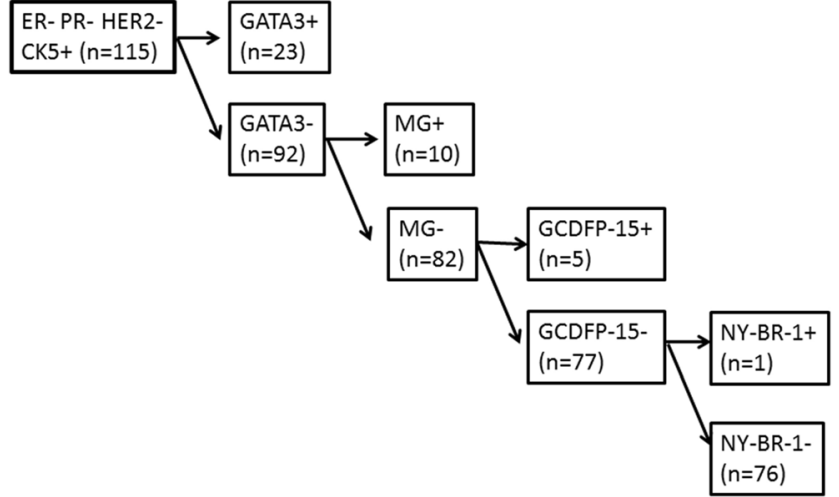

Fig. 2 Hierarchical labeling of the tumors with 4 "breast specific" markers

When our results are compared with those of others (Table 5), the positivity rates for GATA-3, and GCDFP-15 are lower in our TMA based series. A potential weakness of the present study could be the use of TMAs, because MG and GCDFP-15 often stain breast carcinomas in a patchy pattern [32], and the sensitivity of detecting these markers can be lower in TMAs than on whole slide sections. This could be one possible cause of the discrepancy between our results and those of others listed in Table 5, although two 2-mm- diameter cores are a relatively good representation of a tumor in TMA based studies. Another issue behind the difference in results might stem from the fact, that we studied a distinct subset of TNBCs.

TNBCs are heterogeneous [48], and some of them, belonging to the luminal androgen receptor positive group, are characterized by forkhead-box A1 (FOXA1) protein overexpression [51]. FOXA1 and GATA-3 are both involved in the downstream of the ER pathway. Diffuse GCDPF-15 is also a marker of apocrine differentiation in IHC studies [49, 52]. Such tumors were excluded by selecting basal-like matching carcinomas on the basis of their CK5 expression. Such differences in the subgroups analyzed may also contribute to the lower rates of positivity of GATA-3 and GCDFP-15 in this series; it is believed that this is the main reason for the discrepancy.

Possible differences may also be attributable to the use of different antibodies/clones. But this is unlikely to be a major source of differences as 4 studies used the same antibody clones as we used for GATA3 [6, 7, 53, 54]. The fact that we studied primary tumors rather than metastases is also unlikely to explain lower expression rates in the present series. The evaluation of primary tumors may be a limitation of the present study due to possible changes of phenotype between a

Table 5 Summary of results from other series exploring the labeling of TNBCs

\begin{tabular}{|c|c|c|c|c|c|c|}
\hline Author (year) & cut off & Tumor type & GATA-3 & $\mathrm{MG}$ & GCDFP-15 & NY-BR-1 \\
\hline Ordonez et al. [11] & any staining & metastatic TNBC & $12 / 40(30 \%)$ & $7 / 40(17.5 \%)$ & $6 / 40(15 \%)$ & -- \\
\hline Krings et al. [54] & any staining & primary $\mathrm{TNBC}$ & $72 / 109(66 \%)$ & $28 / 107(26.1 \%)$ & $17 / 109(15.5 \%)$ & -- \\
\hline Braxton et al. [55] & $>10 \%$ & metastatic TNBC & $30 / 35(85.7 \%)$ & $9 / 35(25.7 \%)$ & $5 / 35(14.2 \%)$ & -- \\
\hline \multirow[t]{2}{*}{ Cimino-Matthews et al. [19] } & $>5 \%$ & primary TNBC & $19 / 44(43.1 \%)$ & -- & -- & -- \\
\hline & & metastatic TNBC & $5 / 9(55.5 \%)$ & -- & -- & -- \\
\hline Lew et al. [56] & any staining & metastatic TNBC & $11 / 13(84.6 \%)$ & $4 / 13(30.7 \%)$ & $1 / 13(7.6 \%)$ & -- \\
\hline \multirow[t]{4}{*}{ Huo et al. [6] } & any staining & primary TNBC & $25 / 62(40.3 \%)$ & $16 / 62(25.8 \%)$ & $9 / 62(14.5 \%)$ & -- \\
\hline & $>5 \%$ & & $14 / 62(22.58 \%)$ & 7/62 (11.2\%) & 4/62 (6.4\%) & \\
\hline & any staining & metastatic TNBC & $30 / 68(44.1 \%)$ & $22 / 68(32.3 \%)$ & $11 / 68(16.1 \%)$ & -- \\
\hline & $>5 \%$ & & $18 / 68(26.4 \%)$ & $10 / 68(14.7 \%)$ & $6 / 68(8.8 \%)$ & \\
\hline Lewis et al. [32] & any staining & $\begin{array}{l}\text { primary basal-like } \\
\text { TNBC }\end{array}$ & -- & $5 / 24(20.8 \%)$ & $1 / 5(20 \%)$ & -- \\
\hline Rakhshani et al. [57] & $>10 \%$ & $\begin{array}{l}\text { primary basal-like } \\
\text { TNBC }\end{array}$ & - & $6 / 66(9 \%)$ & $12 / 66(18.1 \%)$ & -- \\
\hline Darb-Esfahani et al. [58] & any staining & primary TNBC & -- & -- & $34 / 130(26.1 \%)$ & -- \\
\hline Pala et al. [59] & $>5 \%$ & primary TNBC & -- & -- & $8 / 41(19.5 \%)$ & -- \\
\hline Deftereos et al. [7] & H-score 99.4 & primary TNBC & $7 / 28(25 \%)$ & $2 / 28(7.1 \%)$ & $5 / 28(17.8 \%)$ & -- \\
\hline Clark et al. [60] & at least $4 \%$ & primary TNBC & $22 / 30(73.3 \%)$ & -- & -- & -- \\
\hline Gloyeske et al. [61] & $\begin{array}{l}\text { any staining } \\
>10 \mathrm{H} \text {-score }\end{array}$ & primary $\mathrm{TNBC}$ & $22 / 30(73 \%)$ & $6 / 31(19 \%)$ & $5 / 32(16 \%)$ & $5 / 30(17 \%)$ \\
\hline \multirow[t]{2}{*}{ Our work } & any staining & primary & $82 / 115(71.3 \%)$ & $30 / 115(26.0 \%)$ & $23 / 115(20.0 \%)$ & $7 / 115(6.0 \%)$ \\
\hline & $>5 \%$ & $\begin{array}{l}\text { (or recurrent) } \\
\text { TNBC }\end{array}$ & $23 / 115(20.0 \%)$ & $12 / 115(10.4 \%)$ & 9/115 (7.8\%) & $3 / 115(2.6 \%)$ \\
\hline Sensitivity; 95\% CI* & & & $43.7 \% ; 0.397-0.477$ & $16.3 \% ; 0.135-0.195$ & $15,1 \% ; 0,127-0,179$ & $5.5 \% ; 0.028-0.105$ \\
\hline
\end{tabular}

*For calculating sensitivity values, all publications with data were considered, and whenever there were data with two staining cut-offs, the $>5 \%$ data were included only. 
primary tumor and its metastases, but if primary basal-like TNBCs show such a low expression of the studied markers, expecting much wider immunoreaction in metastases would seem unrealistic.

To our knowledge, this is the largest series of TNBC analyzed for the expression of 4 markers of mammary origin, moreover the series includes exclusively TNBC of a distinct subtype, namely tumors expressing CK5 and therefore most likely to coincide with basal-like breast carcinomas [50]. If we consider the documented lack of specificity of BCA-225 [47], the remaining 4 breast markers fail to show any staining in about $15 \%$ of CK 5 expressing TNBCs. A more detectable (at least $5 \%$ ) expression of any of the 4 markers was seen in around one third of the cases, leaving the remaining two thirds unidentified as of mammary origin. Of the 4 markers, NY-BR1 is rarely expressed in the tumor subset studied, and therefore its use adds practically nothing to the use of the other three.

The expression of GATA3, MG, GCDFP-15 and NY-BR-1 is lower in TNBCs than in breast carcinomas in general. Although these markers may be positive in different other tumors, by using them, a subset of basal-like TNBC-s can be identified as of mammary origin. Though the positive staining supports a breast origin, negativity for all markers does not exclude this. Therefore we suggest using GATA-3, MG and GCDFP-15 as an IHC panel to establish breast origin when ER and PR are negative. Obviously, at the primary site, histological features such as the presence of in situ carcinoma of similar grade may also suggest the primary nature of the tumor, but this help is missing in the metastatic setting. One should be prepared to find a relatively high number of basallike TNBCs to be negative for all the studied breast markers.

Acknowledgements This study was funded by the National Research, Development and Innovation Office grant GINOP-2.3.2-15-2016-00020.

\section{Compliance with Ethical Standards}

Conflict of Interest No editorial or financial conflicts of interest exist for this submission.

\section{References}

1. DeSantis C, Ma J, Bryan L, Jemal A (2013) Breast cancer statistics, 2013. CA Cancer J Clin 64:52-62. doi:10.3322/caac.21203

2. Malvezzi M, Carioli G, Bertuccio P, Rosso T, Boffetta P, Levi F, La Vecchia C, Negri E (2016) European cancer mortality predictions for the year 2016 with focus on leukaemias. Ann Oncol 27:725731. doi:10.1093/annonc/mdw022

3. Perou CM, Sørlie T, Eisen MB, van de Rijn M, Jeffrey SS, Rees CA, Pollack JR, Ross DT, Johnsen H, Akslen LA, Fluge O, Pergamenschikov A, Williams C, Zhu SX, Lønning PE, Børresen-Dale AL, Brown PO, Botstein D (2000) Molecular portraits of human breast tumours. Nature 406:747-752
4. Nielsen TO, Perou CM (2015) CCR 20th anniversary commentary: the development of breast cancer molecular subtyping. Clin Cancer Res 21:1779-1781. doi:10.1158/1078-0432.CCR-14-2552

5. Hernandez BY, Green MD, Cassel KD, Pobutsky AM, Vu V, Wilkens LR (2010) Preview of Hawaii cancer facts and figures. Hawaii Med J 69:223-224

6. Huo L, Gong Y, Guo M, Gilcrease MZ, Wu Y, Zhang H, Zhang J, Resetkova E, Hunt KK, Deavers MT (2015) GATA-binding protein 3 enhances the utility of gross cystic disease fluid protein-15 and mammaglobin a in triple-negative breast cancer by immunohistochemistry. Histopathology 67:245-254. doi:10.1111/his.12645

7. Deftereos G, Sanguino Ramirez AM, Silverman JF, Krishnamurti U (2015) GATA3 immunohistochemistry expression in histologic subtypes of primary breast carcinoma and metastatic breast carcinoma cytology. Am J Surg Pathol 39:1282-1289. doi:10.1097/ PAS.0000000000000505

8. Chou J, Provot S, Werb Z (2010) GATA3 in development and cancer differentiation: cells GATA have it! J Cell Physiol 222:4249. doi:10.1002/jcp. 21943

9. Esheba GE, Longacre TA, Atkins KA, Higgins JP (2009) Expression of the urothelial differentiation markers GATA3 and placental S100 (S100P) in female genital tract transitional cell proliferations. Am J Surg Pathol 33:347-353

10. Liu H, Shi J, Wilkerson ML, Lin F (2012) Immunohistochemical evaluation of GATA3 expression in tumors and normal tissues: a useful immunomarker for breast and urothelial carcinomas. Am J Clin Pathol 138:57-64. doi:10.1309/AJCP5UAFMSA9ZQBZ

11. Ordonez NG (2013) Value of GATA3 immunostaining in tumor diagnosis: a review. Adv Anat Pathol 20:352-360. doi:10.1097/ PAP.0b013e3182a28a68

12. Miettinen M, McCue PA, Sarlomo-Rikala M, Rys J, Czapiewski P, Wazny K, Langfort R, Waloszczyk P, Biernat W, Lasota J, Wang Z (2014) GATA3: a multispecific but potentially useful marker in surgical pathology: a systematic analysis of 2500 epithelial and nonepithelial tumors. Am J Surg Pathol 38:13-22. doi:10.1097/ PAS.0b013e3182a0218f

13. Voduc D, Cheang M, Nielsen T (2008) GATA-3 expression in breast cancer has a strong association with estrogen receptor but lacks independent prognostic value. Cancer Epidemiol Biomark Prev 17:365-373. doi:10.1158/1055-9965.EPI-06-1090

14. Hoch RV, Thompson DA, Baker RJ, Weigel RJ (1999) GATA-3 is expressed in association with estrogen receptor in breast cancer. Int J Cancer 84:122-128

15. Tominaga N, Naoi Y, Shimazu K, Nakayama T, Maruyama N, Shimomura A, Kim SJ, Tamaki Y, Noguchi S (2012) Clinicopathological analysis of GATA3-positive breast cancers with special reference to response to neoadjuvant chemotherapy. Ann Oncol 23:3051-3057. doi:10.1093/annonc/mds120

16. Albergaria A, Paredes J, Sousa B, Milanezi F, Carneiro V, Bastos J, Costa S, Vieira D, Lopes N, Lam EW, Lunet N, Schmitt F (2009) Expression of FOXA1 and GATA-3 in breast cancer: the prognostic significance in hormone receptor-negative tumours. Breast Cancer Res 11:R40. doi:10.1186/bcr2327

17. Parikh P, Palazzo JP, Rose LJ, Daskalakis C, Weigel RJ (2005) GATA-3 expression as a predictor of hormone response in breast cancer. J Am Coll Surg 200:705-710

18. Mehra R, Varambally S, Ding L, Shen R, Sabel MS, Ghosh D, Chinnaiyan AM, Kleer CG (2005) Identification of GATA3 as a breast cancer prognostic marker by global gene expression metaanalysis. Cancer Res 65:11259-11264

19. Cimino-Mathews A, Subhawong AP, Illei PB, Sharma R, Halushka MK, Vang R, Fetting JH, Park BH, Argani P (2013) GATA3 expression in breast carcinoma: utility in triple-negative, sarcomatoid, and metastatic carcinomas. Hum Pathol 44:1341-1349. doi:10. 1016/j.humpath.2012.11.003 
20. Ciocca V, Daskalakis C, Ciocca RM, Ruiz-Orrico A, Palazzo JP (2009) The significance of GATA3 expression in breast cancer: a 10-year follow-up study. Hum Pathol 40:489-495. doi:10.1016/j. humpath.2008.09.010

21. Jacquemier J, Charafe-Jauffret E, Monville F, Esterni B, Extra JM, Houvenaeghel G, Xerri L, Bertucci F, Birnbaum D (2009) Association of GATA3, P53, Ki67 status and vascular peritumoral invasion are strongly prognostic in luminal breast cancer. Breast Cancer Res 11:R23. doi:10.1186/bcr2249

22. Demir H, Turna H, Can G, Ilvan S (2010) Clinicopathologic and prognostic evaluation of invasive breast carcinoma molecular subtypes and GATA3 expression. J Buon 15:774-782

23. Watson MA, Fleming TP (1996) Mammaglobin, a mammaryspecific member of the uteroglobin gene family, is overexpressed in human breast cancer. Cancer Res 56:860-865

24. Watson MA, Darrow C, Zimonjic DB, Popescu NC, Fleming TP (1998) Structure and transcriptional regulation of the human mammaglobin gene, a breast cancer associated member of the uteroglobin gene family localized to chromosome $11 \mathrm{q} 13$. Oncogene 16:817-824

25. Han JH, Kang Y, Shin HC, Kim HS, Kang YM, Kim YB, Oh SY (2003) Mammaglobin expression in lymph nodes is an important marker of metastatic breast carcinoma. Arch Pathol Lab Med 127: $1330-1334$

26. Bhargava R, Beriwal S, Dabbs DJ (2007) Mammaglobin vs GCDFP-15: an immunohistologic validation survey for sensitivity and specificity. Am J Clin Pathol 127:103-113

27. Zafrakas M, Petschke B, Donner A, Fritzsche F, Kristiansen G, Knüchel R, Dahl E (2006) Expression analysis of mammaglobin a (SCGB2A2) and lipophilin B (SCGB1D2) in more than 300 human tumors and matching normal tissues reveals their coexpression in gynecologic malignancies. BMC Cancer 6:88

28. Sasaki E, Tsunoda N, Hatanaka Y, Mori N, Iwata H, Yatabe Y (2007) Breast-specific expression of MGB1/mammaglobin: an examination of 480 tumors from various organs and clinicopathological analysis of MGB1-positive breast cancers. Mod Pathol 20:208214

29. Wang Z, Spaulding B, Sienko A, Liang Y, Li H, Nielsen G, Yub Gong G, Ro JY, Jim Zhai Q (2009) Mammaglobin, a valuable diagnostic marker for metastatic breast carcinoma. Int J Clin Exp Pathol 2:384-389

30. Onuma K, Dabbs DJ, Bhargava R (2008) Mammaglobin expression in the female genital tract: immunohistochemical analysis in benign and neoplastic endocervix and endometrium. Int J Gynecol Pathol 27:418-425. doi:10.1097/PGP.0b013e31815d05ec

31. Al-Joudi FS, Kaid FA, Ishak I, Mohamed N, Osman K, Alias IZ (2011) Expression of human mammaglobin and clinicopathologic correlations in breast cancer: the findings in Malaysia. Indian $\mathrm{J}$ Pathol Microbiol 54:284-289. doi:10.4103/0377-4929.81596

32. Lewis GH, Subhawong AP, Nassar H, Vang R, Illei PB, Park BH, Argani P (2011) Relationship between molecular subtype of invasive breast carcinoma and expression of gross cystic disease fluid protein 15 and mammaglobin. Am J Clin Pathol 135:587-591. doi: 10.1309/AJCPMFR6OA8ICHNH

33. Fritzsche FR, Thomas A, Winzer KJ, Beyer B, Dankof A, Bellach J, Dahl E, Dietel M, Kristiansen G (2007) Co-expression and prognostic value of gross cystic disease fluid protein 15 and mammaglobin in primary breast cancer. Histol Histopathol 22: $1221-1230$

34. Haagensen DE Jr, Mazoujian G, Holder WD Jr, Kister SJ, Wells SA $\mathrm{Jr}$ (1977) Evaluation of a breast cyst fluid protein detectable in the plasma of breast carcinoma patients. Ann Surg 185:279-285

35. Wick MR, Lillemoe TJ, Copland GT, Swanson PE, Manivel JC, Kiang DT (1989) Gross cystic disease fluid protein-15 as a marker for breast cancer: immunohistochemical analysis of 690 human neoplasms and comparison with alpha-lactalbumin. Hum Pathol 20:281-287

36. Park SY, Kim BH, Kim JH, Lee S, Kang GH (2007) Panels of immunohistochemical markers help determine primary sites of metastatic adenocarcinoma. Arch Pathol Lab Med 131:1561-1567

37. Jäger D, Stockert E, Güre AO, Scanlan MJ, Karbach J, Jäger E, Knuth A, Old LJ, Chen YT (2001) Identification of a tissue-specific putative transcription factor in breast tissue by serological screening of a breast cancer library. Cancer Res 61:2055-2061

38. Jäger D, Filonenko V, Gout I, Frosina D, Eastlake-Wade S, Castelli S, Varga Z, Moch H, Chen YT, Busam KJ, Seil I, Old LJ, Nissan A, Frei C, Gure AO, Knuth A, Jungbluth AA (2007) NY-BR-1 is a differentiation antigen of the mammary gland. Appl Immunohistochem Mol Morphol 15:77-83

39. Giger OT, Lacoste E, Honegger C, Padberg B, Moch H, Varga Z (2007) Expression of the breast differentiation antigen NY-BR-1 in a phyllodes tumor of the vulva. Virchows Arch 450:471-474

40. Varga Z, Theurillat JP, Filonenko V, Sasse B, Odermatt B, Jungbluth AA, Chen YT, Old LJ, Knuth A, Jäger D, Moch H (2006) Preferential nuclear and cytoplasmic NY-BR-1 protein expression in primary breast cancer and lymph node metastases. Clin Cancer Res 12:2745-2751

41. Theurillat JP, Zürrer-Härdi U, Varga Z, Storz M, Probst-Hensch NM, Seifert B, Fehr MK, Fink D, Ferrone S, Pestalozzi B, Jungbluth AA, Chen YT, Jäger D, Knuth A, Moch H (2007) NYBR-1 protein expression in breast carcinoma: a mammary gland differentiation antigen as target for cancer immunotherapy. Cancer Immunol Immunother 56:1723-1731

42. Seil I, Frei C, Sültmann H, Knauer SK, Engels K, Jäger E, Zatloukal K, Pfreundschuh M, Knuth A, Tseng-Chen Y, Jungbluth AA, Stauber RH, Jäger D (2007) The differentiation antigen NY-BR-1 is a potential target for antibody-based therapies in breast cancer. Int J Cancer 120:2635-2642

43. Woodard AH, Yu J, Dabbs DJ, Beriwal S, Florea AV, Elishaev E, Davison JM, Krasinskas AM, Bhargava R (2011) NY-BR-1 and PAX8 immunoreactivity in breast, gynecologic tract, and other $\mathrm{CK} 7+$ carcinomas: potential use for determining site of origin. Am J Clin Pathol 136:428-435. doi:10.1309/ AJCPUFNMEZ3MK1BK

44. Balafoutas D, zur Hausen A, Mayer S, Hirschfeld M, Jaeger M, Denschlag D, Gitsch G, Jungbluth A, Stickeler E (2013) Cancer testis antigens and NY-BR-1 expression in primary breast cancer: prognostic and therapeutic implications. BMC Cancer 13:271. doi: 10.1186/1471-2407-13-271

45. Liu H (2014) Application of immunohistochemistry in breast pathology: a review and update. Arch Pathol Lab Med 138:16291642. doi:10.5858/arpa.2014-0094-RA

46. Mesa-Tejada R, Palakodety RB, Leon JA, Khatcherian AO, Greaton CJ (1988) Immunocytochemical distribution of a breast carcinoma associated glycoprotein identified by monoclonal antibodies. Am J Pathol 130:305-314

47. Loy TS, Chapman RK, Diaz-Arias AA, Bulatao IS, Bickel JT (1991) Distribution of BCA-225 in adenocarcinomas. An immunohistochemical study of 446 cases. Am J Clin Pathol 96:326-329

48. Abramson VG, Lehmann BD, Ballinger TJ, Pietenpol JA (2015) Subtyping of triple-negative breast cancer: implications for therapy. Cancer 121:8-16. doi:10.1002/cncr.28914

49. Vranic S, Schmitt F, Sapino A, Costa JL, Reddy S, Castro M, Gatalica Z (2013) Apocrine carcinoma of the breast: a comprehensive review. Histol Histopathol 28:1393-1409. doi:10.14670/HH28.1393

50. Nielsen TO, Hsu FD, Jensen K, Cheang M, Karaca G, Hu Z, Hernandez-Boussard T, Livasy C, Cowan D, Dressler L, Akslen LA, Ragaz J, Gown AM, Gilks CB, van de Rijn M, Perou CM (2004) Immunohistochemical and clinical characterization of the 
basal-like subtype of invasive breast carcinoma. Clin Cancer Res 10:5367-5374

51. Sasahara M, Matsui A, Ichimura Y, Hirakata Y, Murata Y, Marui E (2014) Overexpression of androgen receptor and forkhead-box A1 protein in apocrine breast carcinoma. Anticancer Res 34:12611267

52. Kővári B, Rusz O, Schally AV, Kahán Z, Cserni G (2014) Differential immunostaining of various types of breast carcinomas for growth hormone-releasing hormone (GHRH) receptor - apocrine epithelium and carcinomas emerging as uniformly positive. APMIS 122:824-831. doi:10.1111/apm.12224

53. Ordonez NG, Sahin AA (2014) Diagnostic utility of immunohistochemistry in distinguishing between epithelioid pleural mesotheliomas and breast carcinomas: a comparative study. Hum Pathol 45: 1529-1540. doi:10.1016/j.humpath.2014.03.006

54. Krings G, Nystrom M, Mehdi I, Vohra P, Chen YY (2014) Diagnostic utility and sensitivities of GATA3 antibodies in triplenegative breast cancer. Hum Pathol 45:2225-2232. doi:10.1016/j. humpath.2014.06.022

55. Braxton DR, Cohen C, Siddiqui MT (2015) Utility of GATA3 immunohistochemistry for diagnosis of metastatic breast carcinoma in cytology specimens. Diagn Cytopathol 43:271-277. doi:10.1002/ dc. 23206

56. Lew M, Pang JC, Jing X, Fields KL, Roh MH (2015) Young investigator challenge: the utility of GATA3 immunohistochemistry in the evaluation of metastatic breast carcinomas in malignant effusions. Cancer Cytopathol 123:576-581. doi:10.1002/cncy.21574

57. Rakhshani N, Daryakar A (2014) Are mammaglobin and GCDFP15 sensitive markers for diagnosis of metastatic basal-like triple negative breast carcinomas? Turk Patoloji Derg 30:18-22. doi:10. 5146/tjpath.2013.01202

58. Darb-Esfahani S, von Minckwitz G, Denkert C, Ataseven B, Högel B, Mehta K, Kaltenecker G, Rüdiger T, Pfitzner B, Kittel K, Fiedler B, Baumann K, Moll R, Dietel M, Eidtmann H, Thomssen C, Loibl S (2014) Gross cystic disease fluid protein 15 (GCDFP-15) expression in breast cancer subtypes. BMC Cancer 14:546. doi:10.1186/ 1471-2407-14-546

59. Pala EE, Bayol Ü, Cumurcu S, Keskın E (2012) Immunohistochemical characteristics of triple negative/basal-like breast cancer. Turk Patoloji Derg 28:238-244. doi:10.5146/tjpath. 2012.01130

60. Clark BZ, Beriwal S, Dabbs DJ, Bhargava R (2014) Semiquantitative GATA-3 immunoreactivity in breast, bladder, gynecologic tract, and other cytokeratin 7-positive carcinomas. Am J Clin Pathol 142:64-71. doi:10.1309/AJCP8H2VBDSCIOBF

61. Gloyeske NC1, Woodard AH, Elishaev E, Yu J, Clark BZ, Dabbs DJ, Bhargava R (2015) Immunohistochemical profile of breast cancer with respect to estrogen receptor and HER2 status. Appl Immunohistochem Mol Morphol 23:202-208. doi:10.1097/PAI. 0000000000000076 
II. Cserni G, Zombori T, Andreu X, Bianchi S, Regitnig P, Amendoeira I, Balmativola D, Kovács A, Cordoba A, Reiner A, Kulka J, Kaya H, Liepniece-Karele I, Quinn C, Kővári B. Is regression after neoadjuvant chemotherapy for locally advanced breast cancer different in sentinel and non-sentinel nodes? Pathol Oncol Res. 2018;24:167-170. doi: 10.1007/s12253017-0229-z.

IF: 1.93 


\section{TÁRSSZERZŐI NYILATKOZAT}

Alulírott Prof. Dr. Cserni Gábor témavezető és első szerző igazolom, hogy Dr. Zombori Tamás (második szerző) az alább megnevezett közlemény alapjául szolgáló munkában, az adatgyüjtésében, a kézirat végeleges tartalmának kialakításában aktívan részt vett, ezáltal felhasználhatja a Challenges in the surgical pathological diagnosis of breast cancer (Kihívások az emlőrák patológiai diagnosztikájában) című doktori értekezésének részeként. Igazolom, hogy a közlemény más doktori értekezés, egyéb tudományos dolgozat alapját nem képezi.

\section{Közlemény:}

Cserni G, Zombori T, Andreu X, Bianchi S, Regitnig P, Amendoeira I, Balmativola D, Kovács A, Cordoba A, Reiner A, Kulka J, Kaya H, Liepniece-Karele I, Quinn C, Kővári B. Is regression after neoadjuvant chemotherapy for locally advanced breast cancer different in sentinel and non-sentinel nodes? Pathol Oncol Res. 2018;24:167-170.

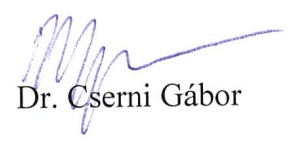

egyetemi tanár / témavezető

Szeged, 2018. 11. 08. 


\title{
Is Regression after Neoadjuvant Chemotherapy for Locally Advanced Breast Cancer Different in Sentinel and Non-sentinel Nodes?
}

\author{
Gábor Cserni $^{1,2}$ (1) $\cdot$ Tamás Zombori $^{2} \cdot$ Xavier Andreu $^{3} \cdot$ Simonetta Bianchi $^{4}$. \\ Peter Regitnig $^{5}$ - Isabel Amendoeira ${ }^{6}$ • Davide Balmativola ${ }^{7}$ - Anikó Kovács ${ }^{8}$. \\ Alicia Cordoba ${ }^{9}$ - Angelika Reiner ${ }^{10}$ • Janina Kulka ${ }^{11}$ - Handan Kaya ${ }^{12}$. \\ Inta Liepniece-Karele ${ }^{13}$. Cecily Quinn ${ }^{14}$ - Bence Kővári ${ }^{2}$
}

Received: 3 March 2017 / Accepted: 3 April 2017 /Published online: 8 April 2017

(C) Arányi Lajos Foundation 2017

\begin{abstract}
Tumor draining sentinel lymph nodes (SLNs) are the sites of selective changes as compared to non-SLNs. They show features of tumor-reactive lymphadenopathy, including increased total number of functional blood vessels, but a relative immunosuppressed status has also been described in them. We explored the hypothesis of a selective regression or non-regression in SLNs versus non-SLNs in 142 patients with 110 estrogen receptor-positive and 32 estrogen receptornegative tumors undergoing both SLN biopsy and axillary lymph node dissection after neoadjuvant therapy by assessing the tumoral (metastatic) and regression statuses of SLNs and non-SLNs separately. Of the 89 cases with signs of nodal regression, 22 cases $(25 \%)$ were in favor of a selective nonregression in SLNs, 18 cases (20\%) were supportive of a selective and more pronounced regression in the SLNs and the remaining showed equal degrees of regression or non-
\end{abstract}

Gábor Cserni

cserni@freemail.hu

1 Department of Pathology, Bács-Kiskun County Teaching Hospital, Nyiri ut 38, Kecskemét 6000, Hungary

2 Department of Pathology, University of Szeged, Állomás u 1, Szeged 6725, Hungary

3 Department of Pathology, Corporació Sanitària Parc Taulí, University Autònoma Barcelona, 08202 Sabadell, Spain

4 Division of Pathological Anatomy, Department of Surgery and Translational Medicine, AOU Careggi, Largo G. A. Brambilla 3, 50134 Florence, Italy

5 Institute of Pathology, Medical University of Graz, Auenbruggerplatz 25, A-8036 Graz, Austria

6 Laboratório de Anatomia Patológica, Centro Hospitalar de São João e IPATIMUP, 4440-563 Porto, Portugal regression in SLNs and non-SLNs. The results indicate that there is no obvious difference in the degree of regressive histological changes shown by SLNs and NSLNs. Therefore, this phenomenon may not be a major contributor to the higher false negative rate of SLN biopsy after neoadjuvant treatment.

Keywords Sentinel lymph node $\cdot$ Non-sentinel lymph node Breast cancer $\cdot$ Neoadjuvant therapy $\cdot$ Selective regression

\section{Introduction}

Lymph nodes are not identical. The sentinel lymph nodes (SLN) are the first lymph nodes draining the lymph from an anatomical site and therefore, in case of a cancer in the given area, the SLNs are the first involved during the lymphatic

7 Candiolo Cancer Institute - Fondazione del Piemonte per l'Oncologia (FPO), IRCCS, Str. Prov. 142, km 3.95, 10060 Candiolo, To, Italy

8 Department of Clinical Pathology and Genetics, Sahlgrenska University Hospital, Gula stråket 8, 41345 Gothenburg, Sweden

9 Department of Pathology, Complejo Hospitalario de Navarra, Irunlarrea 3, 31008 Pamplona, Navarra, Spain

10 Pathologisch-Bakteriologisches Institut, Donauspital am SMZO, Langobardenstraße, 122 Vienna, Austria

11 2nd Department of Pathology, Semmelweis University Budapest, Üllöi út 93, Budapest H-1091, Hungary

12 Department of Pathology, Marmara University, School of Medicine, Istanbul, Turkey

13 Pathology Centre, Riga East Clinical University Hospital, Hipokrata St 2, Riga LV-1038, Latvia

14 School of Medicine, University College Dublin, St. Vincent's University Hospital, Elm Park, Dublin 4, Ireland 
spread of cancer. The non-SLNs of the same anatomic region develop metastases only subsequently. Development of metastasis is not the only change known to occur in tumor draining lymph nodes. Tumor-reactive lymphadenopathy (TRL) is a complex reaction of lymph nodes, which develops before the arrival of the metastatic tumor cells and comprises morphological and functional changes. Enlargement of the tumor draining lymph nodes (also induced by needle biopsy of the primary cancer) has helped axillary four-node sampling [1], and may explain the possible overlap of axillary node samples and sentinel nodes [2]. As concerns the morphological alterations, previous publications found increased total number of functional blood vessels and lymphatic vessels/sinuses in tumor draining lymph nodes. Furthermore, some authors have described dilation of functional blood vessels with structural remodeling and endothelial cell proliferation of high endothelial venules [3]. Functional changes, such as increased blood perfusion and immunological differences, like the alterations in $\mathrm{CD} 28$ and $\mathrm{CD} 3 \zeta$ expression of CD4+ and CD8+ T-lymphocytes $[4,5]$ or the reduction in density and dendritic complexity of antigen presenting paracortical dendritic cells [6] were also observed in tumor draining lymph nodes. Tumor-induced immune modulation of the SLNs versus the non-SLNs seems to act in favor of a reduced anti-tumoral immune reaction [6].

The above-mentioned factors may hypothetically alter the neoadjuvant therapy induced reactions in tumor-draining SLNs compared to lymph nodes without direct connection with the primary carcinoma, i.e. non-SLNs. Enhanced blood flow and enriched vasculature may increase the load of chemotherapeutics or targeted cancer therapy agents (e.g. hormone receptor modulators or trastuzumab) in lymph nodes developing TRL. A preferential regression in SLNs might influence the false negative rate of SLN biopsy after primary systemic treatment, by resulting in complete regression in SLNs with remaining tumor burden in non-SLNs. Alternatively an immunosuppressed status of the SLNs as compared to non-SLNs could lead to less effect from cytotoxic therapeutics. A selective regression or non-regression may also alter the staging effect of the removal of radioactive seed localized nodes that proved to be positive before the initiation of primary systemic treatment [7].

Along this hypothesis, differences in the degree of regression induced by neoadjuvant therapy in the SLNs (tumor draining lymph nodes) and in non-SLNs (non-tumor draining lymph nodes) were looked for in a series of patients who underwent SLN biopsy and axillary lymph node dissection (ALND) following neoadjuvant systemic therapy for breast cancer.

\section{Materials and Methods}

In this retrospective study, lymph node tissue sections of 142 female breast cancer patients staged with SLN biopsy and ALND after receiving neoadjuvant therapy were used from the archives of the authors' institutions. Inclusion criteria for enrollment were any type of histologically verified invasive primary breast cancer treated with neoadjuvant systemic therapy, the successful identification of at least one SLN and ALND following SLN biopsy. SLNs were identified according to the routine procedure of the given institutions, and involved intra- or peritumoral or subareolar injection of a $99 \mathrm{mTc}$ labelled colloidal albumin and/or Patent blue dye in vivo. ALND was performed either routinely as part of a validation of SLN biopsy after neoadjuvant treatment or because of metastatic disease identified in the SLNs.

Tissues were fixed in buffered formalin and embedded in paraffin. Three to four-micrometer-thick whole tissue sections were used for the standard hematoxylineosin staining. The presence and degree of regression were evaluated in all metastatic and non-metastatic lymph nodes, SLNs and non-SLNs separately, using the nodal regression (NR) grading recommended by the European guidelines [8]. These results were used to categorize the cases, based on whether they supported the theory that regression in SLNs may be greater than in NSLNs or not (Table 1). The table reflects the nodes with the best/highest degree of regression for each case.

No patient identity related data were required or used, disease outcome was indifferent for the study purposes, and this retrospective non-interventional setting had no influence on treatment. Such a protocol does not imply an ethical approval in most of the participating institutions, but the Ethical Committee and Data Safety Manager of Bács-Kiskun County Teaching Hospital, where the study was initiated, were consulted and no ethical concerns were raised (Reference Number: 4/170125).

\section{Results}

The mean ( \pm S.D.) age of the patients was $50.2( \pm 11.0)$ years. A median of 2 SLNs (range: 1-8) and 14 nonSLNs (range: 2-42) were removed from the patients. The neoadjuvant treatment involved hormonal therapy with aromatase inhibitors in 10 cases, whereas the remaining patients received chemotherapies. There were 110 estrogen receptor (ER) positive tumors (including 25 human epidermal growth factor receptor 2 - HER2 positive cases), and of the 32 ER negative tumors, 12 were HER2 positive by immunohistochemistry or in situ hybridization. Complete primary tumor regression with or without residual in situ carcinoma was seen in 24 cases, and no signs of regression were reported in 16 primary cancers. No nodal regression at all was 
Table 1 Categorization of the results on the basis of possible variations in the distribution of metastases and regression and their relation to the theory of a possible selective regression pattern in SLNs

\begin{tabular}{|c|c|c|c|c|c|c|}
\hline $\mathrm{SN}$ metastasis & $\mathrm{SN}$ regression & NSN metastasis & NSN regression & Category & Relation to theory & No. of cases \\
\hline \multirow[t]{10}{*}{ Yes } & \multirow[t]{6}{*}{ Yes } & \multirow[t]{2}{*}{ No } & Yes & A & Against & 9 \\
\hline & & & No & $\mathrm{B}$ & Indifferent & 15 \\
\hline & & \multirow[t]{4}{*}{ Yes } & Yes $(=\mathrm{SN})$ & $\mathrm{CO}$ & Indifferent & 8 \\
\hline & & & Yes $(<\mathrm{SN})$ & $\mathrm{C} 1$ & In favor & 11 \\
\hline & & & Yes $(>\mathrm{SN})$ & $\mathrm{C} 2$ & Against & 5 \\
\hline & & & No & $\mathrm{D}$ & In favor & 6 \\
\hline & \multirow[t]{4}{*}{ No } & \multirow[t]{2}{*}{ No } & Yes & $\mathrm{E}$ & Against & 3 \\
\hline & & & No & $\mathrm{F}$ & Indifferent & 24 \\
\hline & & \multirow[t]{2}{*}{ Yes } & Yes & G & Against & 5 \\
\hline & & & No & $\mathrm{H}$ & Indifferent & 18 \\
\hline \multirow[t]{8}{*}{ No } & \multirow[t]{4}{*}{ Yes } & \multirow[t]{2}{*}{ No } & Yes & I & Indifferent & 11 \\
\hline & & & No & $\mathrm{J}$ & Indifferent & 2 \\
\hline & & \multirow[t]{2}{*}{ Yes } & Yes & $\mathrm{K}$ & In favor & 1 \\
\hline & & & No & $\mathrm{L}$ & In favor & 0 \\
\hline & \multirow[t]{4}{*}{ No } & \multirow[t]{2}{*}{ No } & Yes & M & False negative SLN & 7 \\
\hline & & & No & $\mathrm{N}$ & Indifferent & 9 \\
\hline & & \multirow[t]{2}{*}{ Yes } & Yes & $\mathrm{O}$ & False negative SLN & 6 \\
\hline & & & No & $\mathrm{P}$ & False negative SLN & 2 \\
\hline
\end{tabular}

evidenced in 19 node-positive cases, whereas 55 cases had at least one metastatic lymph node without evidence of regression (NR4). The metastasis and regression status of the analyzed cases are summarized in Table 1.

Categories B, C0, F, H, I, J and N represented 87/142 cases including 40 node-positive cases without evidence of regression in the lymph nodes (Table 1), and were indifferent towards the tested hypothesis. Of the 89 cases with signs of nodal regression, the 22 cases in categories $\mathrm{A}, \mathrm{C} 2, \mathrm{E}$ and $\mathrm{G}$, where the regression was of greater degree in non-SLNs (22/ 89 cases, $25 \%$ ) were in favor of a selective non-regression in SLNs. Only 18/89 cases (20\%) fell into categories C1, D or K, and were in support of a selective and more pronounced regression in the SLNs.

\section{Discussion}

The practice of SLN biopsy in locally advanced breast cancer patients receiving neoadjuvant systemic treatment is still somewhat controversial. Often the SLN biopsy was performed before primary systemic therapy or was not performed because of previously evidenced metastatic lymph nodes. The required cases were relatively rare in our archives, and the present study should be regarded as an exploration of the theory of a potential selective regression (or non-regression) in SLNs.
There are some reservations regarding the possible conclusion of the study. The methods of SLN biopsy were obviously not uniform, but were the ones applied and relied on in clinical practice at the given institution. The nature of the therapeutic agents used for primary systemic treatment could not be taken into account, as there was a wide variation in the protocols and drugs used, and the low case numbers would not have made any treatment-specific analysis possible. Altogether the case numbers are relatively small, however, the distribution of the cases did not point in favor or against a selective regression (or non-regression) in SLNs. Finally, fibrotic foci in the lymph nodes were interpreted as signs of regression, but these signs are not specific, and other processes may lead to the same morphological features. However, in the setting of neoadjuvant therapy, this latter is the most likely cause for these morphological changes, and therefore these were uniformly interpreted as signs of regression.

The evidence gathered from the limited number of cases available suggests that despite the attractiveness of a preferential regression (or non-regression) in tumor draining lymph nodes (SLNs which seem to be immunosuppressed and at the same time are the sites of TRL), there is no obvious difference in the degree of regressive histological changes shown by SLNs and NSLNs. Therefore, this phenomenon may not be a major contributor to the somewhat higher false negative rate of SLN biopsy after neoadjuvant treatment [9]. 
Acknowledgements The study was supported by the National Research, Development and Innovation Office grant GINOP-2.3.2-152016-00020. The content of the communications has not been influenced by this support.

\section{References}

1. Greenall MJ (1995) Why I favour axillary node sampling in the management of breast cancer. Eur J Surg Oncol 21:2-5

2. Cserni G (1999) Estimating the overlap between sentinel lymph nodes and axillary node samples in breast cancer. Pathol Oncol Res 5:129-133

3. Qian CN, Berghuis B, Tsarfaty G, Bruch M, Kort EJ, Ditlev J, Tsarfaty I, Hudson E, Jackson DG, Petillo D, Chen J, Resau JH, Teh BT (2006) Preparing the "soil": the primary tumor induces vasculature reorganization in the sentinel lymph node before the arrival of metastatic cancer cells. Cancer Res 66:10365-10376

4. Schüle JM, Bergkvist L, Håkansson L, Gustafsson B, Håkansson A (2004) CD28 expression in sentinel node biopsies from breast cancer patients in comparison with CD3-zeta chain expression. J Transl Med 2:45. doi:10.1186/1479-5876-2-45

5. Schüle J, Bergkvist L, Håkansson L, Gustafsson B, Håkansson A (2002) Down-regulation of the CD3-zeta chain in sentinel node biopsies from breast cancer patients. Breast Cancer Res Treat 74:33-40

6. Cochran AJ, Huang RR, Lee J, Ikatura E, Leong SP, Essner R (2006) Tumour-induced immune modulation of sentinel lymph nodes. Nat Rev Immunol 6:659-670

7. Straver ME, Loo CE, Alderliesten T, Rutgers EJ, Vrancken Peeters MT (2010) Marking the axilla with radioactive iodine seeds (MARI procedure) may reduce the need for axillary dissection after neoadjuvant chemotherapy for breast cancer. Br J Surg 97:1226-1231

8. Wells CA, Amendoeira I, Bellocq JP et al (2012) S2: pathology update. Quality assurance guidelines for pathology. In: Perry N, Broeders $\mathrm{M}$, de Wolf $\mathrm{C}$ et al (eds) European guidelines for quality assurance in breast cancer screening and diagnosis, 4th edn, supplements. European Commission, Office for Official Publications of the European Union, Luxembourg, pp 73-120

9. Mocellin S, Goldin E, Marchet A, Nitti D (2016) Sentinel node biopsy performance after neoadjuvant chemotherapy in locally advanced breast cancer: a systematic review and meta-analysis. Int $\mathrm{J}$ Cancer 138:472-480 
III. Zombori T, Cserni G. Elastic stains in the evaluation of DCIS with comedo necrosis in breast cancers. Virchows Arch. 2018;472:1007-1014. doi: 10.1007/s00428-017-2259-z.

IF: 2.93 


\title{
Elastic stains in the evaluation of DCIS with comedo necrosis in breast cancers
}

\author{
Tamás Zombori ${ }^{1}$ - Gábor Cserni ${ }^{1,2}$ (i)
}

Received: 17 September 2017 /Revised: 9 October 2017 / Accepted: 23 October 2017 /Published online: 3 November 2017

(C) Springer-Verlag GmbH Deutschland 2017

\begin{abstract}
As concerns the microscopic morphology of ductal carcinoma in situ (DCIS), neoplastic cells are surrounded by both a myoepithelial cell layer and a basement membrane as expected from the outer structure of ducts and lobules. However, in some cases, it is impossible to state whether the structures involved by the disease are ducts or lobules. Altogether 1220 anatomic structures involved by DCIS displaying comedo necrosis from 27 slides of 21 patients (seen on both haematoxylin and eosin-stained and orcein-stained slides) were identified as representing ducts, likely ducts, unclassifiable structures, likely acini or acini on the basis of their distribution and resemblance to normal anatomic structures. All structures were then rated as having a circumferential elastic layer (as normal ducts), a partial elastic layer around more or less than half of the periphery or having no peripheral elastic layer at all (as normal acini). Structures classified as ducts or likely ducts were likely to have an elastic coating, whereas acini and likely acini had no such coating. Unclassifiable structures were generally devoid of an elastic layer. Structures (and cases) that were likely to represent neoductgenesis as proposed by Zhou et al. (Int J Breast Cancer 2014;2014:581706) were generally unclassifiable and devoid of outer elastic layer. Many duct-like structures in DCIS with comedo necrosis are devoid of elastic layer typical of normal ducts, suggesting that these structures are
\end{abstract}

Gábor Cserni

cserni@freemail.hu

1 Department of Pathology, Albert Szent-Györgyi Medical Centre, University of Szeged, Állomás u. 1., 6720 Szeged, Hungary

2 Department of Pathology, Bács-Kiskun County Teaching Hospital, Nyiri ut 38., 6000 Kecskemét, Hungary abnormal despite conservation of the myoepithelium and the basement membrane.

Keywords Breast cancer $\cdot$ Comedo necrosis $\cdot$ Ductal carcinoma in situ $\cdot$ Elastic stain $\cdot$ Neoductgenesis

\section{Introduction}

Breast parenchyma is organised into anatomic units corresponding to mammary lobes. A lobe can be defined as the complex of a lactiferous duct branching into smaller and smaller ducts with terminal ductules and the lobule forming acini belonging to these ductules at the end, i.e. each lactiferous duct defines a different lobe, of which 15 to 25 make up the breast parenchyma [1]. An easy to imagine visual analogy of the lobar organisation would be that of a tree, where the lactiferous duct would correspond to the trunk, the ducts to branches and the lobules to compound leaves. The outer myoepithelial layer and the basement membrane around the ducts would represent the bark of the tree. Acini of the lobules and ducts are easy to distinguish from each other. However, when their lumen enlarges and the diameter becomes larger, ectatic ducts and cystically dilated acini are not always easy to separate. The maintained lobular architecture, multiplicity of the lumens and the common presence of apocrine epithelium helps to identify dilated lumina as cysts. In contrast to cysts, ectatic ducts are generally single or separated from each other by normal breast adipose or fibrous tissue more in keeping with interlobular stroma than with intralobular stroma. Although both the ducts and lobules feature an outer myoepithelial cell layer and a basement membrane, there is usually also an elastic layer around the ducts, which is missing around the acini (Fig. 1). This phenomenon can also help in the distinction between ectatic ducts or cystic acini, although 


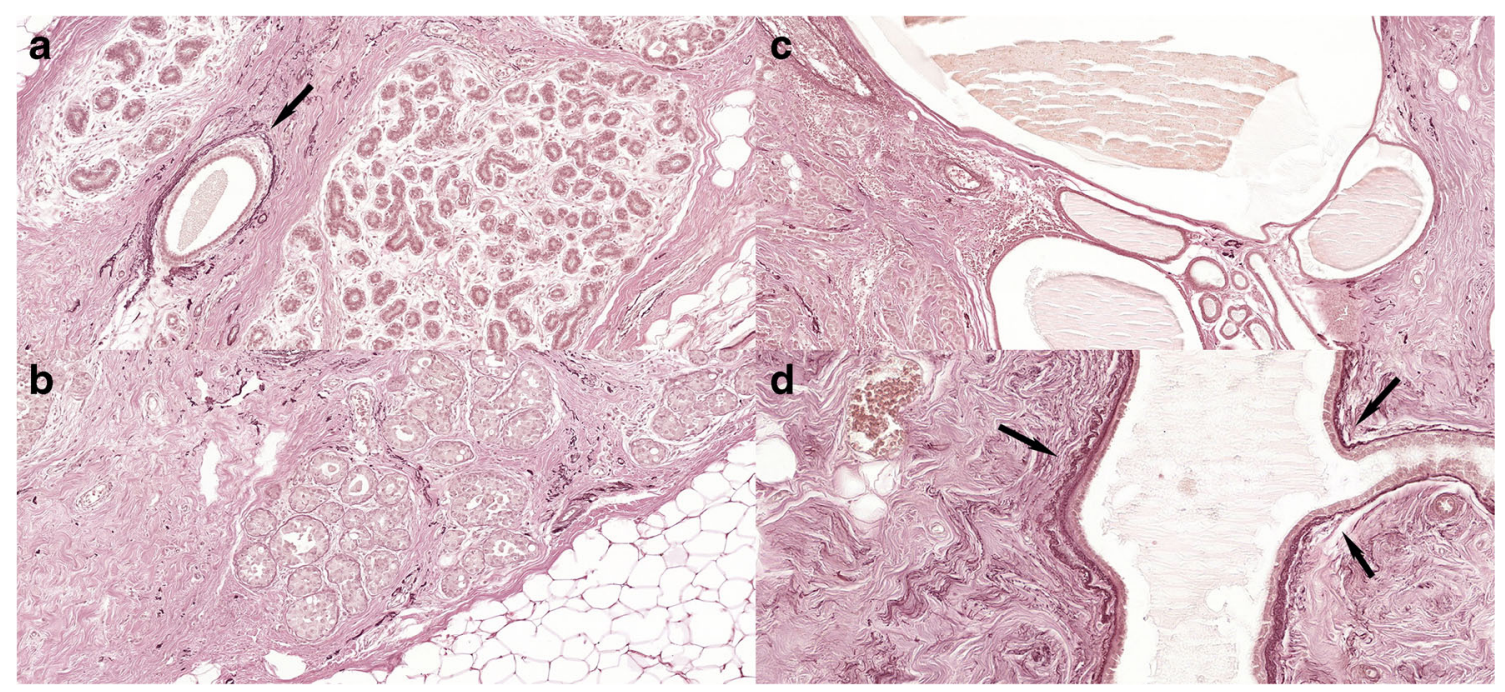

Fig. 1 Elastic fibres around normal and dilated anatomic structures. a A duct with elastic coating (arrow) and acini without an outer elastic layer arranged into lobules. b Lobular cancerisation. DCIS extending into a lobule without altering the lack of elastic fibres around lobule forming acini. c Closely packed cysts devoid of elastic fibres. $\mathbf{d}$ Ectatic duct with maintained elastic coating (arrows). (Orcein, $\times 10, \times 10, \times 8, \times 15$ ) the amount of elastic fibres around dilated ducts is dependent on the amount initially present and any damage by inflammatory processes (Fig. 1) [2].

When ductal carcinoma in situ (DCIS) develops in the ductal tree or its end, the terminal ductulolobular unit (TDLU), there is often a dilatation of the normal anatomic structures. When the anatomy of the breast is maintained, DCIS can easily be identified as involving the ducts and sometimes the lobules. The latter phenomenon has been called cancerisation of lobules or lobular cancerisation [3, 4] (Fig. 1b). The analogy of the tree also applies to this presentation.

Some forms of DCIS do not follow this regular growth and intraluminal spread. Instead, there are plenty of more or less dilated lumens dispersed with a relatively uniform and higher than normal density. Although some believe that this pattern is also due to abnormal extent of dilatation of preexisting structures (i.e. ducts and lobules) like overinflated balloons touching each other, there is apparently no obviously discernible lobular architecture maintained. The concept of neoductgenesis has been introduced to explain the morphology of these cancers $[5,6]$. This concept suggests that new ducts are formed from the preexisting ones and grow into the stroma. Keeping the analogy of the tree, this would correspond to new lateral branches starting to grow from the trunk or other larger branches, keeping the characteristic feature of branches, i.e. having their bark. Indeed, the structures identified under the microscope in such cases have a myoepithelial layer and a basement membrane and are easy to interpret as DCIS, although myoepithelial phenotype and myoepithelial marker expression may be altered [7, 8]. Newly formed ducts 'invade' the stroma in a pushing manner without losing their myoepithelial and basement membrane layers which are the diagnostic hallmark of in situ carcinomas and the clue used to exclude the presence of invasion in breast pathology. This controversy is certainly the cause why the concept of neoductgenesis is not widely accepted, despite having more and more advocates. Neoductgenesis could explain the aggressive behaviour of tumours with this phenomenon having minor areas of classical invasive carcinoma of no special type (interpreted as ductal carcinomas with extensive intraductal component). Such tumours have a larger whole tumour size (including the DCIS morphology) than invasive tumour size (including only the smaller classical invasive carcinoma), and when stratified according to other prognosticators, their survival curves match those of no special type invasive tumours of which the size corresponds to the whole tumour size of tumours with neoductgenesis rather than their classical invasive tumour size $[5,6]$. The phenomenon could also be an explanation for the anecdotal cases where no classical invasive tumour is identified near DCIS with features of neoductgenesis, but the patient dies of breast cancer [6]. Local recurrence rates in cases diagnosed as representing pure DCIS are also higher in neoplasms with proposed neoductgenesis, and this is also related to their greater extension and diffuse growth pattern [9, 10] but also reflects a worse overall prognosis.

Neoductgenesis is not easy to define. It has been associated with casting (linear branching) type calcifications on the mammogram, and tumours with this manifestation have been reported to have poor outcome in several series [5, 11-14] with some contradicting results in others [15-17]. Tenascin expression has been demonstrated around the newly formed ducts $[5,6]$. Morphologic criteria have also been proposed on the basis of duct concentration, periductal fibrosis and lymphocytic infiltration [18] and may help to identify cases with this phenomenon even on histological slides. 


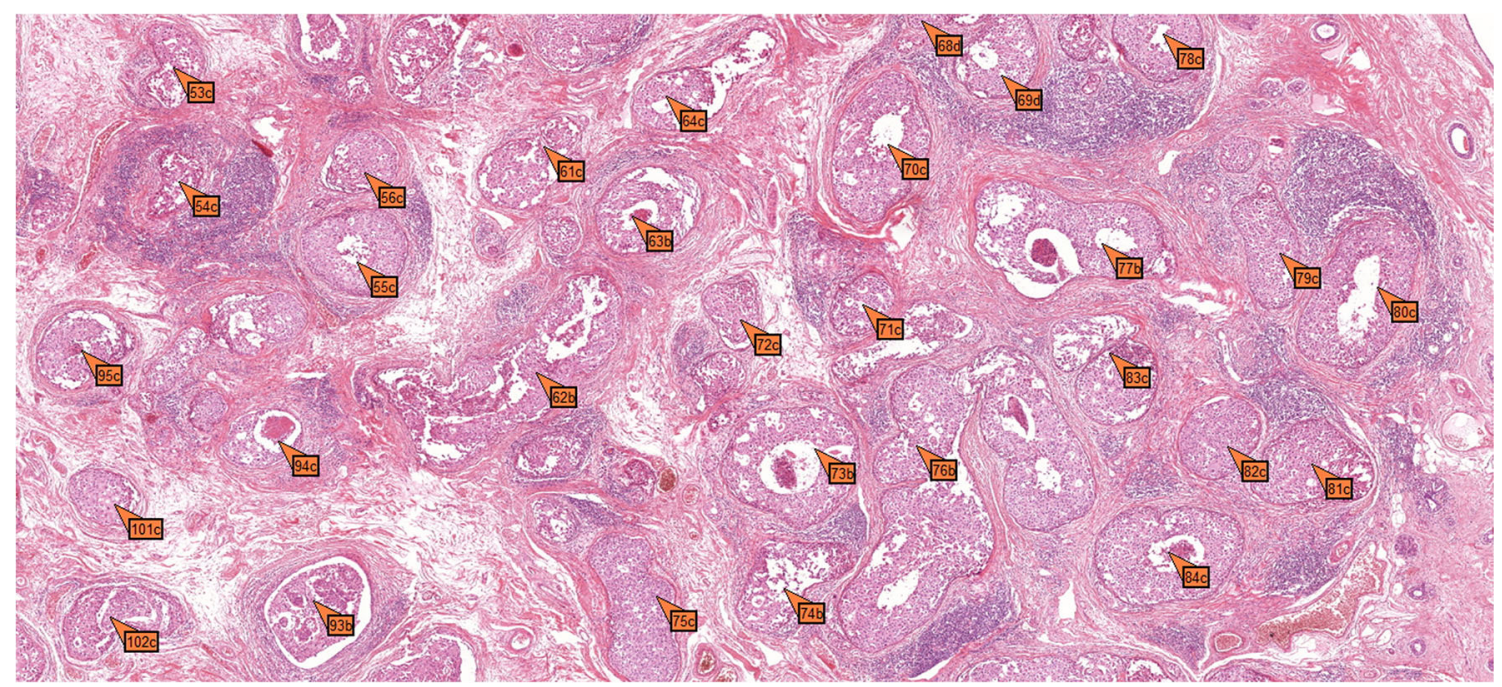

Fig. 2 Annotated structures. Structures that could be identified on both HE and ORC slides were numbered and classified as ducts (a), likely ducts (b), unclassifiable structures (c), likely acini (d) or acini (e)

In the present study, we analysed lumen forming structures of the DCIS component of a few tumours (some of which were believed to represent DCIS with neoductgenesis) with orcein staining with the aim to see how ducts and acini maintain their staining when involved by DCIS and to see how ducts believed to be newly formed behave with this stain.

\section{Material and methods}

Selected histological slides of patients with areas of DCIS (mostly associated with areas of invasive cancer) demonstrating comedo necrosis and central, amorphous microcalcification on histology slides were retrospectively analysed. The study cases were from the Pathology Departments of the University of Szeged (collected from a consecutive series of patients with radiologic evidence of casting (linear branching) type calcification) and the Bács-Kiskun County Teaching Hospital (randomly selected cases with comedo necrosis and central amorphous calcification in the slides; these were from a previous pilot study looking at the elastic stains).The clinicopathological information needed was obtained from the radiological and histopathological reports.

Inclusion criteria were the following: casting (linear branching) type calcification described by the radiological report or the histopathology report, high or intermediate grade DCIS [19] with or without invasive breast carcinoma, resected tumour specimens and availability of slides and paraffin blocks. For control, two slides with normal breast tissue and architecture (derived from non-tumorous random samples of resections performed for breast cancer) were included in the study.
Haematoxylin and eosin (HE) staining was employed for the identification of anatomic structures involved by the in situ neoplastic cells as ducts or acini, whereas orcein staining alone or combined with haematoxylin or HE (ORC) was used for the evaluation of elastic fibres around the units previously classified on the basis of the HE stain. One or two slides per case were selected and digitised with a 3DHistec Pannoramic 250 Flash III scanner.

In the first step, with the aid of the freely downloadable Pannoramic Viewer software (3DHistec, Budapest, Hungary), the structures were numbered in parallel on both the HE and the ORC digital slides (Fig. 2).

Each numbered structure that could be identified on both HE and ORC stained slides was then classified into one of the following categories: definitely representing a duct, likely to be a duct, unclassifiable, likely to be an acinus, and definitely representing an acinus (Fig. 2). For this classification, the resemblance to the normal microanatomical structures was considered, i.e. clustered arrangement into or resemblance to lobular structures pointing to acinar structures and single structures pointing to a ductal nature.

The elastic fibres around the numbered and classified structures were graded as concentric presence (score 3), dominant presence (continuous or discontinuous elastic fibres around more than half of the perimeter of the structure; score 2), dominant absence (focal, elastic fibres around less than half of the perimeter of the structure; score 1) and absence of elastic fibres around the structure (score 0) (Fig. 3).

The neoductgenesis score described by Zhou et al. [18] was applied for the identification of tumours demonstrating neoductgenesis. (The cases were selected before this description was read). This scoring system takes into account the concentration of duct-like structures and loss of normal ductal-lobular architecture, the lymphocytic 


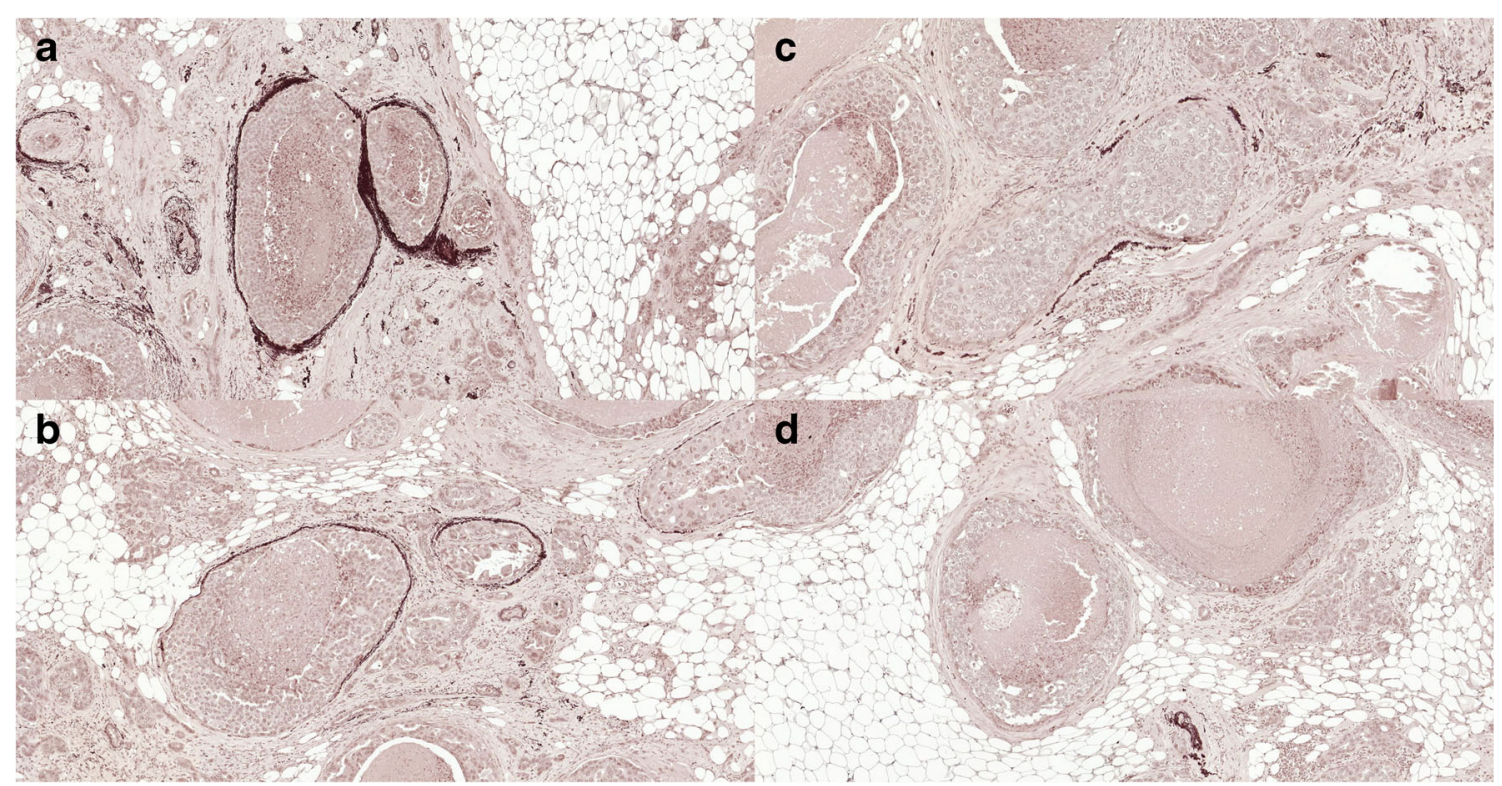

Fig. 3 Scoring of the elastic layer around anatomical structures. a Concentric presence (score 3). b Dominant presence (continuous or discontinuous elastic fibres around more than half of the perimeter of

infiltration and periductal fibrosis (Table 1). The original description of the score also includes a visual scale for each score component, and this was used to label the cases. However, we also applied the score to individual structures. For this, we used the first component of the combined score from the entire slide, but the two remaining score components were derived from the lymphocytic infiltration and fibrosis around the given structure.

Table 1 Neoductgenesis score [18]

\begin{tabular}{ll}
\hline Variable & Score \\
\hline $\begin{array}{l}\text { Concentration of duct-like structures } \\
\text { and loss of normal ductal-lobular }\end{array}$ & \\
architecture & \\
Absent & 0 \\
Focal & 1 \\
General & 2 \\
Periductal lymphocytic infiltration & \\
Absent & 0 \\
Mild & 1 \\
Pronounced & 2 \\
Periductal fibrosis & \\
Absent & 0 \\
Mild & 1 \\
Pronounced & 2 \\
Neoductgenesis & Score \\
Present & $5-6$ \\
Absent & $0-4$ \\
\hline
\end{tabular}

the structure; score 2). c Dominant absence (focal, elastic fibres around less than half of the perimeter of the structure; score 1). d Complete or nearly complete absence of elastic fibres around the structure (score 0 )

The statistics included the Mann-Whitney and the chisquare tests. All statistical tests were two-sided, and $p<0.05$ values were considered statistically significant.

The institutional ethical committee of the Bács-Kiskun County Teaching Hospital was consulted and raised no concerns about this non-interventional retrospective study.

\section{Results}

Twenty-seven slides from 21 female patients were investigated in this retrospective study (median 1 slide/case). The mean age of the patients was 63.7 (range 46-86). The basic clinicopathological parameters are displayed in Table 2. Two thirds of the patients had high grade DCIS with invasive carcinoma of no special type. The mean \pm S.D. invasive tumour size and tumour extension (including DCIS as well) were $13.9 \pm 17.7 \mathrm{~mm}$ (range $=0$ $65 \mathrm{~mm}$ ) and $44.4 \pm 30.7 \mathrm{~mm}$ (range $=12-65 \mathrm{~mm}$ ), respectively. The invasive component showed almost exclusively high nuclear grade. The in situ component was of high grade in all but one case. Oestrogen receptor and progesterone receptor positivity were observed in 13 cases and 11 cases, respectively. Intense, concentric membranous positivity of human epidermal growth factor receptor-2 (HER-2) was seen in 13 cases (61.9\%). Centrally calcified comedo type necrosis was present in all cases, and casting (linear branching) type calcification on the mammogram was documented in 17 cases; two cases had mammography elsewhere and no data on the type of calcifications were available, and two cases had 
Table 2 Basic clinicopathological information in the cases studied

Specimen

\begin{tabular}{ll}
\hline Mastectomy & $9(42.8 \%)$ \\
Breast-conserving surgery & $12(57.2 \%)$ \\
Histological diagnosis & \\
Pure DCIS & $9(42.8 \%)$ \\
DCIS with invasive carcinoma & $12(57.2 \%)$ \\
Oestrogen receptor & \\
Positive & $13(61.9 \%)$ \\
Negative & $8(38.1 \%)$ \\
Progesterone receptor & \\
Positive & $11(52.3 \%)$ \\
Negative & $10(47.7 \%)$ \\
HER-2 & \\
$3+$ & $11(52.3 \%)$ \\
$2+$ & $1(4.8 \%)$ \\
$1+$ & $1(4.8 \%)$ \\
Negative & $8(38.1 \%)$ \\
\hline
\end{tabular}

DCIS ductal carcinoma in situ, HER-2 human epidermal growth factor receptor-2

granular rather than casting type calcification described in the radiological report.

Altogether 1220 structures were classified as ducts or acini with different levels of certitude, as described in the 'Material and methods'. The majority (nearly two thirds) were unclassifiable, and between 7.4 and $13.6 \%$ belonged to one of the four remaining categories each. The relation of these classified structures to peristructural elastic fibres is shown in Table 3. The concentric presence of elastic fibres is more frequent around structures identified as ducts or likely ducts but was also seen around a minority of unclassifiable structures. At the opposite end of the spectrum, acini lack elastic fibres around, similarly to likely acini. Most unclassifiable structures are also completely or partially (dominant absence pattern) devoid of peristructural elastic fibres (Fig. 4).

Ducts $(n=33)$ and acini $(n=150)$ of control breast slides were also analysed for the presence of elastic coating around these normal structures. The Mann-Whitney test revealed significant difference between ducts and acini: a concentric elastic fibre layer surrounds almost all normal ducts, but the acini do not have such an elastic coating $(p<0.001)$.

Neoductgenesis was identified in six $(25.5 \%)$ cases by using the neoductgenesis score suggested by Zhou and coworkers. After the application of this scoring system to all numbered structures, we found that in neoductgenesis positive tumours, $27.3 \%$ of the numbered units were suggested as neoducts and there was hardly any potential neoducts $(0.75 \%)$ in neoductgenesis negative tumours.

We examined the means of the scores of numbered individual structures per case, as well. In neoductgenesis positive tumours $(n=6)$, the average of the neoductgenesis-related scores was higher $($ mean \pm S.D. $=3.87 \pm 0.35$, range $=3.49-4.39)$ than in neoductgenesis negative cases (mean \pm S.D. $=1.97 \pm 1.11$, range $=0-3.1$ )

Two third of these neoducts identified by the per structure scoring system are irregular and uncertainly classifiable structures (Table 4) and almost $80 \%$ of them are not or dominantly not surrounded by elastic fibres. The chisquare test revealed a significant difference between the normal structures and the individual score based neoducts: the latter generally do not have an elastic layer around $(p<0.001)$.

In neoductgenesis positive and negative tumours, the presence of elastic fibres was evaluated by scoring of each structure on orcein-stained slides as described in the 'Material and methods'. Lower scores were found in the neoductgenesis positive tumours (mean \pm S.D. $=0.57 \pm 0.32$, range $=0.28$ $0.91)$ than in neoductgenesis negative neoplasms (mean \pm S.D. $=0.89 \pm 0.54$, range $=0.1-2.1$ ).
Table 3 The proportions of elastic fibres around the evaluated structures

\begin{tabular}{|c|c|c|c|c|c|c|c|c|c|c|}
\hline \multirow[t]{3}{*}{ Duct vs. acinus } & \multicolumn{8}{|c|}{ Elastic fibres } & \multirow[t]{3}{*}{ All $(n)$} & \multirow[t]{3}{*}{ All (\%) } \\
\hline & \multicolumn{2}{|c|}{ Absence } & \multicolumn{2}{|c|}{$\begin{array}{l}\text { Dominant } \\
\text { absence }\end{array}$} & \multicolumn{2}{|c|}{$\begin{array}{l}\text { Dominant } \\
\text { presence }\end{array}$} & \multicolumn{2}{|c|}{$\begin{array}{l}\text { Concentric } \\
\text { presence }\end{array}$} & & \\
\hline & $n$ & $\%$ & $n$ & $\%$ & $n$ & $\%$ & $n$ & $\%$ & & \\
\hline Duct & 5 & 0.4 & 9 & 0.7 & 24 & 1.9 & 53 & 4.4 & 91 & 7.4 \\
\hline Likely duct & 21 & 1.3 & 34 & 2.9 & 25 & 2 & 33 & 2.7 & 113 & 8.9 \\
\hline Unclassifiable & 559 & 45.9 & 142 & 11.7 & 36 & 3.1 & 25 & 2 & 762 & 62.7 \\
\hline Likely acinus & 88 & 7.3 & 1 & 0.07 & 1 & 0.07 & 0 & 0 & 90 & 7.44 \\
\hline Acinus & 162 & 13.4 & 2 & 0.16 & 0 & 0 & 0 & 0 & 164 & 13.56 \\
\hline All & 835 & 68.3 & 188 & 15.53 & 86 & 7.07 & 111 & 9.1 & 1220 & 100 \\
\hline
\end{tabular}


Fig. 4 Elastic fibres around ducts involved by DCIS, and their absence around similar structures, that could represent neoducts but do not reach an individual score for the qualification as neoduct in a neoductgenesis negative case on the basis of the overall score (Orcein, $\times 4$ ). Note the branching of the elastic fibre-negative structure from the elastic fibrepositive duct

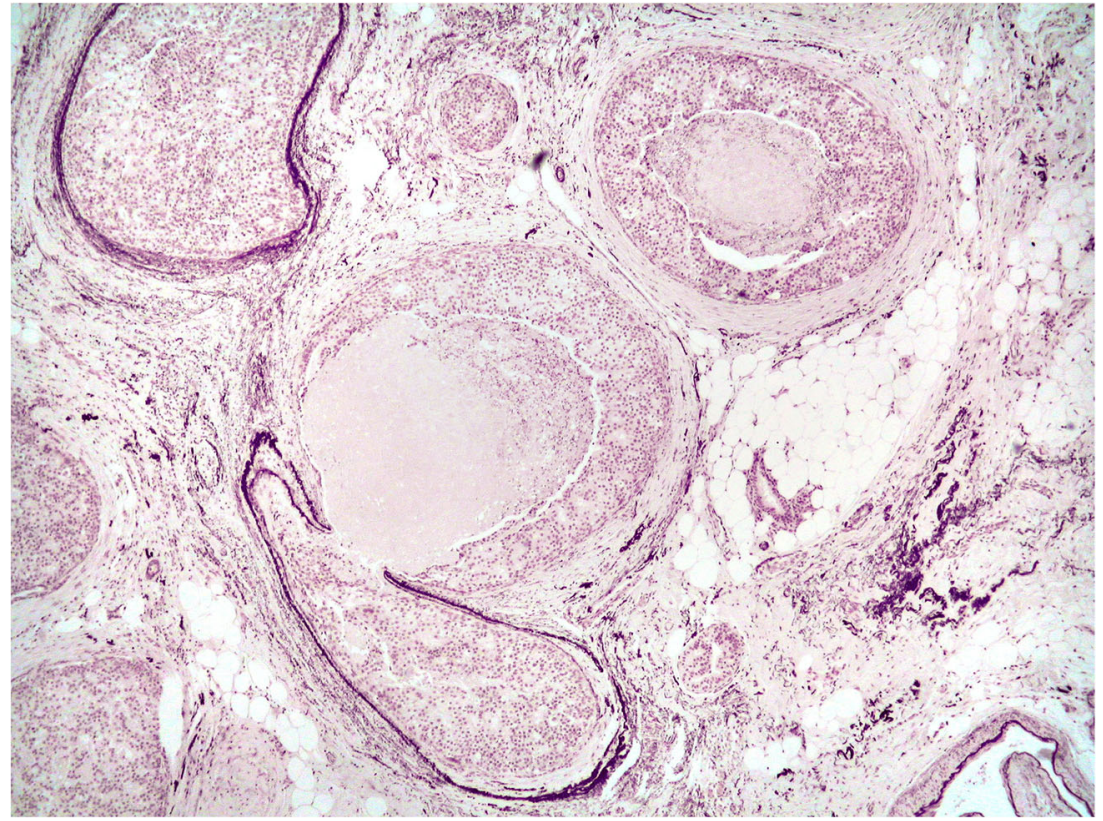

\section{Discussion}

Our study of a large number of breast microanatomic structures suggests that most of the densely packed structures involved by morphological DCIS with comedo necrosis cannot be classified on the basis of the HE look as ducts or acini. The study of the control cases reinforced the known microanatomy of ducts and lobules, of which only the previous have an elastic coating. The study also demonstrated that DCIS involved structures that could be classified as ducts or acini with some certainty displayed the elastic coating expected on the basis of the normal anatomic structures. On the other hand, most structures that could not be reliably classified as ducts or acini, in parallel with most structures classified as representing neoducts on the basis of the proposed scoring system [18] adapted to the individual structures, were devoid of an elastic coating. Although this could be used as a support to the acinar origin of these structures, it is more realistic to suggest that together with previously described stromal periductal tenascin- $\mathrm{C}$ accumulation $[5,6]$, this could be another difference between preexisting and newly formed ducts. It is not known whether the proposed new ducts are devoid of periductal elastic fibres from the beginning or these fibres are lost as a consequence of periductal inflammation and/or fibrosis.

Myoepithelial cells have been reported to have an altered phenotype in some DCIS cases, characterised by the loss of one or more myoepithelial markers labelling the myoepithelium around normal anatomic mammary structures. The phenomenon occurs more frequently in high grade DCIS. None of the present cases were of low grade, and all but one case were of high grade. Although we did not study the expression of myoepithelial markers, we detected another
Table 4 The morphological characteristics of potential neoducts $(n=218)$

\begin{tabular}{|c|c|c|c|c|c|c|c|c|c|c|}
\hline \multirow[t]{3}{*}{ Neoduct } & \multicolumn{8}{|c|}{ Elastic fibres } & \multirow{3}{*}{$\begin{array}{l}\text { All } \\
(n)\end{array}$} & \multirow{3}{*}{$\begin{array}{l}\text { All } \\
(\%)\end{array}$} \\
\hline & \multicolumn{2}{|c|}{ Absence } & \multicolumn{2}{|c|}{$\begin{array}{l}\text { Dominant } \\
\text { abscense }\end{array}$} & \multicolumn{2}{|c|}{$\begin{array}{l}\text { Dominant } \\
\text { presence }\end{array}$} & \multicolumn{2}{|c|}{$\begin{array}{l}\text { Concentric } \\
\text { presence }\end{array}$} & & \\
\hline & $n$ & $\%$ & $n$ & $\%$ & $n$ & $\%$ & $n$ & $\%$ & & \\
\hline Duct & 3 & 1.4 & 5 & 2.4 & 5 & 2.4 & 15 & 6.9 & 28 & 13.1 \\
\hline Likely duct & 5 & 2.4 & 13 & 6.2 & 9 & 4.2 & 5 & 2.4 & 32 & 15.2 \\
\hline Unclassified & 109 & 50 & 20 & 9.3 & 5 & 2.4 & 5 & 2.4 & 139 & 64.1 \\
\hline $\begin{array}{l}\text { Likely } \\
\text { acinus }\end{array}$ & 8 & 3.7 & 1 & 0.6 & 0 & 0 & 0 & 0 & 9 & 4.3 \\
\hline Acinus & 7 & 3.3 & 0 & 0 & 0 & 0 & 0 & 0 & 7 & 3.3 \\
\hline All & 132 & 60.8 & 39 & 18.5 & 19 & 9 & 28 & 11.7 & 218 & 100 \\
\hline
\end{tabular}


abnormality of high grade DCIS cases with comedo necrosis, namely the lack of elastic fibres around the ducts. This was not only present in cases which displayed a neoductgenesis score above 4 but also in cases with lower scores.

Neoductgenesis is a concept to explain the morphology of certain breast cancers that show neoplastic cells in densely packed anatomic structures seemingly corresponding to either normal ducts or acini on the basis of the presence of a basement membrane and a myoepithelial layer at the outer surface but not corresponding to any of these preexisting structures when looking at the lack of the tree-like distribution of normal anatomic structures described in the 'Introduction'. The theory suggests that some breast carcinomas are characterised by the outgrowth of new branches, i.e. new ducts, neoducts from the ductal tree, representing a pushing type infiltration. Densely packed, tumour involved, myoepithelium coated structures could theoretically represent engulfed preexisting acini (and ducts), but when one looks at the phenomenon of lobular cancerization, where this neoplastic inflation happens, or at ductectasia or cystic changes where dilation of preexisting lumina generally occurs without intraluminal epithelial proliferation, it is clear that these processes maintaining the tree-like structure are different from cancers with presumed neoductgenesis. Three-dimensional analysis of such cases further reinforces the lack of normal distribution of ducts and acini in such tumours [6]. This 'disturbed arborisation' [9, 10] could be the result of a disturbed alveolar switch [20], a hormonally driven physiologic mechanism responsible for the development of acini from ductal epithelium. Our report indicates that the proposed neoducts are also devoid of elastic coating, resembling acini in this respect.

There were more structures that could not be reliably classified as ducts or acini than structures corresponding to neoducts on the basis of the neoduct scoring applied to the individual structures. These unclassifiable structures were generally devoid of elastic fibres. Cases that could not be classified as representing neoductgenesis on the basis of the overall score also contained such elastic fibreless unclassifiable structures. It could happen that more of these comedo necrotic structures correspond to neoducts than those identified as neoducts on the basis of the individually (per structure) applied score. Of the two other possible explanations, namely that the unclassifiable structures correspond to acini (originally lacking elastic fibres) or ducts losing their elastic coating, the first seems unlikely due to the diffuse and non-lobular distribution of these structures (this is why they could not be classified even as likely acini), whereas the second is also questionable on the basis of the distribution (there are too many of them clustered close to each other, not allowing their classification even as likely ducts).

Our study therefore identifies possible neoducts as structures devoid of elastic periductal fibres and most of the structures that could not be classified as (likely) ducts or (likely) acini on the basis of distribution patterns as similarly devoid of elastic fibres and possibly also as neoducts. The use of elastic stains may probably be an aid in the study of neoductgenesis.

Acknowledgments This study was partially funded by the National Research, Development and Innovation Office grant GINOP-2.3.2-152016-00020.

Author contribution All authors of the manuscript made substantial contributions to the conception or design of the work; the acquisition, analysis, or interpretation of data for the work; drafting the work and/or revising it critically for important intellectual content; final approval of the version submitted for publication; and agreement to be accountable for all aspects of the work in ensuring that questions related to the accuracy or integrity of any part of the work are appropriately investigated and resolved.

More specifically, author contribution is listed as follows:

TZ: Case selection, application and refinement of the methods, analysis of data, preparation of the manuscript, finalisation and approval of the manuscript

GC: Concept, development of the methods, case selection, supervision, preparation of the manuscript, finalisation and approval of the manuscript

\section{Compliance with ethical standards}

Ethics approval and consent to participate The authors have consulted the journal policy regarding compliance with ethical standards and state that accepted principles of ethical and professional conduct have been followed. The authors include information regarding sources of funding (see Acknowledgment) and potential conflicts of interest (financial or non-financial) (next section). The Institutional Ethical Committee of the Bács-Kiskun County Teaching Hospital was consulted, and no approval was deemed necessary for this retrospective analysis of histological slides requiring no patient identity-related information. An informed consent was not considered possible owing to the anonymity of the tissue sections used for evaluation. The study did not include animals; therefore, issues relating to animal welfare do not apply.

Conflict of interest The authors declare that they have no conflict of interest.

\section{References}

1. Tot T (2014) Normal breast tissue or fibrocystic change? In: Tot T, Tabár L, Dean PB (eds) Practical breast pathology, 2nd edn. Thieme, Stuttgart, pp 1-23

2. Azzopardi JG (1979) Cystic disease: duct ectasia: fat necrosis: 'fibrous disease of the breast'. In: Azzopardi JG (ed) Problems in breast pathology. Saunders, London, pp 57-91

3. Fechner RE (1971) Ductal carcinoma involving the lobule of the breast. A source of confusion with lobular carcinoma in situ. Cancer 28:274-281

4. Kerner H, Lichtig C (1986) Lobular cancerization: incidence and differential diagnosis with lobular carcinoma in situ of breast. Histopathology 10:621-629

5. Tabár L, Chen HHT, Yen MFA et al (2004) Mammographic tumor features can predict long-term outcomes reliably in women with 114-mm invasive breast carcinoma. Cancer 101:1745-1759

6. Tabár L, Tot T, Dean P (2007) Casting type calcifications: sign of a subtype with deceptive features. Thieme, Stuttgart 
7. Hilson JB, Schnitt SJ, Collins LC (2009) Phenotypic alterations in ductal carcinoma in situ-associated myoepithelial cells: biologic and diagnostic implications. Am J Surg Pathol 33:227-232

8. Kővári B, Szász AM, Kulka J et al (2015) Evaluation of p40 as a myoepithelial marker in different breast lesions. Pathobiology 82: $165-170$

9. Tot T, Tabár L (2005) Mammographic-pathologic correlation of ductal carcinoma in situ of the breast using two- and threedimensional large histologic sections. Semin Breast Dis 8:144-151

10. Tot T (2005) DCIS, cytokeratins, and the theory of the sick lobe. Virchows Arch 447:1-8

11. Tabár L, Chen HH, Duffy SW et al (2000) A novel method for prediction of long-term outcome of women with $\mathrm{T} 1 \mathrm{a}, \mathrm{T} 1 \mathrm{~b}$, and 10-14 mm invasive breast cancers: a prospective study. Lancet 355:429-433

12. Zunzunegui RG, Chung MA, Oruwari J, Golding D, Marchant DJ, Cady B (2003) Casting-type calcifications with invasion and highgrade ductal carcinoma in situ: a more aggressive disease? Arch Surg 138:537-540

13. Pálka I, Ormándi K, Gaál S, Boda K, Kahán Z (2007) Casting-type calcifications on the mammogram suggest a higher probability of early relapse and death among high-risk breast cancer patients. Acta Oncol 46:1178-1183

14. Bennett RL, Evans AJ, Kutt E et al (2011) Pathological and mammographic prognostic factors for screen detected cancers in a multicentre randomised, controlled trial of mammographic screening in women from age 40 to 48 years. Breast 20:525-528
15. James JJ, Evans AJ, Pinder SE, Macmillan RD, Wilson AR, Ellis IO (2003) Is the presence of mammographic comedo calcification really a prognostic factor for small screen-detected invasive breast cancers? Clin Radiol 58:54-62

16. Månsson E, Bergkvist L, Christenson G, Persson C, Wärnberg F (2009) Mammographic casting-type calcifications is not a prognostic factor in unifocal small invasive breast cancer: a populationbased retrospective cohort study. J Surg Oncol 100:670-674

17. Zhou W, Sollie T, Tot T, Blomqvist C, Abdsaleh S, Liljegren G et al (2017) Ductal breast carcinoma in situ: mammographic features and its relation to prognosis and tumour biology in a population based cohort. Int J Breast Cancer 2017:4351319

18. Zhou W, Sollie T, Tot T, Pinder SE, Amini RM, Blomqvist C et al (2014) Breast cancer with neoductgenesis: histopathological criteria and its correlation with mammographic and tumour features. Int $\mathrm{J}$ Breast Cancer 2014:581706

19. Amendoeira I, Apostolikas N, Bellocq JP, Bianchi S, Boecker W, Borisch B, et al (2006) Quality assurance guidelines for pathology. In: Perry N, Broeders M, de Wolf C, Törnberg S, Holland R, von Karsa L (eds) European guidelines for quality assurance in breast cancer screening and diagnosis, 4th edn. European Commission, Luxemburg, pp 219-311

20. Oakes SR, Hilton HN, Ormandy CJ (2006) The alveolar switch: coordinating the proliferative cues and cell fate decisions that drive the formation of lobuloalveoli from ductal epithelium. Breast Cancer Res 8:207 
IV. Zombori T, Cserni G. Patterns of regression in breast cancer after primary systemic treatment. Pathol Oncol Res. [under consideration] 


\section{Pathology \& Oncology Research \\ Patterns of regression in breast cancer after primary systemic treatment \\ --Manuscript Draft--}

Manuscript Number:

Full Title:

Article Type:

Keywords:

Corresponding Author:
PORE-D-18-00442R1

Patterns of regression in breast cancer after primary systemic treatment

Original Article

primary systemic therapy; breast cancer; regression pattern; molecular subtypes

Tamás Zombori, M.D.

Szegedi Tudomanyegyetem

Szeged, Csongrád HUNGARY

Corresponding Author Secondary Information:

Corresponding Author's Institution:

Szegedi Tudomanyegyetem

Corresponding Author's Secondary Institution:

First Author:

Tamás Zombori

First Author Secondary Information:

Order of Authors:

Tamás Zombori

Gábor Cserni, D.Sc.

Order of Authors Secondary Information:

Funding Information:

National Research, Development and

Innovation Office grant

Dr. Gábor Cserni

(GINOP-2.3.2-15-2016-00020)

Abstract:

Despite national guidelines, the evaluation of effects of primary systemic treatment (PST) in breast cancer is a complex challenge. Our aims were to evaluate the response patterns focusing on correlations of radiological and pathological tumor size, regression heterogeneity in different molecular subtypes, cellularity changes and the incidence of enlarged, multinucleated neoplastic cells related to therapy.

Slides of pretreatment biopsies and resection specimens of consecutive cases were reevaluated focusing on heterogeneity of regression per whole slide, and 40x or 100x magnification fields. Alteration in cellularity and the presence of multinucleated tumor giant cells were noted. The correlation of pathological and radiological sizes and their alterations were analyzed by Spearman rank correlation.

The present study included 106 tumors. A decrease in size (84.9\%) and cellularity $(76.4 \%)$ was noted in all molecular subtypes. Inhomogeneous regression was found in $45.3 \%$, with minor inhomogeneity in the majority. Scatter pattern regression was seen only in 8 cases $(7.5 \%)$. Significant correlations were found between the pathological and radiological sizes $(p=0.02)$, and between the alterations of cellularity and pathological and radiological size $(p=0.04 ; p=0.03$, respectively). Multinucleated tumor giant cells were noted in $17.9 \%(n=19)$, nearly exclusively in cases treated with PST including taxanes.

Regression inhomogeneity following PST is present in about half of the cases, and is not related to molecular subtypes. The evaluation of the maximum area of the tumor bed is recommended for the proper evaluation of regression. Multinucleated tumor giant cells are related to PST including taxane derivate, and may cause upgrading.

Response to Reviewers:

We thank the reviewers for their assessment and evaluation of our manuscript as well as for their comments, which we used to revise our manuscript.

Comments for the Author:

This study evaluated the regression pattern after PST.

Q1: What is the difference between PST and PFS? 
Primary systemic therapy (PST) - for the purpose of this study - was defined as chemotherapy prior to surgical process, either in the neoadjuvant or in the palliative setting. Patients receiving primary endocrine therapy were excluded from the study. Unfortunately, we do not really understand, what the reviewer means by his question. We thought about a typographical error in our manuscript, but by using the search function of the word processor, we found no trace of the abbreviation PFS. To our knowledge, this conventionally means progression free survival. Our study did not evaluate survival data, and had no ethical approval for outcome analysis.

Q2: Is there any suggestion, how the clinical practice can take advantage from these results?

There are some studies listed in the discussion, where regression is monitored by taking interim core needle biopsies. The prevalence of these regression patterns was not assessed previously. As our findings demonstrated, inhomogeneity is present in half of all cases, while major inhomogeneity is seen in approximately $10 \%$. Especially in the latter cases, biopsies may be misleading regarding the effect of PST. This may perhaps be overcome by increasing the sites sampled or the number of cores taken. This may be considered one clinically useful aspect of our study. The second clinically relevant finding may relate to the introductory example: a post-PST breast conserving resection with a large area of empty tumor bed in the specimen but also tumor bed in the inked margin may not be a sufficient evidence of complete regression.

Part of this has already been included in the discussion, but we have added some further lines to better highlight these clinical aspects, in the paragraph quoted below:

Several ongoing or completed studies on PST feature post-PST biopsies as parts of the design [34-38]. By taking interim or final biopsies, pathological response and the effects of treatment can be characterized. Tumor heterogeneity, especially the scatter pattern of regression may have an impact on these studies. Limited sampling by biopsies may be the source of misinterpretations, if the biopsy is taken from the part of tumor bed showing complete response, or another part lacking any response. To avoid these diagnostic pitfalls, generous sampling by multiple biopsies is recommended for cases showing the extremes on the scale of regression, if the assessment of the complete tumor bed is not feasible. The results may also have an impact on the management of cases similar to the introductory example: an empty tumor bed with tumor bed on the inked margin may not be a perfect evidence of pCR or complete tumor resection.

We hope that the revision will satisfies the reviewer(s) and the editors.

Sincerely,

Tamás Zombori MD, Gábor Cserni MD, DSc 
Patterns of regression in breast cancer after primary systemic treatment

Authors:

Tamás Zombori, M.D. ${ }^{1}$, Gábor Cserni, M.D., Ph.D., D.Sc. ${ }^{1,2}$

${ }^{1}$ Department of Pathology, University of Szeged, Faculty of Medicine

${ }^{2}$ Department of Pathology, Bács-Kiskun County Teaching Hospital

\section{Corresponding author:}

Tamás Zombori, M.D.

Department of Pathology, University of Szeged, Faculty of Medicine

Állomás u. 1. Szeged, 6725 Hungary

Phone: +36308447190

E-mail:zomtam@gmail.com

\section{Acknowledgment}

We gratefully acknowledge the assistance of Réka Némedi (MD) in collecting treatment related data of the patients and that of Mihály Dezső in photography work. This study was partly funded by the National Research, Development and Innovation Office grant GINOP2.3.2-15-2016-00020

\section{Conflicts of interest statement}

No editorial or financial conflicts of interest exist for this submission. 


\begin{abstract}
Despite national guidelines, the evaluation of effects of primary systemic treatment (PST) in breast cancer is a complex challenge. Our aims were to evaluate the response patterns focusing on correlations of radiological and pathological tumor size, regression heterogeneity in different molecular subtypes, cellularity changes and the incidence of enlarged, multinucleated neoplastic cells related to therapy.

Slides of pretreatment biopsies and resection specimens of consecutive cases were reevaluated focusing on heterogeneity of regression per whole slide, and 40x or 100x magnification fields. Alteration in cellularity and the presence of multinucleated tumor giant cells were noted. The correlation of pathological and radiological sizes and their alterations were analyzed by Spearman rank correlation.
\end{abstract}

The present study included 106 tumors. A decrease in size (84.9\%) and cellularity (76.4\%) was noted in all molecular subtypes. Inhomogeneous regression was found in $45.3 \%$, with minor inhomogeneity in the majority. Scatter pattern regression was seen only in 8 cases (7.5\%). Significant correlations were found between the pathological and radiological sizes $(\mathrm{p}=0.02)$, and between the alterations of cellularity and pathological and radiological size ( $\mathrm{p}=0.04 ; \mathrm{p}=0.03$, respectively). Multinucleated tumor giant cells were noted in 17.9\% ( $\mathrm{n}=19)$, nearly exclusively in cases treated with PST including taxanes.

Regression inhomogeneity following PST is present in about half of the cases, and is not related to molecular subtypes. The evaluation of the maximum area of the tumor bed is recommended for the proper evaluation of regression. Multinucleated tumor giant cells are related to PST including taxane derivate, and may cause upgrading.

Key words: primary systemic therapy, breast cancer, regression pattern, molecular subtypes 
A 40-year-old woman with a cT2(34 mm)NOM0 grade 3 estrogen receptor (ER) positive and human epidermal growth factor receptor 2 (HER2) negative breast cancer of no special type (Fig. 1A) received 6 cycles of docetaxel, epirubicin and cyclophosphamide as primary systemic treatment (PST), showed substantial regression on imaging, and underwent breast conserving surgery with sentinel node biopsy. The localization metal clip was not included in the first excision and a re-excision was needed to remove the clip, too. The first surgical specimen included an empty tumor bed area with $11.4 \mathrm{~mm}$ greatest dimension, but the empty tumor bed was in the margin (Fig. 1B). The second specimen sent for histology also included the localization clip and a tumor bed area harboring both ductal carcinoma in situ and a 6 mm-large residual grade 3 invasive carcinoma (ypT1b) (Fig. 1C and 1D). The cited introductory example highlights that tumor regression may be misleadingly inhomogeneous, and this may lead to the false impression of complete regression on one end and lack of regression on the other end of the spectrum unless the full tumor bed is investigated.

PST of breast cancer has become more frequent recently. This approach to systemic treatment is currently applied in bulky ( $>2 \mathrm{~cm})$ tumors or locally advanced cancers [1]. The radiologic and pathologic interpretation of regression is sometimes controversial due to some mismatch between the entities used for assessment. There is no internationally agreed consensus on how different imaging modalities should be priorized and specimen handling is also rather heterogeneous.

The presence or absence of regression is evaluated by radiologic modalities, namely ultrasonography (US), mammography and magnetic resonance imaging (MRI). This examination influences the continuation, shift or termination of PST and the multidisciplinary decision about surgical treatment. After the operation, the pathological examination reveals the degree of regression: pathological complete regression (pCR) on one end, and the complete lack of regression on the other end of the spectrum. The scale of regression affects further treatment decisions. Therefore, a standard approach to the evaluation of the breast specimen is crucial. To reach this aim, national guidelines have been developed in individual countries like Australia [2], Belgium [3], Germany [4], the United Kingdom [5], the Netherlands [6], the United States [7] and Hungary [8]. 
Despite these guidelines or reviews [9; 10] aiming at some uniformity in breast cancer reporting, there are several inconsistencies, namely in specimen work-up, definition of $\mathrm{pCR}$, patterns and grades of regression.

After PST, the identification of the tumor bed may be difficult because the tumor may have become less firm, and less well circumscribed. Therefore, gross examination must be correlated with the clinical and especially radiological localization to ensure that the correct area is sampled. Systematic sampling should include the grossly visible tumor bed or the location of clip markers and neighboring areas to incorporate the area involved by carcinoma before treatment [10]. Digital photos, specimen mammography images or drawings should be taken for helping the comparison between clinical and morphological findings.

Histopathological evaluation is based on sampling: representative areas are chosen for tissue blocks during grossing, and a tissue section represents about one thousandth of the whole thickness of the tissue block. It is obvious, that the more thorough the sampling, the more details one can discover under the microscope, especially in non-homogeneous lesions exemplified in the first paragraph and Figure 1.

In case of inhomogeneous, scattered focal regression, the assessment of tumor size may be problematic, as well. The dimension of the largest invasive focus may deviate from the largest dimension of the residual tumor affected area in the tumor bed (i.e. the extent) [11].

According to the United States' Food and Drug Administration (FDA), 'Pathological complete response is defined as the absence of residual invasive cancer (ypT0ypN0 or ypT0isypN0) on evaluation of the complete resected breast specimen and all sampled regional lymph nodes following completion of neoadjuvant systemic therapy' [12].The AJCC has endorsed the same definition [13]. This recommendation is based on the findings of the Collaborative Trials in Neoadjuvant Breast Cancer project. In this study, there was no difference in event-free and overall survival of patients having ypT0ypN0 or ypTisypN0 breast cancer [14]. On the contrary, the German and Austrian Breast Groups demonstrated significant worsening in event-free survival of ypTisypN0 versus ypT0ypN0 breast cancer cases [15]. Therefore, an alternative definition of complete response was proposed by this group, which excludes both residual ductal carcinoma in situ (DCIS) and invasive carcinoma in the breast (ypT0ypN0 only). 
Regression and its scale can be characterized by different parameters, like the size of residual invasive carcinoma, lymph node status, tumor cellularity, tumor grade, proportion of tumor remaining in breast $(\%)$ and finally the size of tumor bed in two dimensions. Several regression grading systems based on these parameters have been introduced and validated, including those described by Miller and Payne [16], Pinder [17], Denkert and Sinn [18] and Sataloff [19].

Another feature of response to neoadjuvant therapy is homogeneity or heterogeneity of the regression. According to Provenzano and coworkers, the patterns of residual disease are the following: homogenous regression (cellularity decreased, size unchanged), inhomogeneous regression (cellularity decreased, size variable, small areas without residual disease), "scatter pattern" (cellularity decreased, size variable, tumor bed slides without residual disease) and "concentric shrinkage" (CS) (size decreased, cellularity similar) [10]. Especially the "scatter pattern" may lead to diagnostic pitfalls if not systematically sampled.

Not only the size and cellularity change following PST, but grade may also be altered. After PST, bizarre and/or macronucleated neoplastic giant cells may sometimes be found in the tumor bed. These cells are generally attributed to the effects of chemotherapy. The presence of these bizarre cells may increase the posttreatment grade, whereas a reduction in the proliferating cells may decrease it.

The aims of the present study were to evaluate the response patterns in breast cancers after PST, focusing on correlations of radiological and pathological tumor sizes, regression heterogeneity in the tumor bed and in the axilla in different molecular subtypes of breast cancer, cellularity changes between biopsy and resection specimen, correlation between cellularity and size alterations and the incidence of macronucleated, bizarre neoplastic cells related to therapy.

\section{Materials and methods}

Consecutive invasive breast carcinomas treated with PST and operated on at the BácsKiskun County Teaching Hospital, Kecskemét or at the Department of Surgery, University of Szeged from 2015 through February 2018 and from 2013 through May 2018, respectively were included. Additionally some earlier cases (from between 2010-2014) collected for a 
previous study on PST $(n=8)$ were also included. Exclusion criteria were unavailability of slides of either the biopsy or the excision specimen and primary endocrine therapy.

Clinical data, namely age, gender, laterality, type of surgery, pre- and posttreatment size determined by US, mammography and MRI (as available), primary systemic therapy were collected from medical charts. Pathological data including ER, progesterone receptor (PR) and HER-2 status, ypT and ypN categories [13], TR and NR tumor and node regression categories [20], pre- and posttreatment histological grade, pathological size (both the largest invasive focus and extent of the area involved by tumor, either invasive or in situ) were obtained from the histopathology reports. The immunohistochemical surrogate classification of molecular subtypes of breast carcinomas was utilized according to the St. Gallen Consensus Conference [21]. The latest recommendations of American Society of Clinical Oncology were applied for the evaluation of HER-2 immunohistochemical staining [22].

Both departments have used the same work-up methodology recommended by the 3rd Hungarian Consensus Conference on Breast Cancer [8] including radiological localization, systematic sampling and clinical-pathological correlation on multidisciplinary meetings.

All hematoxyline-eosin stained tumor (bed) containing slides of biopsy and excision specimens were analyzed. The cellularity was estimated by two pathologists (TZ \& GC) both on biopsy and excision specimens. Consensus was always reached.

The tumor bed areas showing complete regression or the absence of any regression pattern were evaluated on low (4x) and medium (10x) power fields (field areas: $0.24 \mathrm{~mm}^{2}$ and $0.005 \mathrm{~mm}^{2}$, respectively). The presence of whole slides, any low power field or any medium power field showing complete response or the lack of any response were noted. Homogenous regression was defined as pCR (Fig.2A), absence of regression on all slides (Fig.2B) and uniform degree of regression on all slides (Fig.2C). Any other pattern was perceived as inhomogeneous response (Fig.2E-G). The latter included the so called "scatter pattern" [17], the CS [17], which was identified in case of reduction of tumor size with similar cellularity (Fig.2D).

The cells having enlarged cytoplasm, multiple and/or enlarged bizarre hyperchromatic nuclei with different size and shape were labelled as "monster cells" for the purpose of this study (Fig.2H-I). 
The slides of axillary sentinel lymph node excisions and/or axillary lymph node dissections were reevaluated and the presence or absence of metastasis and regression were documented. If metastatic nodes were seen with and without regression, inhomogeneous axillary response was identified.

The alteration of pre- and posttreatment cellularity and size; and the correlation between radiological (exclusively uniformly available US data) and pathological size were analyzed by the Spearman rank model. All statistical tests were one-sided, and $p<0.05$ values were considered statistically significant. We utilized the SPSS Statistics software (IBM, SSPS 22.0, Armonk, NY USA).

\section{Results}

In this series, 106 cases were included: 56 and 50 patients from the University of Szeged and the Bács-Kiskun County Teaching Hospital, respectively. The basic clinical characteristics of these cases, namely age, type of surgery, histological type of tumor, ypT, ypN categories, pretreatment grade and therapy received are summarized in Table 1.Seven patients having stage IV disease defined by distant metastasis received palliative chemotherapy before surgery.

The morphological parameters evaluated are displayed in Table 2. In all IHC approached molecular subtypes defined by the St. Gallen Consensus Conference in 2013, diminution was the most frequent size alteration after PST. The Spearman rank correlation revealed that the concordance between post-treatment pathological size and radiological size (defined by US examination) was high $(\mathrm{p}=0.002)$.

Regarding the homogeneity of regression, the luminal A, HER-2 and triple negative breast cancers (TNBCs) showed more homogeneity, whereas luminal B cases demonstrated more inhomogeneity. Unfortunately, statistical analysis could not been applied due to the low case number in the groups. Lack of any regression, uniform degree of regression and pCR were observed in $7.5 \%, 18.8 \%$ and $28.3 \%$ of all cases, respectively. The vast majority of inhomogeneous regression was minor inhomogeneity (36.7\% of all cases). The scatter pattern was identified in only 8 cases $(7.5 \%)$, while $\mathrm{CS}$ was the rarest $(\mathrm{n}=2 ; 1.8 \%)$. The regression inhomogeneity is demonstrated in Table 3 displaying the distribution of complete regression and the lack of any regression patterns at the different magnifications evaluated. In the lymph 
node specimens, homogeneity was more frequent (homogeneity: $45.3 \%$ versus inhomogeneity: $23.5 \%$ of all cases). In cases having neither metastasis nor regression in the lymph nodes, homogeneity of regression or its lack could not be evaluated (31.2\%).

Cellularity changes reflected decrease in most cases (two thirds of all patients) but an increase was recorded in a significant minority (15.1\%). The correlation between changes in cellularity and the alterations of post-treatment pathological and radiological tumor sizes compared to the pretreatment US size were significant ( $\mathrm{p}=0.04$ and $\mathrm{p}=0.03$, respectively). After exclusion of cases showing pCR following PST (where grade alteration was not interpretable) the grade of tumors was unchanged in $72.4 \%$. Upgrading and downgrading were detected in 10 and 10 cases (13.8\% and 13.8\%), respectively. The latter was not seen among patients having TNBC.

"Monster" cells were seen in 17.9\% $(\mathrm{n}=19)$ of all cases. They were present in pre- and posttreatment grade 2 and 3 tumors exclusively. Their possible influence on grade alteration and association with PST are demonstrated in Table 4. Among these findings, the following are underlined: in 5 cases, upgrading (grade 2 to post-treatment y-grade 3) was detected in presence of "monster" cells and the monster cells were present only (all but one case) in patients who received PST including a taxane.

No correlation was found between the molecular subtypes and treatment related alteration in (pathological) size, cellularity, grade, the homogeneity of regression in lymph node specimens and presence of "monster" cells.

\section{Discussion}

The concepts of PST were developed in the last years and offer an alternative option for patients having primary breast cancer. The aims of PST are combination of systemic treatment and surgical treatment in order to eliminate all tumor cells, down staging breast cancers to make them operable by breast conserving options, and enabling the assessment of regression by pathological means [23-25]. In PST studies, the pathological diagnosis is the most important parameter for the generation of study endpoints [26]. The histopathological changes after PST are complex, therefore careful systematic analysis of the specimen is required for accurate diagnosis and treatment. The standardization of specimen handling and 
histological interpretation is essential for approaching pCR as an indicator in PST studies, or for measuring residual disease [10].

Although one of the most cardinal features of residual disease is the tumor size, it is often difficult to determine after PST. Besides the hardships of systematic sampling of the tumor bed, residual tumor may be present as multiple, small scattered foci. In the latter case, the size of the largest invasive focus determines the ypT category according to the $8^{\text {th }}$ edition of the AJCC staging system [13], while the extent defined by the largest dimension inclusive of all independent invasive foci may be better for comparison with radiologic size [12]. Our findings have demonstrated, that pathological tumor size correlates with radiological (US) size, and the alteration of pathological size is in keeping with radiological findings [27; 28].

Primary chemotherapy selectively eliminates the proliferating cells, therefore the mitotic activity and the cellularity may decrease. Though, the change in cellularity is one of the most representative features of PST [29], it is not recorded routinely in the histopathological reports, because it is not easy to assess, lacks standardization and is an important parameter in only some tumor-response systems [16;30] while it is not one in others [31-33]. Cellularity is utilized in two regression grading systems: in the Miller-Payne and in the Residual Cancer Burden system (RCB). Regarding the five-tiered Miller-Payne system, the pre- and post PST cellularity are compared, and the presence of invasive carcinoma is considered [16]. The four-tiered RCB is based on the size of the tumor bed in two dimensions, tumor cellularity in the post-treatment specimen, the proportion of DCIS in residual cancer, the number of lymph nodes with residual metastasis and the size of the largest lymph node metastasis [30]. In the present series, biopsies taken before PST and resection specimen were evaluated for cellularity changes. In the vast majority of the cases, cellularity has declined and a significant correlation was detected between alterations of cellularity and (pathological) size.

Our findings suggest that homogeneity and inhomogeneity of regression are not associated with any molecular subtypes, and both are present approximately in half of the cases. The majority of inhomogeneous regression represented minor inhomogeneity seen in differences between one and the other medium or low power field, while the scatter pattern and CS were exceptionally rare. Although, the most remarkable pattern is the scatter pattern regarding the problems of tumor bed sampling (Figure 1 and introductory example), where 
complete slides may be present without residual cancer, minor heterogeneity may also cause diagnostic controversy if only core biopsy is taken after PST.

Several ongoing or completed studies on PST feature post-PST biopsies as parts of the design [34-38]. By taking interim or final biopsies, pathological response and the effects of treatment can be characterized. Tumor heterogeneity, especially the scatter pattern of regression may have an impact on these studies. Limited sampling by biopsies may be the source of misinterpretations, if the biopsy is taken from the part of tumor bed showing complete response, or another part lacking any response. To avoid these diagnostic pitfalls, generous sampling by multiple biopsies is recommended for cases showing the extremes on the scale of regression, if the assessment of the complete tumor bed is not feasible. The results may also have an impact on the management of cases similar to the introductory example: an empty tumor bed with tumor bed on the inked margin may not be a perfect evidence of pCR or complete tumor resection.

Histological grade of breast cancer is one of the most established traditional prognostic factors. Honkoop and coworkers have found significant decline in mitotic activity following PST [39], while Sharkey et al have identified significant increase of nuclear pleomorphism [40]. While the decline of mitotic count can lead to "downgrading", more severe nuclear atypia could result in "upgrading". The result of these contradirectional changes may alter the posttreatment histological grade. We have demonstrated that up- and downgrading are rare, especially because the majority of PST case belong to grade 3. In half of the cases with upgrading, monster cells were present.

The monster cells (Figure 2H-I) are giant tumor cells often having hyperchromatic macronuclei or multilobated or multiple nuclei and they are associated with effects of PST [40]. The presence of these cells was associated with taxane treatment. The principal effect of taxanes is the disruption of microtubule function, including the blockage of the mitotic spindle. Microtubules are essential to cell division, and taxanes stabilize GDP-bound tubulin in the microtubule, thereby inhibiting the process of cell division as depolymerization is prevented. The tumor cells are not able to divide after the duplication of their chromatin content, and the result may be the formation of macronucleated "monster" cells. Our findings suggest that the presence of these monster cells may increase nuclear atypia and therefore it may lead to upgrading following PST. Due to polyploidization, such cells are also expected to 
show an increased copy number of many genes, including HER2, leading to a post-treatment positive status of questionable therapeutic significance in these cells [41].

Limitations of the present study could be the low number of cases and the exclusion of patients receiving primary hormone therapy (PHT). Fukada and coworkers have reported that CS is significantly more frequent in luminal breast cancers following PHT, and these patients had significantly better outcome than patients having other patterns [42]. In contrast, there was no significant correlation between regression patterns and molecular subtypes in present work. This discrepancy may be explained by the exclusion of cases with PHT.

To our knowledge, this is the first study describing the distribution of regression heterogeneity according to molecular subtypes. Our findings suggest that regression may be inhomogeneous in half of the cases, and it does not seem to be related to any molecular subtype, therefore the evaluation of the whole tumor bed is recommended for the best assessment of regression. The "monster" cells are related to PST including taxane derivate, and may cause upgrading in tumors with non-high grade nuclei at the start of PST. 


\section{References}

1. Thompson AM, Moulder-Thompson SL (2012) Neoadjuvant treatment of breast cancer. Ann Oncol 10:x231-6. https://doi.org/10.1093/annonc/mds324

2. Royal College of Pathologists of Australasia (2012) Invasive Breast cancer structured reporting protocol (2nd Edition) https://www.rcpa.edu.au/getattachment/7b70b3e5-5dca-403f893e-638815f487b1/Protocol-invasive-breast-cancer.aspx. Accessed 26 June 2018

3. K. Lambein, K. Van de Vijver, D. Faverly, C. Colpaert (2011) Belgian guidelines for laboratory handling and pathology reporting of breast carcinoma after neoadjuvant therapy. Belg J Clin Oncol 5:144-153.

4. Arbeitsgemeinschaft Gynäkologische Onkologie Studiengruppe (AGO) https://www.agoonline.de/fileadmin/downloads/leitlinien/mamma/201803/EN/Gesamt PDF Englisch/Updated_Guidelines 2018.pdf. Accessed 26 June 2018

5. NHS Breast Screening Program (2005) Pathology reporting of breast disease: A joint document incorporating the third edition of the NHS Breast Screening Programs Guidelines for pathology reporting in breast cancer screening and the second edition of the Royal College of Pathologists' Minimum dataset for breast cancer histopathology. NHSBSP Publication No 58. NHS Cancer Screening Programs jointly with the Royal College of Pathologists.

6. Integraal Kankercentrum Nederland (2012) Beoordeling na neoadjuvante chemo- of endocriene therapie. http://www.oncoline.nl/breastcancer 2012. Accessed 26 June 2018

7. College of American Pathologists. Protocol for the examination of specimens from patients with invasive carcinoma of the breast.

http://www.cap.org/ShowProperty?nodePath=/UCMCon/Contribution\%20Folders/WebConte nt/pdf/cp-breast-invasive-16protocol-3300.pdf Accessed 36 June 2018

8. Cserni G, Kulka J, Francz M, Járay B, Kálmán E, Kovács I, Krenács T, Udvarhelyi N, Vass L (2016) Pathological diagnosis, work-up and reporting of breast cancer. Recommendations of the 3rd Hungarian Consensus Conference on Breast Cancer. Magy Onkol 60:209-28. [Hungarian] 
9. Park CK, Jung WH, Koo JS (2016) Pathologic evaluation of breast cancer after neoadjuvant therapy. J Pathol Transl Med 50:173-80. https://doi.org/10.4132/jptm.2016.02.02.

10. Provenzano E, Bossuyt V, Viale G, Cameron D, Badve S, Denkert C, MacGrogan G, PenaultLlorca F, Boughey J, Curigliano G, Dixon JM, Esserman L, Fastner G, Kuehn T, Peintinger F, von Minckwitz G, White J, Yang W, Symmans WF (2015) Residual Disease Characterization Working Group of the Breast International Group-North American Breast Cancer Group Collaboration. Standardization of pathologic evaluation and reporting of postneoadjuvant specimens in clinical trials of breast cancer: recommendations from an international working group. Mod Pathol 28:1185-201. https://doi.org/10.1038/modpathol.2015.74.

11. Tot $\mathrm{T}$ (2012) The role of large-format histopathology in assessing subgross morphological prognostic parameters: a single institution report of 1000 consecutive breast cancer cases. Int J Breast Cancer. 2012:395415. https://doi.org/10.1155/2012/395415.

12. U.S. Food and Drug Administration (2014) Guidance for Industry: Pathological complete response in neoadjuvant treatment of high-risk early-stage breast cancer: use as an endpoint to support accelerated approval.

http://www.fda.gov/downloads/Drugs/GuidanceComplianceRegulatoryInformation/Guidances /UCM305501.pdf Accessed 26 June 2018

13. AJCC (2016) Cancer staging manual 8th edn. Springer, Chicago

14. Cortazar P, Zhang L, Untch M, Mehta K, Costantino JP, Wolmark N, Bonnefoi H, Cameron D, Gianni L, Valagussa P, Swain SM, Prowell T, Loibl S, Wickerham DL, Bogaerts J, Baselga J, Perou C, Blumenthal G, Blohmer J, Mamounas EP, Bergh J, Semiglazov V, Justice R, Eidtmann H, Paik S, Piccart M, Sridhara R, Fasching PA, Slaets L, Tang S, Gerber B, Geyer CE Jr, Pazdur R, Ditsch N, Rastogi P, Eiermann W, von Minckwitz G (2014) Pathological complete response and long-term clinical benefit in breast cancer: the CTNeoBC pooled analysis. Lancet 384:164-72. https://doi.org/10.1016/S0140-6736(13)62422-8.

15. von Minckwitz G, Untch M, Blohmer JU, Costa SD, Eidtmann H, Fasching PA, Gerber B, Eiermann W, Hilfrich J, Huober J, Jackisch C, Kaufmann M, Konecny GE, Denkert C, Nekljudova V, Mehta K, Loibl S (2012) Definition and impact of pathologic complete response on prognosis after neoadjuvant chemotherapy in various 
intrinsic breast cancer subtypes. J Clin Oncol 30:1796-804.

https://doi.org/10.1200/JCO.2011.38.8595.

16. Mamounas EP, Anderson SJ, Dignam JJ, Bear HD, Julian TB, Geyer CE Jr, Taghian A, Wickerham DL, Wolmark N (2012) Predictors of locoregional recurrence after neoadjuvant chemotherapy: results from combined analysis of National Surgical Adjuvant Breast and Bowel Project B-18 and B-27. J Clin Oncol 30:3960-6. https://doi.org/10.1200/JCO.2011.40.8369.

17. Pinder SE, Provenzano E, Earl H, Ellis IO (2007) Laboratory handling and histology reporting of breast specimens from patients who have received neoadjuvant chemotherapy. Histopathology 50:409-17. https://doi.org/10.1111/j.13652559.2006.02419.x

18. Denkert C, Schickling O, von Minckwitz G (2006) Preoperative chemotherapy in breast cancer and the development of new predictive markers. Verh Dtsch Ges Pathol 90:114-23. [German]

19. Sataloff DM, Mason BA, Prestipino AJ, Seinige UL, Lieber CP, Baloch Z (1995) Pathologic response to induction chemotherapy in locally advanced carcinoma of the breast: a determinant of outcome. J Am Coll Surg 180:297-306.

20. Wells CA, Amendoeira I, Bellocq JP, Bianchi S, Boecker W, Borisch B, Bruun Rasmussen B, Callagy GM, Chmielik E, Cordoba A, Cserni G, Decker T, DeGaetano J, Drijkoningen M, Ellis IO, Faverly DR, Foschini MP, Frković-Grazio S, Grabau D, Heikkilä P, Iacovou E, Jacquemier J, Kaya H, Kulka J, Lacerda M, Liepniece-Karele I, Martinez-Penuela J, Quinn CM, Rank F, Regitnig P, Reiner-Concin A, Sapino A, Tot T, Van Diest PJ, Varga Z, Wesseling J, Zolota V, Zozaya-Alvarez E. (2012) Pathology update. Quality assurance guidelines for pathology. In: European guidelines for quality assurance in breast cancer screening and diagnosis. Fourth edition, Supplements. Perry N, Broeders M, de Wolf C, Törnberg S, Holland R, von Karsa L (eds.). European Commission, Office for Official Publications of the European Union, Luxembourg, pp. 73-120.

21. Goldhirsch A, Winer EP, Coates AS, Gelber RD, Piccart-Gebhart M, Thürlimann B, Senn HJ; Panel members (2013) Personalizing the treatment of women with early 
breast cancer: highlights of the St Gallen International expert consensus on the primary therapy of early breast cancer 2013. Ann Oncol 24:2206-23. https://doi.org/10.1093/annonc/mdt303.

22. Giordano SH, Temin S, Chandarlapaty S, Crews JR, Esteva FJ, Kirshner JJ, Krop IE, Levinson J, Lin NU, Modi S, Patt DA, Perlmutter J, Ramakrishna N, Winer EP, Davidson NE (2018) Systemic therapy for patients with advanced human epidermal growth factor receptor 2-positive breast cancer: ASCO Clinical practice guideline update. J Clin Oncol [Epub ahead of print] https://doi.org/10.1200/JCO.2018.79.2697.

23. Kaufmann M, von Minckwitz G, Smith R, Valero V, Gianni L, Eiermann W, Howell A, Costa SD, Beuzeboc P, Untch M, Blohmer JU, Sinn HP, Sittek R, Souchon R, Tulusan AH, Volm T, Senn HJ (2003) International expert panel on the use of primary (preoperative) systemic treatment of operable breast cancer: review and recommendations. J Clin Oncol 21:2600-8. https://doi.org/10.1200/JCO.2003.01.136

24. Kaufmann M, Hortobagyi GN, Goldhirsch A, Scholl S, Makris A, Valagussa P, Blohmer JU, Eiermann W, Jackesz R, Jonat W, Lebeau A, Loibl S, Miller W, Seeber S, Semiglazov V, Smith R, Souchon R, Stearns V, Untch M, von Minckwitz G (2006) Recommendations from an international expert panel on the use of neoadjuvant (primary) systemic treatment of operable breast cancer: an update. J Clin Oncol 24:1940-9. https://doi.org/10.1200/JCO.2005.02.6187

25. von Minckwitz G, Blohmer JU, Raab G, Löhr A, Gerber B, Heinrich G, Eidtmann H, Kaufmann M, Hilfrich J, Jackisch C, Zuna I, Costa SD; German Breast Group (2005) In vivo chemosensitivity-adapted preoperative chemotherapy in patients with earlystage breast cancer: the GEPARTRIO pilot study. Ann Oncol 16:56-63. https://doi.org/10.1093/annonc/mdi001

26. Chollet P, Amat S, Cure H, de Latour M, Le Bouedec G, Mouret-Reynier MA, Ferriere JP, Achard JL, Dauplat J, Penault-Llorca F (2002) Prognostic significance of a complete pathological response after induction chemotherapy in operable breast cancer. Br J Cancer 86:1041-6. https://doi.org/10.1038/sj.bjc.6600210

27. Marinovich ML, Macaskill P, Irwig L, Sardanelli F, Mamounas E, von Minckwitz G, Guarneri V, Partridge SC, Wright FC, Choi JH, Bhattacharyya M, Martincich L, Yeh 
E, Londero V, Houssami N (2015) Agreement between MRI and pathologic breast tumor size after neoadjuvant chemotherapy, and comparison with alternative tests: individual patient data meta-analysis. BMC Cancer 15:662. https://doi.org/10.1186/s12885-015-1664-4.

28. Lee SC, Grant E, Sheth P, Garcia AA, Desai B, Ji L, Groshen S, Hwang D, Yamashita M, Hovanessian-Larsen L (2017) Accuracy of Contrast-Enhanced Ultrasound Compared With Magnetic Resonance Imaging in Assessing the Tumor Response After Neoadjuvant Chemotherapy for Breast Cancer. J Ultrasound Med 36:901-911. https://doi.org/10.7863/ultra.16.05060.

29. Rajan R, Poniecka A, Smith TL, Yang Y, Frye D, Pusztai L, Fiterman DJ, GalGombos E, Whitman G, Rouzier R, Green M, Kuerer H, Buzdar AU, Hortobagyi GN, Symmans WF (2004) Change in tumor cellularity of breast carcinoma after neoadjuvant chemotherapy as a variable in the pathologic assessment of response. Cancer 100:1365-73. https://doi.org/10.1002/cncr.20134

30. Abrial SC, Penault-Llorca F, Delva R, Bougnoux P, Leduc B, Mouret-Reynier MA, Mery-Mignard D, Bleuse JP, Dauplat J, Curé H, Chollet P (2005) High prognostic significance of residual disease after neoadjuvant chemotherapy: a retrospective study in 710 patients with operable breast cancer. Breast Cancer Res Treat 94:255-63. https://doi.org/10.1007/s10549-005-9008-8

31. Diaz J, Stead L, Shapiro N, Newell R, Loudig O, Lo Y, Sparano J, Fineberg S (2013) Mitotic counts in breast cancer after neoadjuvant systemic chemotherapy and development of metastatic disease. Breast Cancer Res Treat 138:91-7. https://doi.org/10.1007/s10549-013-2411-7

32: Boughey JC, Peintinger F, Meric-Bernstam F, Perry AC, Hunt KK, Babiera GV, Singletary SE, Bedrosian I, Lucci A, Buzdar AU, Pusztai L, Kuerer HM (2006) Impact of preoperative versus postoperative chemotherapy on the extent and number of surgical procedures in patients treated in randomized clinical trials for breast cancer. Ann Surg 244:464-70. https://doi.org/10.1097/01.sla.0000234897.38950.5c

33. Carey LA, Metzger R, Dees EC, Collichio F, Sartor CI, Ollila DW, Klauber-DeMore N, Halle J, Sawyer L, Moore DT, Graham ML (2005) American Joint Committee on 
Cancer tumor-node-metastasis stage after neoadjuvant chemotherapy and breast cancer outcome. J Natl Cancer Inst 97:1137-42. https://doi.org/10.1093/jnci/dji206

34. Neoadjuvant response-guided treatment of HER2 positive breast cancer (PREDIX HER2). ClinicalTrials.gov Identifier: NCT02568839

https://clinicaltrials.gov/ct2/show/NCT02568839?cond=breast+neoadjuvant+treatment \&rank=31 Accessed 2 August 2018

35. Efficacy and safety of Cabazitaxel versus weekly Paclitaxel as neo-adjuvant treatment in patients with triple negative or luminal B/HER2 normal BC (GENEVIEVE).

ClinicalTrials.gov Identifier: NCT01779479 https://clinicaltrials.gov/ct2/show/NCT01779479?cond=breast+neoadjuvant+treatment $\underline{\text { \&rank=69 }}$ Accessed 2 August 2018

36. Neoadjuvant Letrozole plus Metformin vs Letrozole plus Placebo for ER-positive postmenopausal breast cancer. ClinicalTrials.gov Identifier: NCT01589367 https://clinicaltrials.gov/ct2/show/NCT01589367?cond=breast+neoadjuvant+treatment \&rank=97 Accessed 2 August 2018

37. Neoadjuvant Tamoxifen in locally advanced breast cancer in a low/middle income country. ClinicalTrials.gov Identifier: NCT02806544 https://clinicaltrials.gov/ct2/show/NCT02806544?cond=breast+neoadjuvant+treatment

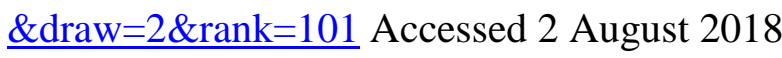

38. Leary A, Evans A, Johnston SR, A'Hern R, Bliss JM, Sahoo R, Detre S, Haynes BP, Hills M, Harper-Wynne C, Bundred N, Coombes G, Smith I, Dowsett M (2015) Antiproliferative effect of Lapatinib in HER2-positive and HER2-negative/HER3-high breast cancer: Results of the presurgical randomized MAPLE trial (CRUKE/06/039). Clin Cancer Res 21:2932-40. https://doi.org/10.1158/1078-0432.CCR-14-1428.

39. Honkoop AH, Pinedo HM, De Jong JS, Verheul HM, Linn SC, Hoekman K, Wagstaff J, van Diest PJ (1997) Effects of chemotherapy on pathologic and biologic characteristics of locally advanced breast cancer. Am J Clin Pathol 107:211-8. 
40. Sharkey FE, Addington SL, Fowler LJ, Page CP, Cruz AB (1996) Effects of preoperative chemotherapy on the morphology of resectable breast carcinoma. Mod Pathol 9:893-900.

41. Valent A, Penault-Llorca F, Cayre A, Kroemer G (2013) Change in HER2 (ERBB2) gene status after taxane-based chemotherapy for breast cancer: polyploidization can lead to diagnostic pitfalls with potential impact for clinical management. Cancer Gen 206:37-41. https://doi.org/10.1016/j.cancergen.2012.12.001

42. Fukada I, Araki K, Kobayashi K, Shibayama T, Takahashi S, Gomi N, Kokubu Y, Oikado K, Horii R, Akiyama F, Iwase T, Ohno S, Hatake K, Sata N, Ito Y (2018) Pattern of tumor shrinkage during neoadjuvant chemotherapy is associated with prognosis in low-grade luminal early breast cancer. Radiology 286:49-57. https://doi.org/10.1148/radiol.2017161548. 


\section{Figure legends:}

Figure 1. Example case with inhomogeneous (scatter pattern) regression.
A. Cellular tumor on core needle biopsy (HE, 40x)
B. Empty tumor bed with remnants of an intraductal papilloma in the firstly excised surgical specimen. No margin labeling ink on tumor (free margin?), but ink on the empty tumor bed. (HE, 40x)
C. Second surgical specimen included both areas of empty tumor bed (top right third) and residual invasive carcinoma (HE, 40x)
D. Higher magnification of part C, with residual invasive tumor cell clusters (HE, 400x)

Figure 2. Patterns of regression and peculiar cellular changes (monster cells) in post-treatment specimens.
A. Complete pathological regression (HE,40x)
B. Absence of any regression in the tumor bed (HE, 40x)
C. Homogenous regression (HE, 40x)
D. Concentric shrinkage pattern (HE, 40x)
E. Inhomogenous regression in a tumor bed. Big red circle and small yellow circle display 40x and 100x field area, respectively. (HE, 1x)
F. 40x field area of tumor bed on "E" slide shows complete response (HE, 40x)
G. 10x field area of tumor bed on "E" slide lacks any regression (HE, 100x)
H. and I. bizarre macronucleated "monster" cells (HE, 400x) 
Table 1. Clinical characteristics of patients. (SLND: sentinel lymph node dissection, ALND: axillary lymph node dissection, NST: breast carcinoma of no special type, ypT and ypN: categories defined by the $8^{\text {th }}$ edition of Cancer staging manual introduced by AJCC [13:AJCC])

\begin{tabular}{|c|c|}
\hline Clinical parameters & \\
\hline \multicolumn{2}{|l|}{ Age (year) } \\
\hline Range & $32-77$ \\
\hline mean / median & $54.5 / 55$ \\
\hline \multicolumn{2}{|l|}{ Type of surgery (n; (\%)) } \\
\hline Mastectomy & $71(66.9)$ \\
\hline breast conserving surgery & $35(33.1)$ \\
\hline \multicolumn{2}{|l|}{ Type of lymphadenectomy $(n ;(\%))$} \\
\hline $\begin{array}{ll} & \text { SLND } \\
\end{array}$ & $35(33.1)$ \\
\hline ALND & $80(75.4)$ \\
\hline SLND+ALND & $10(9.4)$ \\
\hline $\begin{array}{ll} & \text { None } \\
\end{array}$ & $1(0.9)$ \\
\hline \multicolumn{2}{|l|}{ Histological type of tumor $(\mathrm{n} ;(\%))$} \\
\hline $\begin{array}{rr}\text { NST } \\
\end{array}$ & $100(94.5)$ \\
\hline Lobular & $4(3.7)$ \\
\hline Other & $2(1.8)$ \\
\hline \multicolumn{2}{|l|}{ ypT (n; (\%)) } \\
\hline ypT0 & $25(23.6)$ \\
\hline ypTis & $5(4.7)$ \\
\hline ypT1a & $8(7.5)$ \\
\hline ypT1b & $9(8.6)$ \\
\hline ypT1c & $18(16.9)$ \\
\hline урT2 & $30(28.3)$ \\
\hline ypT3 & $9(8.6)$ \\
\hline ypT4 & $2(1.8)$ \\
\hline \multicolumn{2}{|l|}{ ypN (n; (\%)) } \\
\hline ypNo & $55(51.8)$ \\
\hline ypN1 & $26(24.5)$ \\
\hline ypN2 & $12(11.3)$ \\
\hline ypN3 & $11(10.3)$ \\
\hline no data & $2(1.8)$ \\
\hline \multicolumn{2}{|l|}{ Grade on core needle biopsy (n; (\%)) } \\
\hline 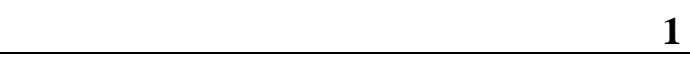 & $6(5.6)$ \\
\hline 2 & $41(38.7)$ \\
\hline 3 & $59(55.7)$ \\
\hline \multicolumn{2}{|l|}{ Treatment $(\mathrm{n} ;(\%))$} \\
\hline anthracycline $+/$ - targeted therapy & $9(8.6)$ \\
\hline taxane +/- platinum derivatives & $27(25.4)$ \\
\hline anthracycline + taxane & $70(66.0)$ \\
\hline
\end{tabular}


Table 2. Morphological features of cases evaluated, displayed according to the molecular subtypes of breast cancer [20]

\begin{tabular}{|c|c|c|c|c|}
\hline \multirow{3}{*}{ Morphological variable } & Luminal A & Luminal B & HER-2 & TNBC \\
\hline & $\mathrm{n}(\%)$ & $\mathrm{n}(\%)$ & $\mathrm{n}(\%)$ & $\mathrm{n}(\%)$ \\
\hline & $20(100)$ & $29(100)$ & $26(100)$ & $31(100)$ \\
\hline \multicolumn{5}{|l|}{ Radiological size alteration } \\
\hline shrinkage & $15(75)$ & $26(89)$ & $24(92.4)$ & 25 (80.6) \\
\hline growth & $2(10)$ & $0(0)$ & $2(7.6)$ & $4(12.9)$ \\
\hline unchanged & $2(10)$ & $3(11)$ & $0(0)$ & $2(6.5)$ \\
\hline no data & $1(5)$ & $0(0)$ & $0(0)$ & $0(0)$ \\
\hline \multicolumn{5}{|l|}{ Regression pattern in the resection specimen } \\
\hline Homogeneous & $14(70)$ & $10(34.4)$ & $15(57.6)$ & $19(61.3)$ \\
\hline pCR & $0(0)$ & $6(20.7)$ & $12(46.2)$ & $12(38.7)$ \\
\hline uniform degree of regression & $11(55)$ & $3(10.3)$ & $2(7.6)$ & $4(12.9)$ \\
\hline lack of any regression & $3(15)$ & $1(3.4)$ & $1(3.8)$ & $3(9.6)$ \\
\hline Inhomogeneous & $6(30)$ & $19(65.6)$ & $11(42.3)$ & $12(38.7)$ \\
\hline minor inhomogeneity & $5(25)$ & $17(58.8)$ & $9(34.7)$ & $8(25.9)$ \\
\hline "scatter pattern" & $1(5)$ & $2(6.8)$ & $1(3.8)$ & $3(9.6)$ \\
\hline $\begin{array}{cc}\text { concentric shrinkage } \\
\end{array}$ & $0(0)$ & $0(0)$ & $1(3.8)$ & $1(3.2)$ \\
\hline \multicolumn{5}{|l|}{ Regression pattern in the lymph node specimen } \\
\hline homogeneous & $9(45)$ & $12(41.4)$ & $13(50)$ & $14(45.2)$ \\
\hline inhomogeneous & $7(35)$ & $10(34.5)$ & $4(15.4)$ & $4(12.9)$ \\
\hline not applicable & $4(20)$ & $7(24.2)$ & $9(34.6)$ & $13(41.9)$ \\
\hline \multicolumn{5}{|l|}{ Change in cellularity } \\
\hline decreased & $15(75)$ & $23(79.5)$ & $21(80.8)$ & $22(70.9)$ \\
\hline increased & $2(10)$ & $3(10.3)$ & $4(15.4)$ & $7(22.6)$ \\
\hline unchanged & $3(15)$ & $1(3.4)$ & $1(3.8)$ & $2(6.5)$ \\
\hline no data & $0(0)$ & $2(6.8)$ & $0(0)$ & $0(0)$ \\
\hline \multicolumn{5}{|l|}{ Change in grade } \\
\hline decreased & $4(20)$ & $3(10.3)$ & $3(11.5)$ & $0(0)$ \\
\hline increased & $2(10)$ & $5(17.3)$ & $0(0)$ & $3(9.6)$ \\
\hline unchanged & $14(70)$ & $12(41.4)$ & $11(42.3)$ & $15(48.3)$ \\
\hline no data & $0(0)$ & $9(31.0)$ & $12(46.2)$ & $13(41.9)$ \\
\hline \multicolumn{5}{|l|}{ Presence of "monster" cells } \\
\hline present & $5(25)$ & $6(20.6)$ & $3(11.5)$ & $5(16.1)$ \\
\hline absent & $15(75)$ & $23(79.4)$ & $23(88.4)$ & $26(83.9)$ \\
\hline
\end{tabular}

(HER-2: human epidermal growth factor receptor-2; TNBC: triple negative breast cancer, pCR: pathological complete regression) 
Table 3. Morphological characteristics of regression patters

\begin{tabular}{|l|c|c|c|c|c|c|c|c|c|}
\hline \multirow{2}{*}{$\begin{array}{c}\text { Patterns of } \\
\text { inhomogeneity }\end{array}$} & \multicolumn{4}{|c|}{ complete regression pattern at magnification of/on } & \multicolumn{3}{c|}{ lack of any regression pattern at magnification of/on } \\
\cline { 2 - 11 } & $\mathbf{n}$ & $\mathbf{4 0 x}$ & $\mathbf{1 0 0 x}$ & whole slide & absent & $\mathbf{4 0 x}$ & $\mathbf{1 0 0 x}$ & whole slide & absent \\
\hline minor inhomogeneity & $\mathbf{3 9}$ & $19(48.7)$ & $14(35.8)$ & 0 & $6(15.5)$ & $15(35.5)$ & $9(23)$ & $3(7.8)$ & $12(30.7)$ \\
\hline scatter pattern & $\mathbf{7}$ & 0 & 0 & $7(100)$ & 0 & $2(28.5)$ & $3(43)$ & 0 & $2(28.5)$ \\
\hline concentric shrinkage & $\mathbf{2}$ & $2(100)$ & 0 & 0 & 0 & 0 & $1(50)$ & 0 & $1(50)$ \\
\hline
\end{tabular}

Note: When a pattern was present on the whole slide, it was also present in a medium power (10x) and low power field, too; but the numbers in the table reflect only the largest of the three areas assessed. 
Table 4. Relation between alterations of grade, therapy received and "monster" cells, respectively.

\begin{tabular}{|r|c|c|}
\hline & \multicolumn{2}{|c|}{ monster cells } \\
\hline Alteration of grade & present & absent \\
\hline decreased & 1 & 5 \\
\hline unchanged & 11 & 41 \\
\hline no data & 2 & 32 \\
\hline Therapy & & \\
\hline anthracycline +/- targeted therapy & 1 & 8 \\
\hline taxane +/- platinum derivatives & 4 & 23 \\
\hline anthracycline + taxane & 15 & 55 \\
\hline
\end{tabular}




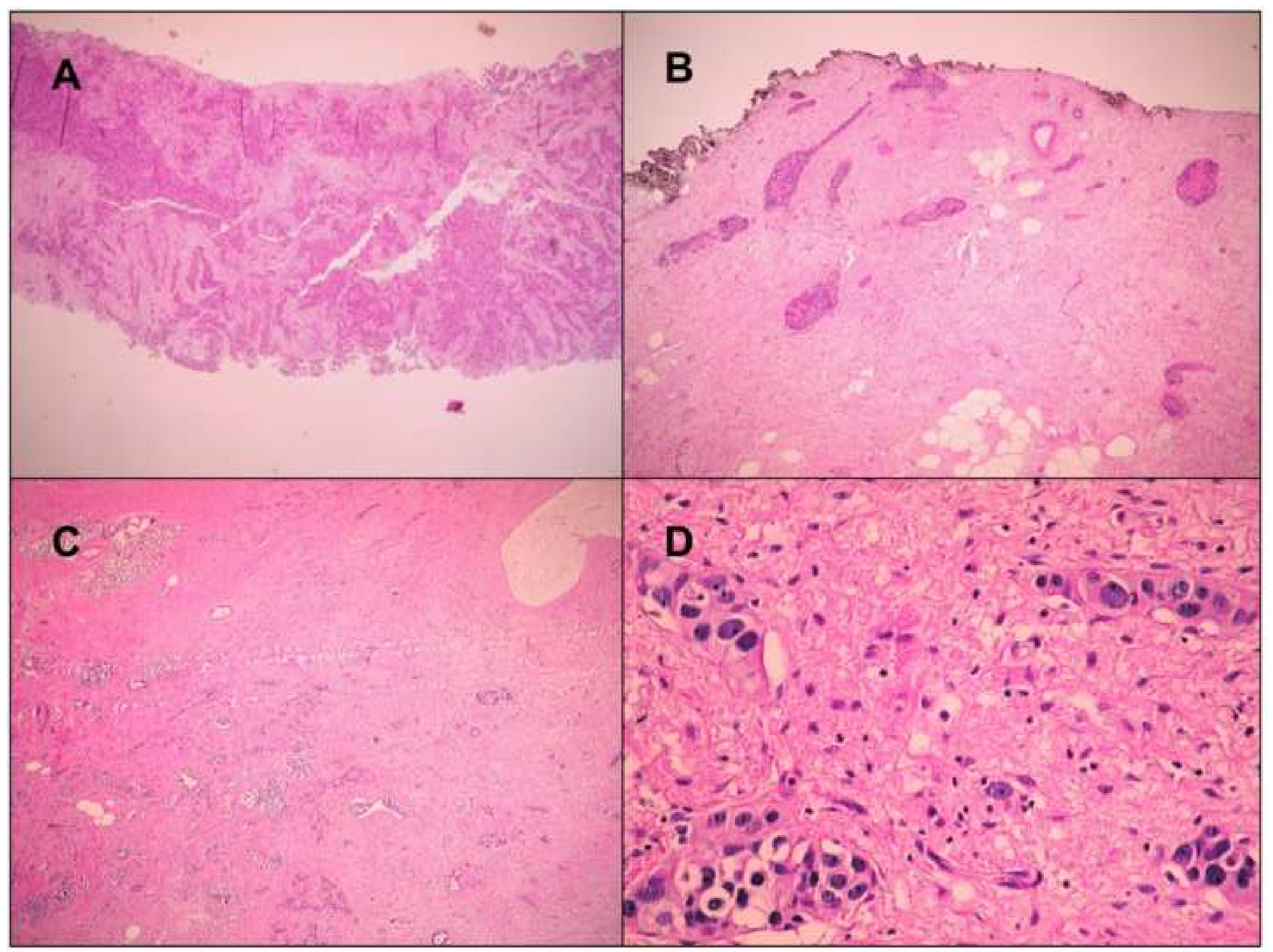




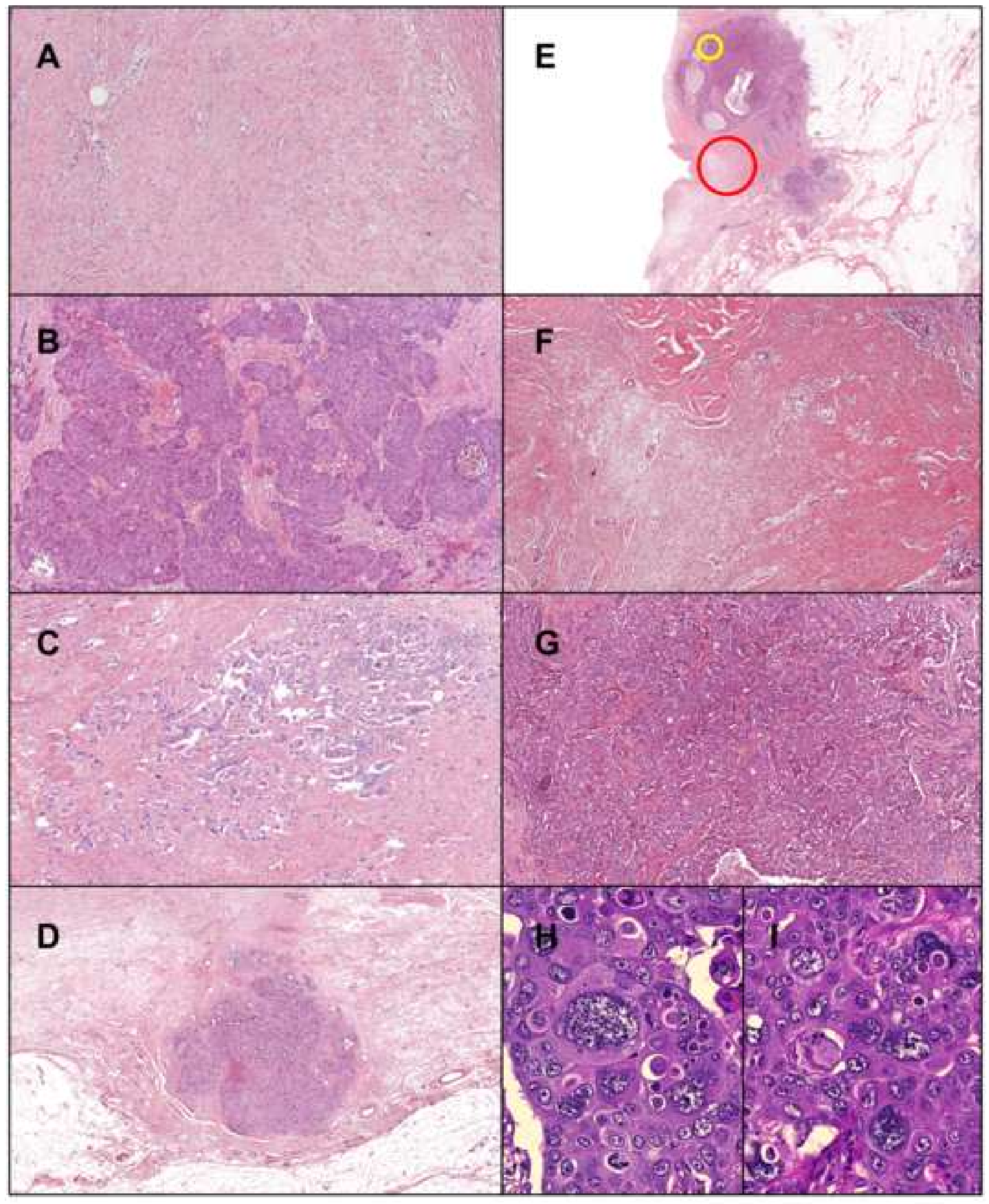

